\title{
Private Market Financing for Developing Countries
}

By a Staff Team from the Exchange and Trade Relations Department 


\title{
Private Market Financing for Developing Countries
}

\section{By a Staff Team from the Exchange and Trade Relations Department}

\author{
Alessandro Leipold \\ Mohamed A. El-Erian \\ Ajai Chopra \\ John Clark \\ Paul Mylonas \\ Louis W. Pauly
}

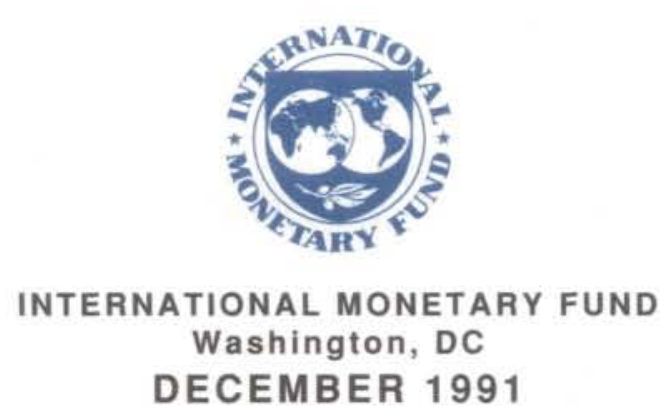

(C) International Monetary Fund. Not for Redistribution 
(c) 1991 International Monetary Fund December 1991

ISBN 1-55775-195-1

ISSN 0258-7440

Price: US $\$ 20.00$

(US\$12.00 to full-time faculty members and students at universities and colleges)

Please send orders to: International Monetary Fund, Publication Services 700 19th Street, N.W., Washington, D.C. 20431, U.S.A. Tel.: (202) 623-7430 Telefax: (202) 623-7201 


\section{Contents}

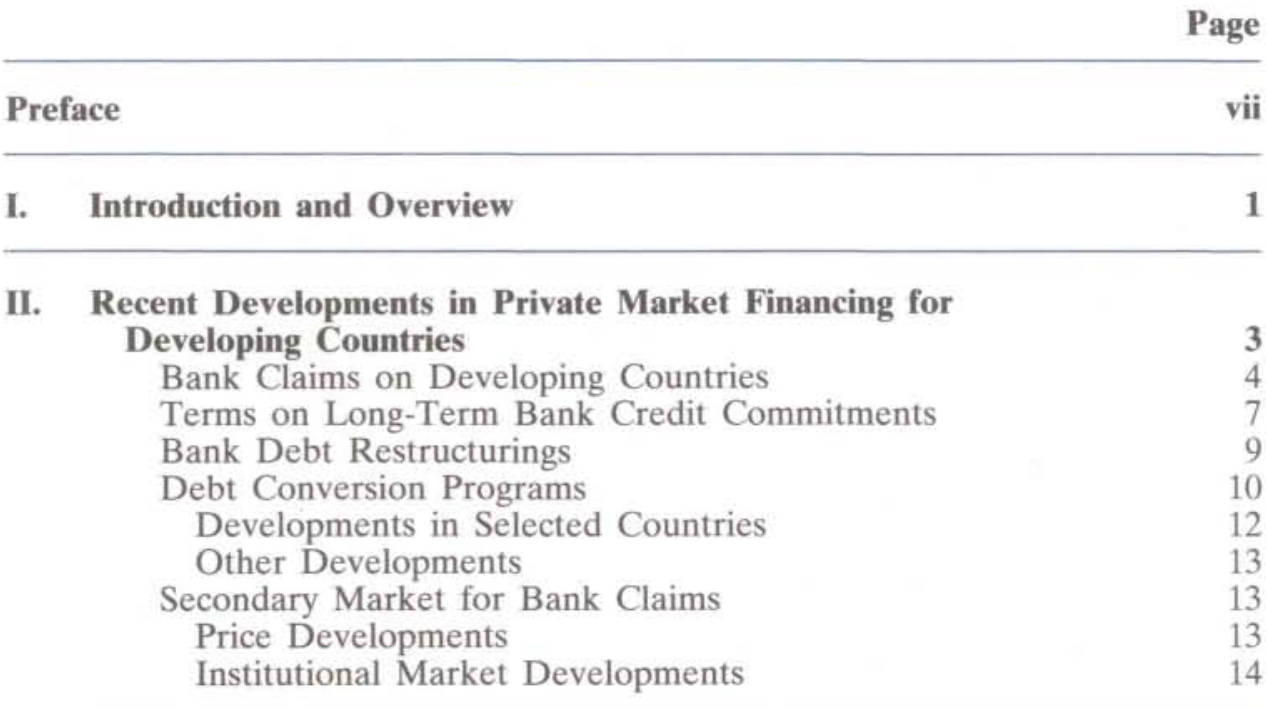

III. Restoration of Access to Voluntary Capital Market Financing 15

Recent Developments 15

The Case of an Earlier Re-Entrant 19

\begin{tabular}{ll}
\hline Instruments and Techniques & 19
\end{tabular}

Bonds versus Syndicated Loans 20

Use of Enhancements 22

Collateralization 24

Early Redemption and Conversion Options 24

Hedging Techniques $\quad 25$

Equity Issues $\quad 27$

\begin{tabular}{lr}
\hline Summary and Conclusions & 28 \\
\hline
\end{tabular}

IV. Repatriation of Flight Capital 29

Definition and Estimation Problems 29

Policies and Practices Influencing the Repatriation of Fight
Capital

\begin{tabular}{ll} 
Measures to Reverse Capital Flight & 31 \\
\hline Amnesties & 31
\end{tabular}

Capital Account Liberalization 31

Foreign-Currency-Denominated Domestic Instruments 32

Offshore Securities $\quad 32$

Debt Conversions $\quad 32$

V. Commercial Bank Debt of Low-Income Countries $\quad 34$

\begin{tabular}{ll} 
Background & 34 \\
\hline Country Circumstances & 35 \\
\hline Bank Debt Restructurings by Low-Income Countries & 36 \\
\hline Debt Swaps & 37 \\
\hline
\end{tabular}




\section{$\underline{\text { Tables }}$}

I. 1. International Lending, 1984-First Quarter 1991 3

2. Change in Cross-Border Bank Claims and Liabilities, 1985First Quarter 1991

3. Change in Cross-Border Bank Claims on Developing Countries and Areas, 1985-First Quarter 1991

4. Change in Cross-Border Bank Claims on and Liabilities to Developing Countries, by Region, 1985-First Quarter 1991

5. Long-Term Bank Credit Commitments, 1984-First Quarter 1991

6. Chronology of Bank Debt Restructurings and Bank Financial Packages, 1984-August 1991

7. Debt Conversions, 1986-First Quarter 1991

II. 8. Average Terms on International Bond Issues by Selected Developing Country Borrowers

9. Credit Ratings of Selected Developing Country Borrowers

10. Secondary Market Yields on Restructured Bank Debt and Benchmark Sovereign Bonds

\section{Appendix}

A1. Change in Interbank Claims and Liabilities, 1985-First Quarter 1991

A2. Change in Claims on Nonbanks and Liabilities to Nonbanks, 1985-First Quarter 1991

A3. Long-Term Bank Credit Commitments to Developing Countries, 1984-First Quarter 1991

A4. Bank Credit Commitments by Country of Destination, 1984-First Quarter 1991

A5. External Assets of BIS Reporting Banks by Maturity and Undisbursed Credit Commitments, December 1986-June 1990

A6. Change in Claims of U.S. Banks on Developing Countries, 1985-90

A7. U.S. Banks: Developing Country Claims Relative to Capital, 1984-90

A8. Terms of Long-Term Bank Credit Commitments, 1985-

\section{April 1991}

A9. Average Spreads on Bank Credit Commitments for Developing Countries, 1984-90

A10. Selected Developing Countries: Terms on Syndicated Bank

$\frac{\text { Credits, 1989-May } 1991}{\text { A11. Amounts of Medium- and Long-Term Bank Debt }}$ Restructured, 1985-June 1991

A12. Debt and Debt-Service Reduction in Commercial Bank Agreements, 1987-June 1991

A13. Terms of Selected Bank Debt Restructurings and Financial Packages, 1984-June 1991 
A14. Terms and Conditions of Bank Debt Restructurings and Financial Packages, 1987-June 1991

A15. Financing Instruments and Options in New Money

Packages and Restructurings of Bank Debt for Selected

Developing Countries, 1984-June 1991

69

A16. Features of Selected Debt Conversion Schemes

70

A17. International Bond Issues by Selected Developing Country Borrowers, 1989-September 1991

\section{Charts}

I. 1. Change in International Bank Claims, 1983-First Quarter 1991

2. Selected Balance Sheet Data for U.S. Banks, 1977-90

3. Terms on International Bank Lending Commitments, 1973-90

4. Secondary Market Prices for Developing Country Loans

II. 5. Mexico: Yield Spreads on Selected Debt Instruments

6. Yields on Selected Venezuelan Debt Instruments

The following symbols have been used throughout this paper:

... to indicate that data are not available;

- to indicate that the figure is zero or less than half the final digit shown, or that the item does not exist;

- between years or months (e.g., 1991-92 or January-June) to indicate the years or months covered, including the beginning and ending years or months;

I between years (e.g., 1991/92) to indicate a crop or fiscal (financial) year.

"Billion" means a thousand million.

Minor discrepancies between constituent figures and totals are due to rounding.

The term "country," as used in this paper, does not in all cases refer to a territorial entity that is a state as understood by international law and practice. The term also covers some territorial entities that are not states, but for which statistical data are maintained and provided internationally on a separate and independent basis. 
This page intentionally left blank 


\section{Preface}

This study was prepared in the Exchange and Trade Relations Department of the International Monetary Fund, under the direction of Alessandro Leipold, Chief of the Debt and Program Financing Issues Division. Its authors are Mohamed A. El-Erian, Deputy Chief of the Debt and Program Financing Issues Division, and Ajai Chopra, John Clark, and Paul Mylonas, economists in the division. The study updates information and analyses on private market financing for developing countries contained in International Capital Markets: Developments and Prospects, World Economic and Financial Surveys (Washington: International Monetary Fund, May 1991). The study was completed in September 1991 and reflects developments to that time.

The work benefited from comments by staff in other departments of the Fund and by members of the Executive Board. Opinions expressed, however, are those of the authors and do not necessarily represent the views of the Fund or its Executive Directors. Staff of the Statistics Department, particularly Richard Stillson and Dennis Jones, developed and compiled data for the study based on the Fund's international banking statistics. Louis Pauly prepared the text for publication. The authors are also grateful to Anne Jansen for excellent research assistance, and to Delrene Alvis and Ana Knowles for their valuable word processing services. David M. Cheney, of the External Relations Department, gave the manuscript a final edit and efficiently coordinated production. 
This page intentionally left blank 


\section{Introduction and Overview}

T his publication presents a survey by Fund staff of recent trends in private market financing for developing countries. ${ }^{1}$ In addition to summarizing recent developments in capital flows to developing countries through banking and securities markets, it analyzes three issues of particular interest in the debt and financing outlook for developing countries. These are the restoration of access to voluntary market financing by some developing countries; the support that can be provided to this process by the repatriation of flight capital; and the status of the commercial bank debt of low-income countries.

The onset of debt-servicing problems in the early 1980 s was associated with a virtual drying up of spontaneous (or voluntary) financing to most developing countries. Although some countriesparticularly in Asia, Eastern Europe, and North Africa-succeeded in maintaining normal market relations owing largely to the pursuit of sound economic and financial policies, most developing countries were limited to "concerted" financing in the form of principal rescheduling and interest refinancing through "new money" packages. This type of financing was broadly effective in meeting the immediate cash flow requirements of several developing countries, and in providing commercial banks with time to strengthen their balance sheets. It required, however, protracted negotiations and was associated with a further increase in developing country debt, with potentially adverse implications for private investment and the restoration of external viability.

The underlying structure of market financing for several developing countries has undergone significant change in the recent past. The change has been prompted by a recognition of the adverse impact of continued uncertainty about debt refinancing terms and of a growing debt stock on countries' development prospects, and by a concurrent reduction in banks' financial vulnerability arising from their developing country portfolios. Chapter II, which also reviews developments in the magnitude and terms of spontaneous bank financing to developing countries,

\footnotetext{
${ }^{1}$ It updates previous surveys contained in the annual editions of International Capital Markets: Developments and Prospects, also published in the IMF's World Economic and Financial Surveys series.
}

documents that the importance of principal rescheduling and concerted new money loans has declined in favor of increased emphasis on comprehensive debt relief through market-based debt- and debtservice-reduction operations. These operations played a central role in a number of comprehensive bank financing packages, such as those for Mexico and Venezuela. They have also helped expand and deepen the secondary market for developing country bank claims in terms of volume, size of investor base, and product range.

Available evidence-albeit limited to a small group of countries-suggests that, when implemented in the context of a sustained medium-term economic reform program, the comprehensive debt relief operations that have taken place have significantly improved perceptions of country transfer and credit risks. This has been reflected in favorable movements in a range of financial indicators, including lower domestic real interest rates, narrower secondary market discounts on external bank claims, and declining yields on foreign bond issues. Such movements have been associated with large private capital inflows through foreign bond and equity issues, foreign direct investments, and the repatriation of flight capital. Despite progress in some developing countries, however, several others-particularly in the low-income group-continue to face formidable obstacles in establishing access to private sources of financing and in normalizing financial relations with their commercial bank creditors.

The restoration of access to voluntary market financing is discussed in Chapter III. Following an overview of the process of market re-entry, the chapter analyzes the main instruments and techniques of re-entry, and their impact on the availability and terms of external financing for the group of developing countries concerned. The analysis highlights the sharp improvements these countries have experienced in both the volume and terms of financing received, as well as the rapidity with which market sentiments can change. While certain reentry techniques can extend the investor base and improve financing terms, the analysis shows that in an ultimately successful debt management strategy, these techniques are likely to play a marginal role, as has been the case for countries that have successfully retained spontaneous market access. 
Chapter IV examines some of the measures that countries have used to encourage the repatriation of flight capital. The analysis focuses on the extent to which capital repatriation may be influenced by such specific actions as amnesties, capital account liberalization, the availability of foreign-currencydenominated instruments, and debt conversion schemes. The review indicates that these actions have in some cases facilitated the return of flight capital, but that they cannot substitute for sound economic and financial policies.

Chapter V discusses the status of the commercial bank debt of low-income developing countries, against the background of debt relief initiatives undertaken or being considered by official bilateral creditors in support of these countries. While commercial bank debt accounts for a relatively small portion of the total external indebtedness of these countries, it often represents a sizable share of their contractual debt-servicing obligations, given its nonconcessional terms. Despite this, and notwithstanding considerable diversity among individual lowincome countries, only a very small number of such countries have completed comprehensive restructuring agreements with their bank creditors. The chapter reviews the current financial relations of these countries, including the extent to which their external indebtedness has been affected by changes in the underlying structure of international financing. 


\section{Recent Developments in Private Market Financing for Developing Countries}

$\mathbf{S}$ ince the onset of debt-servicing problems in the early 1980 s, private market claims (external bank loans and bonds) on developing countries (Table 1) have virtually stagnated. After increasing somewhat in 1989 (by $\$ 13$ billion), total claims on all developing countries (excluding offshore centers) rose by only $\$ 5$ billion in 1990 . The bulk of the movement was accounted for by cross-border bank

Table 1. International Lending, 1984-First Quarter 1991

(In billions of U.S. dollars)

\begin{tabular}{|c|c|c|c|c|c|c|c|c|}
\hline & 1984 & 1985 & 1986 & 1987 & 1988 & 1989 & 1990 & $\begin{array}{c}\text { First } \\
\text { Quarter } \\
1991\end{array}$ \\
\hline \multicolumn{9}{|c|}{$\begin{array}{l}\text { International lending through banks and } \\
\text { bond markets } \\
\text { Total }{ }^{1,2}\end{array}$} \\
\hline IMF-based & 245 & 355 & 626 & 849 & 631 & 937 & 785 & 78 \\
\hline Bond issues (net) ${ }^{3,4}$ & 62 & 77 & 87 & 51 & 77 & 97 & 43 & 26 \\
\hline \multicolumn{9}{|l|}{ Change in bank claims ${ }^{1,2}$} \\
\hline IMF-based & 182 & 278 & 539 & 798 & 554 & 840 & 742 & 52 \\
\hline Growth rate (in percent) & 7 & 10 & 17 & 20 & 11 & 15 & 12 & $\cdots$ \\
\hline \multicolumn{9}{|l|}{$\begin{array}{l}\text { International lending to industrial } \\
\text { countries } \\
\text { Total }\end{array}$} \\
\hline IMF-based & 182 & 272 & 491 & 587 & 540 & 653 & 615 & 60 \\
\hline Bond issues (net) $)^{3,4}$ & 51 & 63 & 77 & 44 & 67 & 81 & 35 & 21 \\
\hline \multicolumn{9}{|l|}{ Change in bank claims ${ }^{1}$} \\
\hline IMF-based & 131 & 209 & 414 & 543 & 473 & 572 & 580 & 39 \\
\hline Growth rate (in percent) & 8 & 13 & 21 & 21 & 14 & 15 & 13 & $\ldots$ \\
\hline \multicolumn{9}{|l|}{$\begin{array}{l}\text { International lending to developing } \\
\text { countries }\end{array}$} \\
\hline IMF-based & 14 & 8 & 4 & 23 & -3 & 13 & 5 & 13 \\
\hline Bond issues (net) $)^{3,4}$ & 3 & 4 & 2 & 1 & 2 & 2 & 1 & - \\
\hline \multicolumn{9}{|l|}{ Change in bank claims ${ }^{1}$} \\
\hline IMF-based & 11 & 4 & 2 & 22 & -5 & 11 & 4 & 13 \\
\hline Growth rate (in percent) & 2 & 1 & - & 4 & -1 & 2 & 1 & $\cdots$ \\
\hline \multicolumn{9}{|l|}{ Memorandum items } \\
\hline $\begin{array}{l}\text { Total gross bond issues } \\
\text { Of which: }\end{array}$ & 110 & 168 & 227 & 181 & 227 & 256 & 229 & 80 \\
\hline Industrial countries & 91 & 138 & 201 & 156 & 198 & 224 & 189 & 65 \\
\hline Developing countries 5 & 4 & 8 & 4 & 4 & 6 & 5 & 5 & 2 \\
\hline \multicolumn{9}{|c|}{$\begin{array}{l}\text { Sources: Bank for International Settlements (BIS); Organization for Economic Cooperation and Development (OECD); International Monetary } \\
\text { Fund, International Financial Statistics; and IMF staff estimates. } \\
\text { IIMF-based data on cross-border changes in bank claims are derived from the IMF's international banking statistics (IBS) (cross-border interbank } \\
\text { accounts by residence of borrowing bank plus international bank credits to nonbanks by residence of borrower), excluding changes attributed to } \\
\text { exchange rate movements. The data derive cross-border interbank positions from the regular money and banking data supplied by member countries. } \\
\text { 'Total changes in bank claims include offshore centers, international organizations, and other non-IMF members, as well as industrial and } \\
\text { developing countries. } \\
{ }^{3} \text { Estimates based on BIS and OECD data. } \\
\text { }{ }^{4} \text { Net of redemption and repurchases, and of double counting, that is, bonds taken up by the reporting banks to the extent that they are included in } \\
\text { the banking statistics as claims on nonresidents and bonds issued by the reporting banks mainly for underpinning their international lending activity. } \\
{ }^{5} \text { Excludes the seven offshore centers (The Bahamas, Bahrain, the Cayman Islands, Hong Kong, the Netherlands Antilles, Panama, and Singapore). }\end{array}$} \\
\hline
\end{tabular}


claims. The increase in such claims fell from almost $\$ 11$ billion in 1989 to $\$ 3^{1 / 2}$ billion in 1990 (a growth rate of some 1 percent), as debt reduction operations by a number of developing countries largely offset both the accumulation of interest arrears by several others and continued voluntary lending to developing countries in Asia. A sharp slowdown in debt reduction activity in early 1991-combined with continued interest arrears and further strong lending to Asian countries-led to a relatively pronounced increase in bank claims on developing countries in the first quarter of the year; quarterly data often show sharp swings, however, and the underlying trend continues to be one of extreme caution in bank lending to developing countries.

Bond issues by developing countries, as reported by the Organization for Economic Cooperation and Development (OECD), amounted to $\$ 1$ billion in 1990. Market-based data with more comprehensive coverage (including fuller reporting of private placements) point, however, to a higher figure for total bond issuance-some $\$ 3$ billion-largely because of placements by Mexican borrowers (see Chapter III). Preliminary market-based data point to a further expansion of developing country bond placements during 1991. Over the last two years, these developments were accompanied by further changes in the underlying structure of developing country financing. These included a sharp reduction in the importance of principal rescheduling and concerted new money packages, more widespread use of marketbased debt- and debt-service reduction operations, and the restoration of access to voluntary capital market flows by some countries with recent debtservicing problems.

\section{Bank Claims on Developing Countries $^{2}$}

International banking activity in developing countries during 1990 was dominated by a $\$ 28$ billion fall in claims on the 15 heavily indebted countries (Table 2 and Chart 1). The bulk of this decline was accounted for by Mexico and Venezuela, which finalized comprehensive restructuring packages incorporating bank debt reduction elements during the year (Table 3). At the same time, the build-up of interest arrears by Argentina was more than offset by the elimination of debt through debt-equity swaps implemented in connection with that coun-

\footnotetext{
${ }^{2}$ Based on data compiled for the Fund's international banking statistics. Reported changes in bank claims reflect, in some cases, adjustments to banks' balance sheets that are not directly related to flows. These include debt write-offs and conversions, capitalization of accumulated interest arrears, and exercises of official guarantees.
}

\section{Chart 1. Change in International Bank Claims, 1983-First Quarter 19911 (In billions of U.S. dollars)}

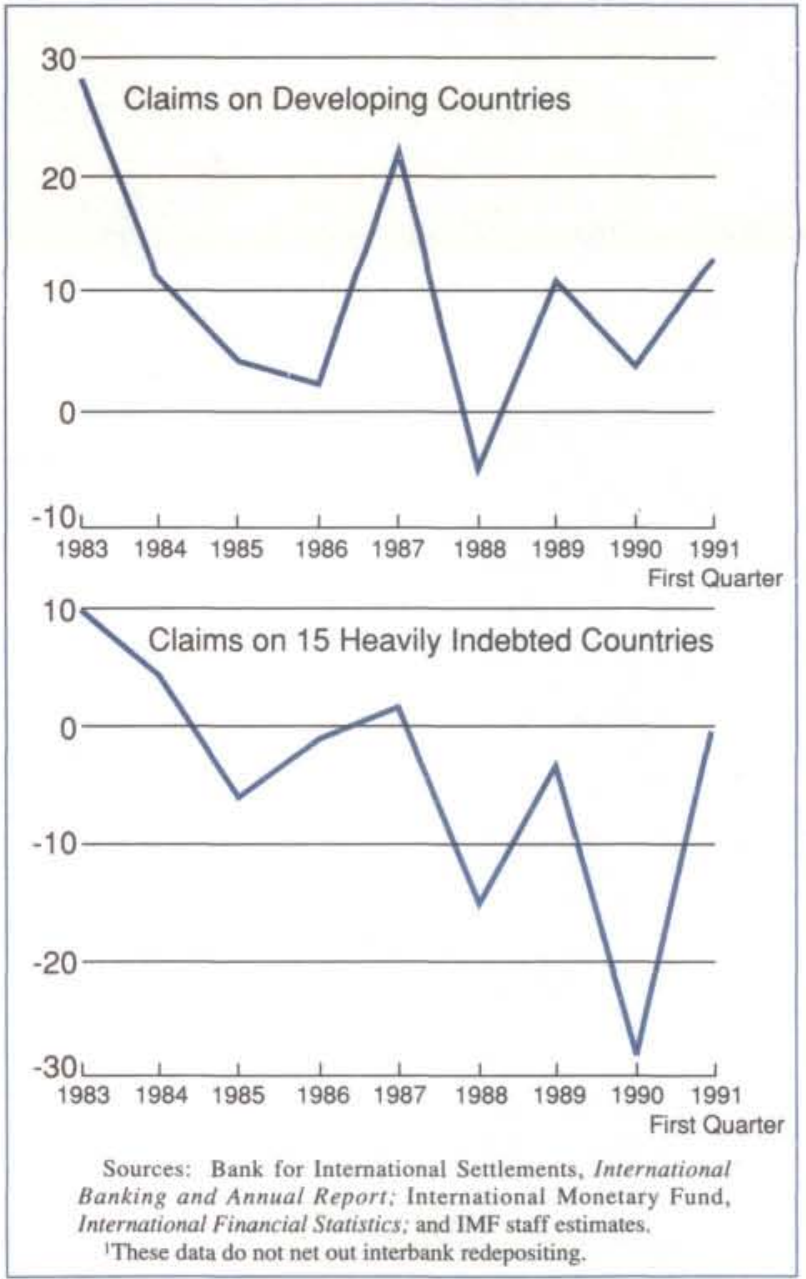

try's privatization program. A further reduction in bank claims resulted from ongoing debt conversion programs in Chile, the Philippines, and Yugoslavia (totaling $\$ 2$ billion); in contrast, bank claims on Brazil rose by $\$ 3$ billion as interest arrears continued to accumulate.

Most geographical regions-except Asia and, to a lesser extent, Europe-recorded a decline in bank claims on developing countries during 1990 (Tables 4, A1, and A2). Claims on Western Hemisphere developing countries fell by $\$ 21$ billion; in the Middle East, uncertainties associated with the military conflict contributed to a $\$ 1 \frac{1}{2}$ billion decline in claims (compared with average annual increases of almost $\$ 5$ billion in the previous two years); and African countries' indebtedness to commercial banks fell by $\$ 600$ million, the fifth consecutive annual decline. By contrast, bank claims on developing countries in 
Table 2. Change in Cross-Border Bank Claims and Liabilities, 1985-First Quarter 19911 (In billions of U.S. dollars)

\begin{tabular}{|c|c|c|c|c|c|c|c|}
\hline & 1985 & 1986 & 1987 & 1988 & 1989 & 1990 & $\begin{array}{c}\text { First } \\
\text { Quarter } \\
1991\end{array}$ \\
\hline Total change in claims ${ }^{2}$ & 278 & 539 & 798 & 554 & 840 & 742 & 52 \\
\hline Industrial countries & 209 & 414 & 543 & 473 & 572 & 580 & 39 \\
\hline \multicolumn{8}{|l|}{ Of which: } \\
\hline United States & 55 & 93 & 106 & 108 & 93 & 65 & -10 \\
\hline Japan & 40 & 154 & 223 & 203 & 172 & 101 & -53 \\
\hline Developing countries ${ }^{3}$ & 4 & 2 & 22 & -5 & 11 & 4 & 13 \\
\hline Offshore centers ${ }^{4}$ & 28 & 86 & 164 & 85 & 181 & 128 & -22 \\
\hline Other transactors ${ }^{5}$ & 10 & -7 & 17 & 7 & 34 & -11 & - \\
\hline Unallocated (nonbanks) ${ }^{6}$ & 26 & 43 & 51 & -7 & 43 & 41 & 21 \\
\hline \multicolumn{8}{|l|}{ Memorandum items } \\
\hline Capital importing developing countries ${ }^{3,7}$ & 5 & 3 & 21 & -9 & 6 & 5 & 11 \\
\hline Non-oil developing countries ${ }^{3.8}$ & 3 & 3 & 22 & -10 & 7 & 7 & 15 \\
\hline Fifteen heavily indebted countries & -6 & -1 & 2 & -15 & -3 & -28 & 1 \\
\hline Total change in liabilities ${ }^{9}$ & 301 & 584 & 760 & 540 & 812 & 645 & -48 \\
\hline Industrial countries & 194 & 424 & 492 & 377 & 571 & 499 & 14 \\
\hline \multicolumn{8}{|l|}{ Of which: } \\
\hline United States & 22 & 82 & 57 & 84 & 67 & 24 & -13 \\
\hline Japan & 42 & 114 & 146 & 148 & 138 & 55 & -41 \\
\hline Developing countries $^{3}$ & 23 & -7 & 48 & 37 & 74 & 72 & -7 \\
\hline Offshore centers ${ }^{4}$ & 46 & 130 & 144 & 100 & 148 & 43 & -36 \\
\hline Other transactors 5 & 8 & -6 & 18 & 6 & 13 & -19 & -2 \\
\hline Unallocated (nonbanks) ${ }^{6}$ & 30 & 42 & 58 & 21 & -6 & 50 & -17 \\
\hline \multicolumn{8}{|l|}{ Memorandum items } \\
\hline Capital importing developing countries ${ }^{3,7}$ & 21 & 8 & 36 & 25 & 59 & 70 & -3 \\
\hline Non-oil developing countries ${ }^{3,8}$ & 16 & 16 & 36 & 25 & 53 & 60 & -5 \\
\hline Fifteen heavily indebted countries & 5 & -4 & 10 & 5 & 17 & 21 & -1 \\
\hline Change in total net claims ${ }^{10}$ & -23 & -45 & 38 & 14 & 28 & 96 & 100 \\
\hline Industrial countries & 15 & -11 & 51 & 96 & 1 & 81 & 25 \\
\hline \multicolumn{8}{|l|}{ Of which: } \\
\hline United States & 33 & 12 & 49 & 24 & 26 & 41 & 3 \\
\hline Japan & -2 & 40 & 77 & 55 & 34 & 46 & -12 \\
\hline Developing countries $^{3}$ & -19 & 9 & -26 & -41 & -63 & -68 & 20 \\
\hline Offshore centers ${ }^{4}$ & -17 & -44 & 20 & -16 & 32 & 85 & 15 \\
\hline Other transactors 5 & 2 & -1 & - & 2 & 21 & 8 & 2 \\
\hline Unallocated (nonbanks) ${ }^{6}$ & -3 & 1 & -7 & -27 & 37 & -9 & 38 \\
\hline \multicolumn{8}{|l|}{ Memorandum items } \\
\hline Capital importing developing countries ${ }^{3.7}$ & -16 & -5 & -15 & -34 & -53 & -65 & 14 \\
\hline Non-oil developing countries 3,8 & -13 & -13 & -15 & -35 & -47 & -53 & 20 \\
\hline Fifteen heavily indebted countries & -10 & 3 & -7 & -20 & -20 & -49 & 2 \\
\hline
\end{tabular}

Sources: International Monetary Fund, International Financial Statistics (IFS); and IMF staff estimates.

'Data on changes in bank claims and liabilities are derived from stock data on the reporting countries' liabilities and assets, excluding changes attributed to exchange rate movements.

${ }^{2}$ As measured by differences in the outstanding liabilities of borrowing countries, defined as cross-border interbank accounts by residence of borrowing bank plus international bank credits to nonbanks by residence of borrower.

${ }^{3}$ Excluding offshore centers.

${ }^{4}$ The Bahamas, Bahrain, the Cayman Islands. Hong Kong, the Netherlands Antilles, Panama, and Singapore.

sTransactors included in IFS measures for the world, to enhance global symmetry, but excluded from IFS measures for "All Countries." The data comprise changes in identified cross-border bank accounts of European developing economies (excluding IMF members) and of international organizations.

6The difference between the amount that countries report as their banks' positions with nonresident nonbanks in their monetary statistics and the amounts that banks in major financial centers report as their positions with nonbanks in each country.

${ }^{7}$ All developing countries except the eight Middle Eastern oil exporters (the Islamic Republic of Iran, Iraq, Kuwait, the Libyan Arab Jamahiriya, Oman, Qatar, Saudi Arabia, and the United Arab Emirates) for which external debt statistics are not available or are small in relation to external assets,

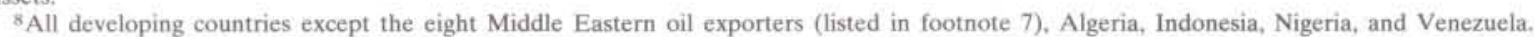

${ }^{9}$ As measured by differences in the outstanding assets of depositing countries, defined as cross-border interbank accounts by residence of lending bank plus international bank deposits of nonbanks by residence of depositor.

10Difference between changes in bank claims and liabilities. 
Table 3. Change in Cross-Border Bank Claims on Developing Countries and Areas, 1985-First Quarter 19911,2 (In billions of U.S. dollars)

\begin{tabular}{|c|c|c|c|c|c|c|c|}
\hline & 1985 & 1986 & 1987 & 1988 & 1989 & 1990 & $\begin{array}{c}\text { First } \\
\text { Quarter } \\
1991\end{array}$ \\
\hline Developing countries and areas & 3.8 & 2.5 & 22.0 & -4.6 & 10.9 & 3.6 & 13.0 \\
\hline Growth rate (in percent) & 1 & - & 4 & -1 & 2 & 1 & $\cdots$ \\
\hline & 1.0 & -1.1 & \multicolumn{2}{|c|}{ Of which: } & -1.8 & -0.6 & -1.5 \\
\hline Algeria & 1.9 & 1.0 & -0.4 & 0.2 & -0.8 & -1.0 & -0.9 \\
\hline Côte d'Ivoire & 0.1 & 0.1 & -0.1 & -0.1 & -0.2 & -0.4 & -0.4 \\
\hline Morocco & 0.1 & - & - & -0.3 & 0.1 & -0.1 & -0.1 \\
\hline Nigeria & -1.3 & 0.4 & -0.7 & -0.5 & -0.9 & -0.8 & - \\
\hline South Africa & -0.3 & -2.1 & -0.1 & -1.2 & -0.9 & -0.4 & 0.8 \\
\hline Asia & 6.7 & 4.9 & 15.0 & 3.8 & 4.4 & 23.1 & 9.4 \\
\hline \multicolumn{8}{|l|}{ Of which: } \\
\hline China & 4.9 & 0.7 & 4.8 & 7.1 & -0.5 & 7.5 & 0.7 \\
\hline India & 1.7 & 0.3 & 2.6 & 1.0 & 1.0 & -0.5 & 0.6 \\
\hline Indonesia & $\overline{2}$ & 0.6 & 0.9 & 0.8 & 1.7 & 7.8 & 1.7 \\
\hline Korea & 2.3 & -2.3 & -5.6 & -1.8 & 1.2 & 4.1 & 2.8 \\
\hline Malaysia & -1.4 & -0.5 & -1.9 & -1.5 & -0.3 & -0.3 & -0.4 \\
\hline Philippines & -0.5 & -0.1 & 0.1 & -1.1 & -1.5 & -1.0 & 0.3 \\
\hline Taiwan Province of China & - & 7.1 & 13.3 & -1.7 & 0.2 & 0.7 & 1.4 \\
\hline \multirow{2}{*}{\multicolumn{8}{|c|}{ Of which: }} \\
\hline Hungary & 2.3 & 2.0 & 0.7 & 0.7 & & & \\
\hline Poland & -1.4 & -0.9 & -0.5 & -0.7 & -0.4 & 1.0 & 0.4 \\
\hline Turkey & 0.5 & 1.5 & 1.5 & -0.1 & 0.2 & 3.3 & 1.3 \\
\hline Yugoslavia & 0.2 & -0.9 & -0.9 & -0.7 & -1.4 & -0.9 & -0.5 \\
\hline \multirow{2}{*}{\multicolumn{8}{|c|}{$\begin{array}{l}\text { Middle East } \\
\text { Of which: }\end{array}$}} \\
\hline Egypt & & & & & & & \\
\hline Israel & -0.5 & -1.2 & -0.7 & -0.1 & -1.3 & - & 0.2 \\
\hline \multirow{2}{*}{\multicolumn{8}{|c|}{$\begin{array}{l}\text { Western Hemisphere } \\
\text { Of which: }\end{array}$}} \\
\hline $\begin{array}{l}\text { Or which: } \\
\text { Argentina }\end{array}$ & 0.6 & 1.3 & 0.8 & 0.4 & & & \\
\hline Brazil & -4.5 & - & 3.9 & -5.5 & 2.6 & 3.0 & 0.8 \\
\hline Chile & 0.2 & -1.0 & -1.4 & -1.8 & -2.2 & -0.1 & -0.2 \\
\hline Colombia & - & 0.4 & -0.5 & 0.7 & -0.2 & 0.1 & -0.1 \\
\hline Ecuador & 0.2 & 0.3 & 0.2 & -0.2 & -0.3 & -0.6 & -0.1 \\
\hline Mexico & -0.8 & -0.8 & 1.3 & -6.3 & -0.2 & -18.5 & 1.2 \\
\hline Venezuela & 0.5 & -1.1 & -0.3 & 0.6 & 0.2 & -7.4 & -1.0 \\
\hline \multicolumn{8}{|l|}{ Memorandum items } \\
\hline Fifteen heavily indebted countries & -5.5 & -1.4 & 2.4 & -14.6 & -2.9 & -28.0 & 0.8 \\
\hline $\begin{array}{l}\text { Countries experiencing } \\
\text { debt-servicing problems }\end{array}$ & -7.5 & -6.4 & 0.9 & -16.5 & -4.6 & -22.7 & 0.1 \\
\hline Gross concerted lending & & & & & & & \\
\hline disbursements $^{3}$ & 5.4 & 3.3 & 5.7 & 6.0 & 0.6 & 1.8 & - \\
\hline Gross bond issues & 8.1 & 4.2 & 3.7 & 6.0 & 4.5 & 5.1 & 1.5 \\
\hline \multicolumn{8}{|c|}{$\begin{array}{l}\text { Sources: Bank for International Settlements (BIS); Organization for Economic Cooperation and Development; International Monetary Fund, } \\
\text { International Financial Statistics (IFS); and IMF staff estimates. } \\
\text { 'IMF-based data on cross-border lending by banks are derived from the IMF's international banking statistics (IBS) (cross-border interbank } \\
\text { accounts by residence of borrowing bank pius international bank credits to nonbanks by residence of borrower), excluding changes attributed to } \\
\text { exchange rate movements. The IMF data derive cross-border interbank positions from the regular money and banking data supplied by member } \\
\text { countries, while the IMF analysis of transactions with nonbanks is based on data from geographical breakdowns provided by the BIS reporting } \\
\text { countries and additional banking centers. } \\
\text { }{ }^{2} \text { Excluding the seven offshore centers (The Bahamas, Bahrain, the Cayman Islands, Hong Kong, the Netherlands Antilles, Panama, and Singapore). } \\
{ }^{3} \text { Excluding bridge loans. }\end{array}$} \\
\hline
\end{tabular}


Table 4. Change in Cross-Border Bank Claims on and Liabilities to Developing Countries, by Region, 1985-First Quarter 1991

(In billions of U.S. dollars)

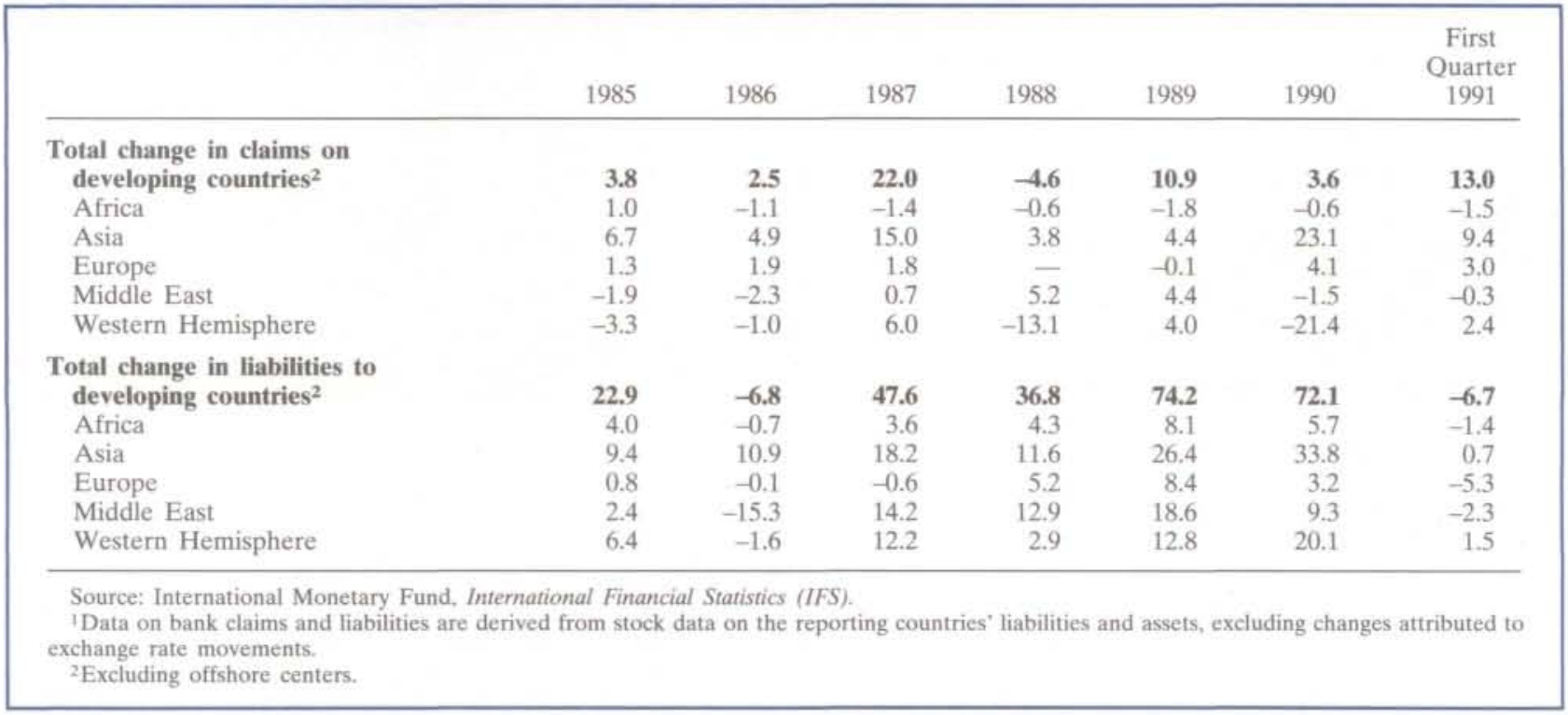

Europe increased by approximately $\$ 4$ billion. This growth reflected, among other things, increased net borrowings by Turkey (over $\$ 3$ billion) and the accumulation of interest arrears by Poland (approximately $\$ 1$ billion), which more than offset the impact of debt conversions in Yugoslavia and continued bank reluctance to lend to countries in Eastern Europe. Asia accounted for the largest rise in bank claims ( $\$ 23$ billion). This reflected, in part, larger net lending to Indonesia ( $\$ 8$ billion), China ( $\$ 71 / 2$ billion), and Korea ( $\$ 4$ billion). Claims on the Philippines and India declined by $\$ 1^{1 / 2}$ billion.

These changes in bank claims were accompanied by a further evolution in the structure of new gross lending to developing countries. This was most apparent in the data reported by banks on their longterm loan commitments. While the magnitude of total international bank credit commitments to developing countries in 1989 and 1990 was broadly similar-at about $\$ 19$ billion (Table 5) - the share of concerted new money loans fell further (from a peak of 33 percent in 1987 to 7 percent in 1990). This trend continued in the first quarter of 1991, with spontaneous credit accounting for all new long-term commitments by banks (Tables A3 and A4).

In terms of overall bank balance sheets, available data point to a further fall in exposure to developing countries. ${ }^{3}$ Banks reporting to the Bank for Interna-

${ }^{3}$ After taking into account claims held by banks but guaranteed by other agencies. tional Settlements (BIS) experienced a 5 percent reduction in total nominal exposure on developing countries between the end of December 1989 and the end of June 1990, the latest period for which comprehensive data are available (Table A5). In the case of U.S. banks, reported claims fell by 13 percent in 1990 (Table A6). This was reflected in a further decline in the importance of developing country claims relative to other balance sheet items. Specifically, the ratio of capital to claims on developing countries continued to increase, reaching 232 percent at the end of 1990-almost twice the end-1987 level (Table A7 and Chart 2). Moreover, the share of external claims on developing countries in total bank assets declined further to an estimated 3.7 percent.

\section{Terms on Long-Term Bank Credit Commitments}

Average spreads on all bank loan commitments to developing countries (spontaneous and concerted facilities) have declined substantially since 1983 , reaching 68 basis points over LIBOR in 1989 and falling to 60 basis points in 1990 (Table A8 and Chart 3). This tendency was reversed in the first four months of 1991 as a result of the absence of concerted new money commitments (which have carried relatively lower spreads), combined with higher spreads on spontaneous credits to several countries that have not restructured their debt and a change in 
Table 5. Long-Term Bank Credit Commitments, 1984-First Quarter 1991

(In billions of U.S. dollars)

\begin{tabular}{|c|c|c|c|c|c|c|c|c|c|}
\hline & \multirow[b]{2}{*}{1984} & \multirow[b]{2}{*}{1985} & \multirow[b]{2}{*}{1986} & \multirow[b]{2}{*}{1987} & \multirow[b]{2}{*}{1988} & \multirow[b]{2}{*}{1989} & \multirow[b]{2}{*}{1990} & \multicolumn{2}{|c|}{ First Quarter } \\
\hline & & & & & & & & 1990 & 1991 \\
\hline & \multicolumn{9}{|c|}{ (Long-term external credit commitments) } \\
\hline Industrial countries & 32.0 & 32.4 & 40.5 & 54.3 & 95.7 & 97.6 & 90.2 & 18.2 & 11.6 \\
\hline Seven major & 18.2 & 21.2 & 24.3 & 41.3 & 78.5 & 75.5 & 66.7 & 10.0 & 6.9 \\
\hline Other & 13.8 & 11.2 & 16.2 & 13.0 & 17.2 & 22.1 & 23.5 & 8.2 & 4.7 \\
\hline Developing countries ${ }^{1}$ & 29.2 & 16.0 & 22.8 & 16.4 & 17.5 & 18.2 & 17.8 & 3.4 & 2.6 \\
\hline Capital importing 1 & 28.1 & 14.4 & 21.4 & 16.3 & 17.2 & 16.8 & 17.8 & 3.4 & 2.6 \\
\hline Africa & 0.6 & 1.5 & 1.8 & 0.7 & 0.6 & 0.5 & 0.6 & 0.1 & - \\
\hline Asia & 9.4 & 7.5 & 8.2 & 8.5 & 7.8 & 8.9 & 10.7 & 1.9 & 2.6 \\
\hline Europe & 1.6 & 2.8 & 2.8 & 4.1 & 2.2 & 2.7 & 1.7 & - & - \\
\hline Middle East & 0.4 & 0.3 & 0.1 & 0.3 & 0.2 & 0.7 & 0.1 & - & - \\
\hline Western Hemisphere & 16.1 & 2.4 & 8.5 & 2.7 & 6.4 & 4.1 & 4.8 & 1.4 & - \\
\hline Offshore banking centers & 0.9 & 0.4 & 0.7 & 0.3 & 0.4 & 2.4 & 3.0 & 0.2 & 0.7 \\
\hline Other countries n.i.e. & 1.9 & 3.5 & 2.1 & 1.5 & 2.5 & 1.5 & 3.0 & - & - \\
\hline \multicolumn{10}{|l|}{ International organizations } \\
\hline and unallocated & 3.5 & 4.0 & 5.2 & 11.7 & 10.0 & 3.3 & 7.3 & 0.5 & 0.9 \\
\hline \multirow[t]{2}{*}{ Total } & 67.5 & 56.3 & 71.3 & 84.3 & 126.1 & 123.0 & 121.3 & 22.3 & 15.8 \\
\hline & \multicolumn{9}{|c|}{ (Other international long-term bank facilities) } \\
\hline Industrial countries & 48.1 & 44.5 & 25.8 & 27.6 & 14.8 & 7.0 & 4.6 & 1.3 & 1.0 \\
\hline Seven major & 33.9 & 33.6 & 14.4 & 20.0 & 11.3 & 3.7 & 0.6 & 0.1 & - \\
\hline Other & 14.2 & 10.9 & 11.4 & 7.6 & 3.4 & 3.3 & 4.0 & 1.2 & 1.0 \\
\hline Developing countries $^{1}$ & 6.2 & 2.1 & 3.1 & 1.3 & 1.4 & 0.7 & 1.4 & 0.3 & 0.2 \\
\hline Capital importing1 & 5.9 & 1.8 & 3.1 & 1.3 & 1.4 & 0.7 & 1.4 & 0.3 & 0.2 \\
\hline Africa & 0.2 & - & - & - & 0.2 & - & 0.2 & 0.1 & - \\
\hline Asia & 1.1 & 1.3 & 2.0 & 0.9 & 0.8 & 0.4 & 1.2 & 0.2 & 0.2 \\
\hline Europe & 0.4 & 0.3 & 0.9 & 0.3 & 0.4 & 0.1 & - & - & - \\
\hline Middle East & - & - & - & - & - & - & - & - & - \\
\hline Western Hemisphere & 4.3 & 0.1 & 0.1 & - & - & 0.2 & - & - & - \\
\hline Offshore banking centers & 0.4 & 0.2 & 0.2 & 0.3 & 0.2 & 0.3 & 0.3 & - & 0.1 \\
\hline Other countries n.i.e. & - & - & 0.5 & 0.2 & 0.2 & 0.1 & - & - & - \\
\hline International organizations & & & & & & & & & \\
\hline and unallocated & 0.6 & 2.1 & 0.3 & 1.7 & - & 0.2 & - & - & - \\
\hline \multirow[t]{2}{*}{ Total } & 55.3 & 48.9 & 30.0 & 31.2 & 16.6 & 8.4 & 6.3 & 1.6 & 1.3 \\
\hline & \multicolumn{9}{|c|}{ (Total international commitments) } \\
\hline Industrial countries & 80.1 & 76.9 & 66.3 & 81.9 & 110.5 & 104.6 & 94.8 & 19.5 & 12.6 \\
\hline Seven major & 52.1 & 54.8 & 38.7 & 61.3 & 89.8 & 79.2 & 67.3 & 10.1 & 6.9 \\
\hline Other & 28.0 & 22.1 & 27.6 & 20.6 & 20.7 & 25.4 & 27.5 & 9.4 & 5.7 \\
\hline Developing countries $^{1}$ & 35.4 & 18.1 & 25.9 & 17.7 & 18.9 & 18.9 & 19.2 & 3.7 & 2.8 \\
\hline Capital importing 1 & 34.0 & 16.2 & 24.5 & 17.6 & 18.6 & 17.5 & 19.2 & 3.7 & 2.8 \\
\hline Africa & 0.8 & 1.5 & 1.8 & 0.7 & 0.8 & 0.5 & 0.8 & 0.2 & - \\
\hline Asia & 10.5 & 8.8 & 10.2 & 9.4 & 8.6 & 9.3 & 11.9 & 2.1 & 2.8 \\
\hline Europe & 2.0 & 3.1 & 3.7 & 4.4 & 2.3 & 2.8 & 1.7 & - & - \\
\hline Middle East & 0.4 & 0.3 & 0.1 & 0.3 & 0.2 & 0.7 & 0.1 & - & - \\
\hline Western Hemisphere & 20.4 & 2.4 & 8.6 & 2.7 & 6.4 & 4.3 & 4.8 & 1.4 & - \\
\hline Offshore banking centers & 1.4 & 0.6 & 0.9 & 0.6 & 0.6 & 2.7 & 3.3 & 0.2 & 0.8 \\
\hline Other countries n.i.e. & 1.9 & 3.5 & 2.6 & 1.7 & 2.7 & 1.6 & 3.0 & - & - \\
\hline \multicolumn{10}{|l|}{ International organizations } \\
\hline and unallocated & 4.1 & 6.2 & 5.5 & 13.4 & 10.0 & 3.5 & 7.3 & 0.5 & 0.9 \\
\hline Total & 122.7 & 105.1 & 101.3 & 115.5 & 142.7 & 131.4 & 127.6 & 23.9 & 17.1 \\
\hline
\end{tabular}

the composition of borrowers. The spreads on both concerted new money commitments and rescheduled principal obligations fell substantially in the mid-1980s and have since then remained in a range between 80 and 95 basis points (Table A9). Average spreads on spontaneous commitments amounted to 60 basis points in 1990 , broadly the level that prevailed in the mid-1980s. Annual fluctuations in spreads have tended to reflect, to a large extent, changes in the composition of borrowers, as well as 


\section{Chart 2. Selected Balance Sheet Data for U.S. Banks, 1977-1990 \\ (In percent)}

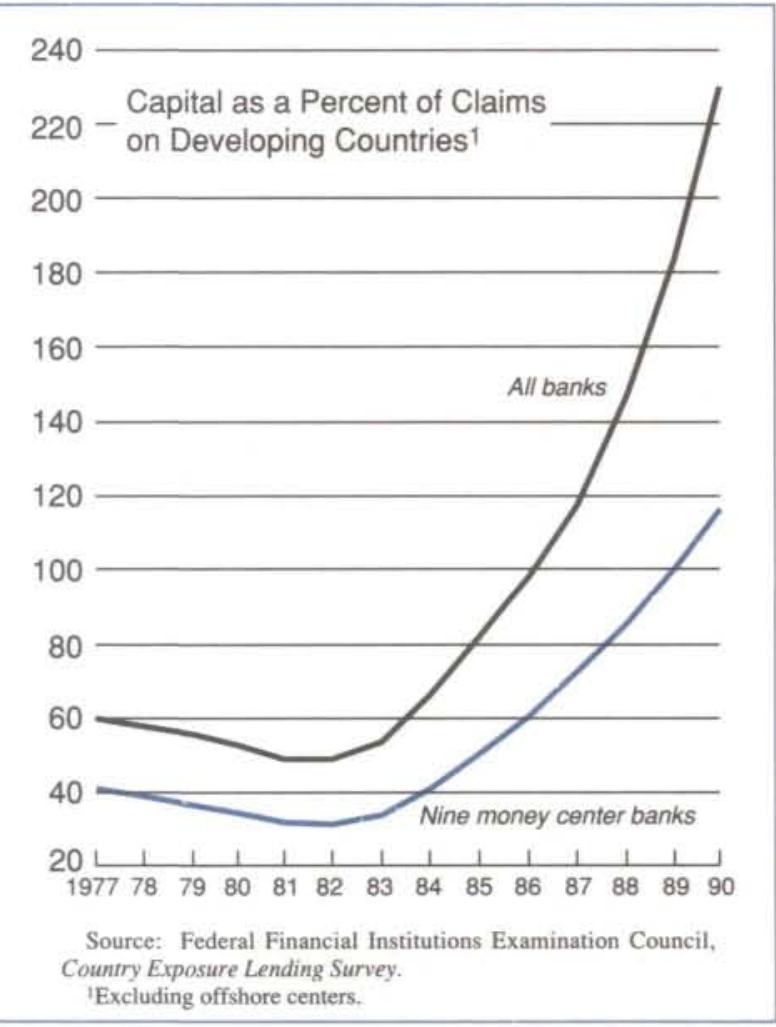

in the structure of loans (particularly the degree of securitization). Preliminary indications are that several developing countries, including those that have regularly serviced their debts and not resorted to commercial bank debt restructurings, experienced an increase in spreads early in 1991 (Table A10).

The average overall maturity of long-term bank credit commitments to developing countries rose from 7.3 years in 1989 to 8.6 years in 1990. A further increase to 8.8 years was recorded for the first four months of 1991. These developments were the result of changes in maturity terms on spontaneous lending; the terms on concerted financing remained broadly unchanged, with the largest portion of rescheduled principal carrying a 15 -year term.

\section{Bank Debt Restructurings}

Apart from the agreements with Niger and Uruguay, ${ }^{4}$ no comprehensive debt restructuring agreements were finalized in the first three quarters of

${ }^{4}$ Described in IMF (1991).
1991 (Tables 6 and A11-A15 provide details on commercial bank debt restructuring agreements). Two preliminary agreements, however, were concluded with Nigeria ${ }^{5}$ and the Philippines. ${ }^{6}$ Several other developing countries are in the process of negotiating packages with their commercial bank creditors. These include, but are not limited to, Argentina, Bolivia, Brazil, Bulgaria, Cameroon, Côte d'Ivoire, the Dominican Republic, Ecuador, Gabon, Guyana, Honduras, Jordan, Mozambique, and Poland. In some of these countries-particularly the low-income and smaller middle-income economies-progress has been relatively slow in reaching understandings on restructuring terms.

While the group of countries negotiating bank packages is relatively heterogeneous in terms of commercial bank relations (even if an income-based focus is adopted, as illustrated in Chapter V), three main trends may be highlighted:

(1) Banks appear to be insisting more firmly on addressing interest arrears problems, particularly of middle-income developing countries, prior to negotiation on comprehensive debt restructuring. In the case of Brazil, this was reflected in an agreement reached in May 1991, which included a partial payment of accumulated interest arrears and conversion of the remaining portion into bonds. The agreement provides for cash payment of 25 percent of the arrears accumulated by the end of 1990 , with a cap of $\$ 2$ billion on such cash payments. A portion of the cash payment was made up front at the time of agreement in principle on the term sheet. The remaining cash payment is to be made through

5In March 1991, Nigeria reached preliminary agreement with its bank creditors on a financing package incorporating debt and debt-service reduction through a cash buy-back and a collateralized bond exchange. Finalization of this agreement had been delayed by differences over the form of principal collateral for the bond exchange. These differences were resolved in late September. The agreement includes three financing options affecting $\$ 5.8$ billion of eligible debt: (1) a buy-back at a price to be announced by the authorities (subsequently set at 40 cents); (2) an exchange of debt for registered bonds carrying a fixed interest rate of $5^{1 / 2}$ percent for the first three years and $6^{1 / 4}$ percent thereafter, repayable in one installment in November 2020, with fully collateralized principal and a 12-month interest guarantee; and (3) a new money option involving the exchange of existing debt for bonds carrying an interest rate of LIBOR plus $13 / 16$ percent and a 20-year maturity (including 10-years grace).

${ }^{6}$ On August 30,1991 , the Philippines reached a preliminary agreement with its bank creditors on a financing package incorporating new money facilities and two reduced interest par bond conversions. The "temporary interest reduction bonds" would carry a 15-year maturity (including a 7-year grace period) and interest rates rising from 4 percent in the first year to 6 percent in the sixth year, and LIBOR plus $13 / 16$ percent thereafter. One year's interest would be collateralized during the first five years of the bonds. The second bond exchange involves 25 -year instruments with a bullet maturity and carrying interest rates that increase from 5 percent in the first year to 6.5 percent in the sixth year, and remain at that level until maturity. Principal would be fully collateralized along with a rolling one-year interest collateral. 


\section{Chart 3. Terms on International Bank} Lending Commitments, 1973-1990

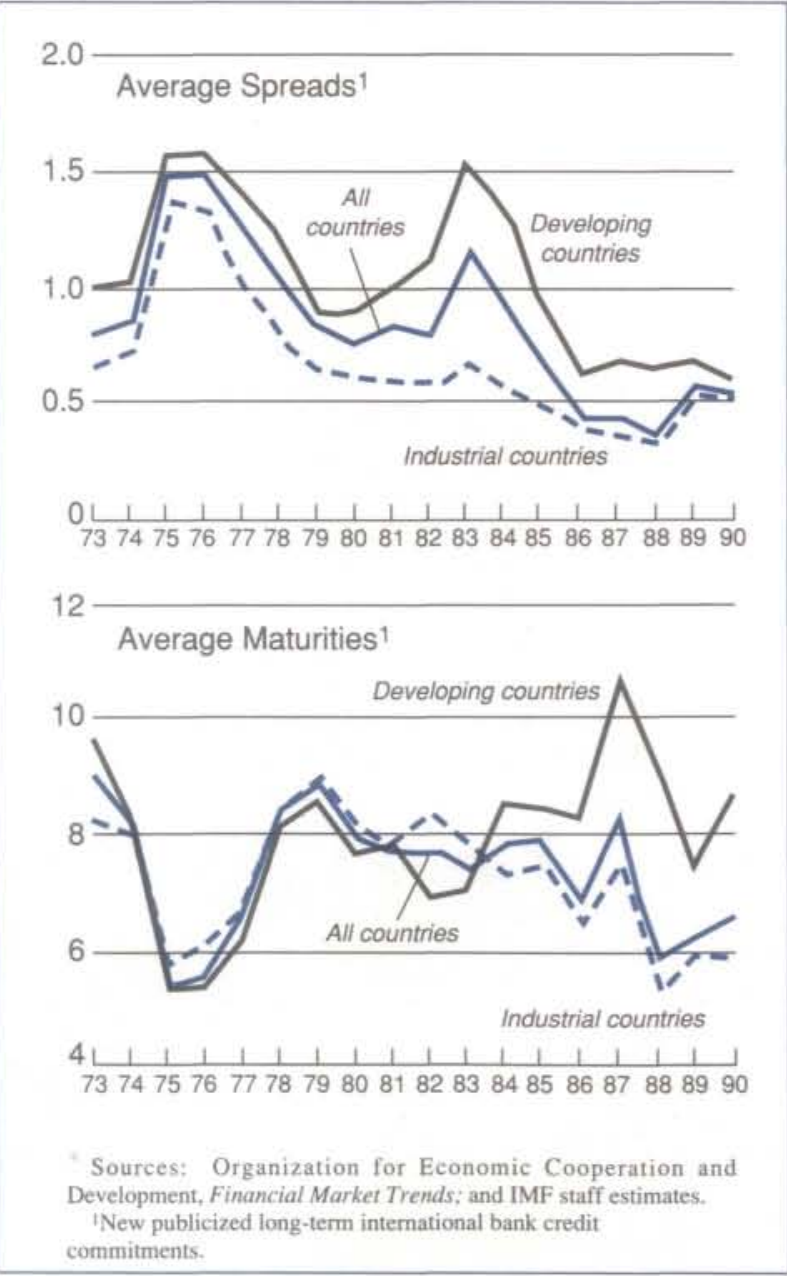

monthly installments, which began in July 1991, or in full at the time of agreement on the term sheet for the restructuring of medium-term debt. Agreement on this second term sheet will also allow for the conversion of the remaining portion of the interest arrears into 10-year bonds (with 3 years grace).

(2) There are some indications of a lessening of banks' reluctance to agree to high-discount debt reduction operations for low-income countries. While such countries account for a small portion of bank portfolios, banks had earlier appeared to be concerned that such agreements would create precedents for other countries. The Niger debt reduction package, completed earlier this year, is expected to be followed by one for Mozambique centered on a buy-back of the bulk of eligible debt. As in the case of Niger, debt reduction operations are to be financed partially through the Debt Reduction Facil- ity of the World Bank's International Development Association (IDA) and grants from bilateral donors.

(3) The ability of some countries to negotiate comprehensive "one-shot" restructuring packages continues to be hindered by high and mounting interest arrears, low international reserves, and limited access to funding for debt- and debt-service reduction operations. In some of these cases, the situation has been complicated by records of weak policy implementation. Against this background, a number of countries have attempted to adopt a phased approach, with the initial focus on banks' implicit or explicit acquiescence to interest arrears. This has been combined, in some cases, with partial cash payments and a degree of debt reduction through debt conversion schemes. Country experiences in this area have varied; they include the negotiation by Bulgaria of quarterly payments deferral agreements, a "goodwill payment" (of $\$ 95$ million) by Poland on accumulated interest arrears, and debt-equity operations by Argentina in the context of a privatization program, accompanied by partial interest payments.

Recent adaptations in procedures of the InterAmerican Development Bank (IDB) have expanded the sources of multilateral financing available to support bank debt- and debt-service reduction operations. New guidelines specify that, over a three-year period ending December 31, 1993: (1) up to 25 percent of the IDB's fast-disbursing sector lending program to a member country may be set aside to finance debt reduction, or, when the IDB is concentrating its support on project lending, about 10 percent of the bank's overall lending program to that country may be set aside to finance debt reduction; and (2) funds of up to 15 percent of the IDB's overall lending program to a country may be used to provide interest support. In order to qualify for financing under this facility, a borrower must have an adequate medium-term economic policy framework or structural adjustment program. It must also have a viable medium-term external financing plan, including debt and debt-service reduction, that represents an efficient use of IDB resources and offers reasonable prospects that the reduction will enhance the country's growth and development outlook.

\section{Debt Conversion Programs}

The estimated face value of commercial bank debt converted under the main official conversion schemes (excluding the discount and par bond exchanges undertaken in the context of comprehensive bank packages) rose from $\$ 7.2$ billion in 1989 to $\$ 10.5$ billion in 1990 (Table 7). The increase reflected $\$ 7$ billion retired by Argentina, in connection with 


\section{Bank Financial Packages, 1984-August 1991}

1984

Brazil: January ${ }^{2}$

Chile: January, June, and November

Sierra Leone: January

Guyana: January, July (deferment)

Nicaragua: February (deferment)

Peru: February ${ }^{3}$

Senegal: February

Niger: March

Mexico: April (new financing only)

Sudan: April (modification of 1981 agreement)

Yugoslavia: May

Jamaica: June

Zaïre: June (deferment)

Poland: July ${ }^{2}$

Madagascar: October

Liberia: December ${ }^{3}$

Zambia: December ${ }^{3}$

\section{5}

Côte d'Ivoire: March $^{2}$

Mexico: March, August

Costa Rica: May $^{2}$

Senegal: May

Philippines: May $^{2}$

Zaïre: May (deferment)

Guyana: July (deferment)

Argentina: August ${ }^{2}$

Jamaica: September

Panama: October ${ }^{2}$

Sudan: October (modification of 1981 agreement)

Chile: November ${ }^{2}$

Colombia: December ${ }^{4}$

Ecuador: December ${ }^{2}$

Madagascar: December (modification of 1984 agreement)

Yugoslavia: December

\section{6}

Dominican Republic: February

Morocco: February

Venezuela: February

South Africa: March (standstill)

Niger: April

Zaïre: May (deferment)

Brazil: July

Uruguay: July

Poland: September ${ }^{2}$

Romania: September

Congo: October ${ }^{2,3}$

Côte d'Ivoire: December

1987

South Africa: March

Mexico: March (public sector debt) ${ }^{2}$,

August (private sector debt)

Jamaica: May

Agreement classified by month of signature ${ }^{1}$

Mozambique: $\mathrm{May}^{3}$

Zaïre: May (deferment)

Chile: June

Honduras: June ${ }^{3}$

Madagascar: June (modification of 1985 agreement)

Argentina: August ${ }^{2}$

Morocco: September

Romania: September (modification of 1986 agreement)

Bolivia: November (amendment to 1981 agreement)

Ecuador: November (modification of 1985 agreement) $)^{2,3}$

Nigeria: November 2,3

Venezuela: November

Gabon: December ${ }^{5}$

Philippines: December

1988

Gambia, The: February

Chile: August (amendment to 1987 agreement) ${ }^{3}$

Uruguay: March (modification of 1986 agreement)

Côte d'Ivoire: Aprill ${ }^{2,3}$

Guinea: April

Togo: May

Poland: July

Yugoslavia: September ${ }^{2}$

Malawi: October

Brazil: November ${ }^{2}$

1989

Nigeria: April

Zaïre: June (deferment)

Poland: June (deferment) ${ }^{3}$

Honduras: August ${ }^{3}$

Jordan: September ${ }^{2,3}$

Niger: October ${ }^{3}$

Poland: July (deferment) ${ }^{3}$

Trinidad and Tobago: December

\section{0}

Philippines: February

Mexico: February ${ }^{2}$

Madagascar: April

Bulgaria: April (standstill) ${ }^{3}$

Costa Rica: May

Jamaica: June

Morocco: September

Senegal: September

Colombia: December ${ }^{4}$

Chile: December (amendments to previous agreements)

Venezuela: December

1991

Niger: January

Uruguay: January

Nigeria: March $^{3}$

Brazil: May ${ }^{6}$

Philippines: August ${ }^{3}$

Under negotiation

\begin{tabular}{|c|c|c|c|c|c|c|}
\hline Argentina & Brazil & Cameroon & Dominican Republic & Gabon & Honduras & Mozambique \\
\hline Bolivia & Bulgaria & Côte d'Ivoire & Ecuador & Guyana & Jordan & Poland \\
\hline
\end{tabular}

Sources: Restructuring agreements.

Note: "Restructuring" covers rescheduling and also certain refinancing operations.

1 Agreement either signed or reached in principle (if signature has not yet taken place); not all signed agreements have become effective.

2The restructuring agreement includes new financing.

${ }^{3}$ Agreed in principle or tentative agreement with banks' Steering Committees.

${ }^{4}$ Refinancing agreement.

${ }^{5} \mathrm{~A}$ separate club deal for new financing was arranged at the same time.

${ }^{6}$ Preliminary agreement on interest arrears. 
Table 7. Debt Conversions, 1986-First Quarter $1991^{1}$

(In millions of U.S. dollars)

\begin{tabular}{|c|c|c|c|c|c|c|}
\hline & \multirow[b]{2}{*}{1986} & \multirow[b]{2}{*}{1987} & \multirow[b]{2}{*}{1988} & \multirow[b]{2}{*}{1989} & \multicolumn{2}{|c|}{ First Quarter } \\
\hline & & & & & 1990 & 1991 \\
\hline Argentina & - & - & 764 & 1,180 & 7,038 & - \\
\hline Brazil & 176 & 336 & 2,095 & 942 & 483 & 52 \\
\hline Chile & 974 & 1,997 & 2,927 & 2,767 & 1,096 & 161 \\
\hline Costa Rica & 7 & 89 & 44 & 124 & 17 & $\ldots$ \\
\hline Ecuador & - & 127 & 261 & 31 & 42 & $\ldots$ \\
\hline Honduras & - & 9 & 14 & 47 & 32 & $\ldots$ \\
\hline Jamaica & - & 4 & 5 & 16 & 23 & - \\
\hline Mexico & 413 & 1,680 & $1,056^{2}$ & 532 & 435 & $\ldots$ \\
\hline Nigeria & - & - & 70 & 304 & 217 & 30 \\
\hline Philippines & 81 & 451 & 931 & 630 & 378 & $118^{3}$ \\
\hline Uruguay & - & - & 104 & 53 & - & - \\
\hline Venezuela & - & 45 & 49 & 544 & 716 & - \\
\hline Total & 1,651 & 4,738 & 8,320 & 7,170 & 10,477 & $\ldots$ \\
\hline \multicolumn{7}{|c|}{$\begin{array}{l}\text { Sources: Central Bank of Argentina; Central Bank of Brazil; Central Bank of Chile; Mexico, Ministry of Finance; Central Bank of Philippines; Bank } \\
\text { of Jamaica; Central Bank of Venezuela; and IMF staff estimates. } \\
\text { 'Face value of debt converted under official ongoing schemes. Figures do not include large-scale, one-off cash buy-backs and debt exchanges. } \\
\text { 2Does not include an estimated \$6-\$8 billion related to prepayment at a discount of private-sector debt since August } 1987 \text { signing of an agreement to } \\
\text { restructure foreign exchange risk coverage trust fund debt. } \\
{ }^{3} \text { As of April 30, 1991. }\end{array}$} \\
\hline
\end{tabular}

the privatization of Entel (the telephone company) and Aerolineas Argentinas (the national airline), which offset reduced activities in several other countries. As in previous years, Chile continued to account for an important share of the conversions, although at a declining rate consistent with a reduction in available bank claims and an increase in secondary market prices. Partial data for the first quarter of 1991 point to a slowdown in the rate of debt conversions, most noticeably in Argentina and Chile, but an increase was recorded for the Philippines as a result of more frequent auctions under its debtequity program. Finally, there are growing indications of a forthcoming increase in debt conversion activities, mainly as a result of privatization-linked debt-equity swaps, but also owing to various other debt conversion programs (for example, debt-fornature, debt-for-education, and so on).

\section{Developments in Selected Countries}

In April 1991, the Chilean authorities relaxed the repatriation regulations governing the sale of investments acquired through debt conversion programs covered by Chapter XIX of the country's foreign exchange regulations (Table A16). ${ }^{7}$ Specifically, the

\footnotetext{
${ }^{7}$ Official debt-equity conversions with remittance rights are covered by Chapter XIX, which allows investors to convert debt into domestic currency to finance equity purchases. Other conversions without remittance rights are carried out under Chapter
}

new rules allow investors to repatriate capital after three years-instead of the previous ten yearsthereby aligning the minimum holding period with that required for foreign direct investment. ${ }^{8}$ This change, which effectively increases the liquidity of investments obtained through the Chapter XIX debt conversion route, offsets to some extent the impact of a growing scarcity of Chilean debt paper and a narrowing of secondary market discounts.

Further auctions have been held under the debt conversion program of the Philippines. The secondquarter auction, held in April 1991, retired \$75 million in claims (face value), after $\$ 138$ million was tendered. Successful bids carried discounts ranging from 52 percent to 53.75 percent. In the previous auction, held in February 1991, the authorities reported tenders of $\$ 420$ million, with successful bids having discounts of 51.75 percent to 54.75 percent. A third auction was held in August 1991.

In Mexico, it appears that only a small portion of the "conversion rights" awarded in the two auctions held last year have been exercised to date. These auctions affected $\$ 3.5$ billion (original face value) of bank claims and resulted in $\$ 1.7$ billion of swap

XVIII, which allows exchanges on the basis of the repatriation of foreign assets of Chilean residents and foreign exchange acquired on the parallel market.

${ }^{8}$ Investors will be required, however, to pay compensation to the central bank on a sliding scale linked to the time the investment is held and the discount obtained through the debt conversion. 
rights being awarded at an average discount of 52 percent. Successful bidders were required to deposit claims equivalent to 5 percent of the rights acquired, with the remainder to be paid within 18 months. Other recent debt conversion activities include an April 1991 \$3 million "debt-forscholarship" swap signed with Harvard University, and a debt-for-nature program of up to $\$ 300$ million annually to be partially financed by the InterAmerican Development Bank.

In Venezuela, the authorities have approved aluminum projects of $\$ 1.2$ billion to be funded up to 30 percent through debt conversion operations. This follows the December 1990 approval of nine petrochemical projects involving a total investment of $\$ 2.6$ billion, of which $\$ 0.6$ billion may be funded through debt swaps. Major debt conversion programs currently in the pipeline include debt-forshare swaps in Brazilian companies being privatized and a new debt-for-equity scheme in Uruguay.

\section{Other Developments}

The recent period has also witnessed a growth in debt conversions initiated by international agencies and relief organizations, a development covered more fully in Chapter V in the context of low-income countries. Although still relatively small in magnitude, such conversions are becoming more widespread. Agencies typically obtain secondary market bank claims and convert them into local currency to finance a particular activity. In the case of UNICEF, for example, debt is obtained from banks and retired on the condition that the beneficiary debtor government contributes an agreed amount in local currency (involving a discount from the face value of the debt) to be used for a UNICEF development program for children. UNICEF acquires the debt through direct donations by banks or through purchases financed by grants from industrial countries.

A broadly similar mechanism is also being used by environmental agencies in the context of debt-fornature swaps. Earlier in the year, for example, the World Wildlife Fund and Conservation International obtained commitments for up to \$6 million of debt (face value) from a U.S. bank to fund conservation activities in Mexico and Ecuador. Similar operations have taken place in several other countries including Bolivia, Costa Rica, the Dominican Republic, Madagascar, Nigeria, Panama, the Philippines, Paraguay, Sudan, and Zambia. A comparable scheme, although involving the use of official bilateral debt, is being formulated in Poland. ${ }^{9}$ The impact of these operations varies according to program

\footnotetext{
${ }^{9}$ This would involve converting up to 10 percent of outstanding official bilateral debt to Paris Club creditors into local currency proceeds. The proceeds would be placed in a $\$ 3$ billion fund to finance environmental projects.
}

designs and implementation procedures. The net benefits depend on the cost-effectiveness of the debt conversions, total nature-related budgetary spending, and consistency with overall macroeconomic policies.

\section{Secondary Market for Bank Claims}

\section{Price Developments}

During the second half of 1990 and early 1991, secondary market prices for bank claims on developing countries were strongly influenced by a number of market shocks that affected the financial position of claim holders. These included Iraq's invasion of Kuwait in August 1990 and subsequent "distress sales" by some Middle Eastern banks of developing country claims; attempts by traders to reduce trading portfolios in anticipation of further sales by some banks as the Middle East crisis deepened; and rationalization by some Japanese banks of loan portfolios in light of tightening capital-asset constraints and falling equity prices in Japan.

In contrast, since early 1991 , the debt situation has not been marked by any major changes in the financial conditions of the main institutional participants in the secondary market. Accordingly, price developments have tended to reflect primarily changing circumstances in debtor countries. Most evident is the sharp narrowing in discounts on bank claims on countries that have regained access to voluntary capital market financing.

Discounts on claims on Chile, Mexico, and Venezuela have narrowed substantially during 1991, accounting for a significant improvement in average discounts for the group of 15 heavily indebted countries (Chart 4). The average price for bank claims on these 15 countries has increased by some 34 percent since the start of the year, with the end-September level being the highest since July 1987. Chilean claims are now trading at a price of about 90 cents on the dollar, in line with that observed for a number of developing countries that have avoided debtservicing problems. The average discount on Mexican claims ("stripped," so as to reflect the Mexican country risk element) ${ }^{10}$ has narrowed by about

\footnotetext{
${ }^{10}$ The reported market prices for bank claims on Mexico and Venezuela have been adjusted, or stripped, to exclude the collateralization of principal and interest on the discount and the reduced interest bonds acquired in exchange for the old debt. Movements in such stripped prices thus reflect changes in the underlying market perceptions of country risk. The increases in these measures of country risk are more pronounced than for the composite instruments, since the latter incorporate the relatively stable value of the principal and interest collaterals. With regard to absolute price levels, the stripped Mexican and Venezuelan prices have been rebased to ensure, among other things, continuity with price developments for the (totally uncollateralized) bank debt instruments that preceded U.S. Treasury Secretary Nicholas Brady's debt initiative.
} 
Chart 4. Secondary Market Prices for Developing Country Loans (In percent of face value))

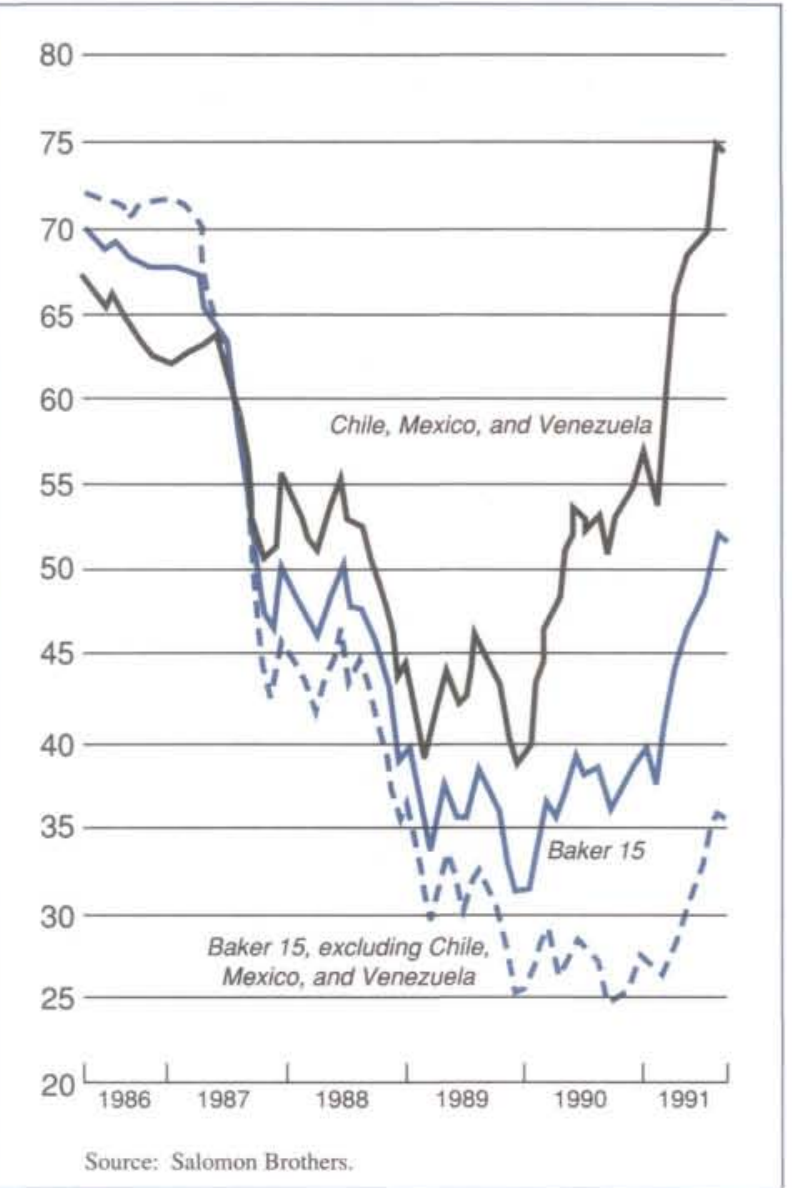

17 percentage points, with a particularly strong rise in the price for fixed interest par bonds as a result of the reduction in LIBOR rates. The discount on Ven- ezuelan instruments, also adjusted to reflect country risk, has recorded a similar movement. Specifically, the discount narrowed by some 20 percentage points through September 1991, with comparable changes in the relative prices of the bond instruments.

Other highly indebted countries experiencing substantial narrowing in discounts in the first three quarters of 1991-largely in response to market perceptions of improved economic and financial prospects-include Argentina (also aided by expectations of further privatization-linked debt-equity conversions), Brazil (reflecting as well the agreement on arrears), Colombia, the Dominican Republic, Morocco, Panama, Peru, and the Philippines.

\section{Institutional Market Developments}

The secondary market for bank claims has grown steadily in recent years. The nominal value of debt traded is estimated to have increased from less than $\$ 5$ billion in 1985 to $\$ 70$ billion in 1990 . Several market participants are projecting a further rise to about $\$ 200$ billion for 1991 as a whole. At the same time, market instruments have expanded, with the major impetus provided by recent bank financing packages that involved various collateralized bond conversion options. These developments have been accompanied by institutional changes, including the formation in December 1990 of an "LDC Traders Association," aimed at increasing market efficiency through standardizing documentation and trading practices.

In August 1991, a new "global index" of developing country debt instruments was launched by the F.P. Consult Company of France, as the prelude to standardized futures and options trading. Contracts for the standardized derivative products are to be cleared by a Swedish Exchange and Clearing House (OM Clearing) and are expected to provide greater depth to the underlying market. 


\section{Restoration of Access to Voluntary Capital Market Financing}

T his chapter reviews the recent experience of selected developing countries in borrowing on international capital markets, particularly through bond and equity placements. It focuses on the experience of a number of Latin American borrowers, especially Mexico, Venezuela, and Chile, which have shown signs of regaining access to voluntary financing on international capital markets. ${ }^{11}$ This contrasts sharply with the years following the onset of the debt crisis in 1982, when most financing took the form of principal rescheduling and concerted new money agreements.

For some re-entrants to the capital markets, yields have been declining both on primary and secondary markets-first on shorter-term instruments and then on longer-term obligations - and resources mobilized have been growing. Recent experiences of these and other borrowers demonstrate the sensitivity of yields and market access to changes in the external environment (such as the events in the Middle East in the second half of 1990) and to slippages in policy implementation. In contrast to the early years of the debt crisis, most new medium- and longterm financing raised by re-entrants has been mobilized through bond issues (initially of short maturity and occasionally enhanced through collateralization and other techniques), as well as equity placements. This shift in instruments has important implications for the division of risks among borrowers and creditors, as some techniques involve a stronger precommitment to repay regardless of outcomes unfavorable to the borrowing country, whereas others entail linkages between changes in the borrower's circumstances and returns to creditors.

\section{Recent Developments}

A number of formerly credit-constrained borrowers from Latin America have recently succeeded in placing voluntary debt issues on the international capital markets. The process of market re-entry has been accelerating, led by Mexico. Venezuela, which had an earlier but unsustained episode of revived access in 1988-89, has also been able to mobilize increasing flows over the last year and a half. For

\footnotetext{
"See also El-Erian (1991a) and IMF (1991).
}

both countries, secondary market yields on existing bonds have fallen sharply, especially since early 1991. This has facilitated efforts to extend maturities and obtain better terms for new issues (Table 8). Chile, which has also seen a sharp improvement in its credit standing, has experienced inflows mainly through direct and portfolio equity investment. In recent months, Argentine and Brazilian borrowers have also begun a limited re-entry, largely with short-dated obligations at relatively high yield spreads.

Mexico's success in attracting significant new inflows through international capital markets follows a sustained period of adjustment and structural reform, complemented by debt management policies designed to place the country's external indebtedness on a sustainable basis. ${ }^{12}$ The most notable feature of Mexico's market re-entry has been the raising of medium-term capital through the issuance of bonds on U.S. and European markets, largely by public-sector entities with established international reputations. Significant flows have also been mobilized through equity placements, issues of short-term certificates of deposit, and voluntary bank lending. Information compiled from various market reports indicates that Mexican entities launched some $\$ 5.2$ billion in bond issues between June 1989 and September 1991 (Table A17). After peaking at nearly $\$ 1$ billion in the third quarter of 1990 , the pace of issues slowed during the fourth quarter of the year, when new placements fell to $\$ 300$ million in the wake of unsettled conditions in international bond markets occasioned by the crisis in the Middle East. With the general improvement in bond market conditions in 1991, activity accelerated once again, with total issues of approximately $\$ 2 \frac{1}{2}$ billion in the first nine months of the year.

A range of financial techniques, including collateralization, has facilitated the return of Mexican borrowers to the international credit markets. In 1987, Teléfonos de Mexico (Telmex), the national telephone company privatized in 1990 , launched the first of several private placements backed by pledges of long-distance receivables. By mid-1991, Telmex had

\footnotetext{
${ }^{12}$ For a further discussion of Mexico's external debt management policies since 1982 , and the country's return to voluntary capital market financing, see El-Erian (1991b).
} 

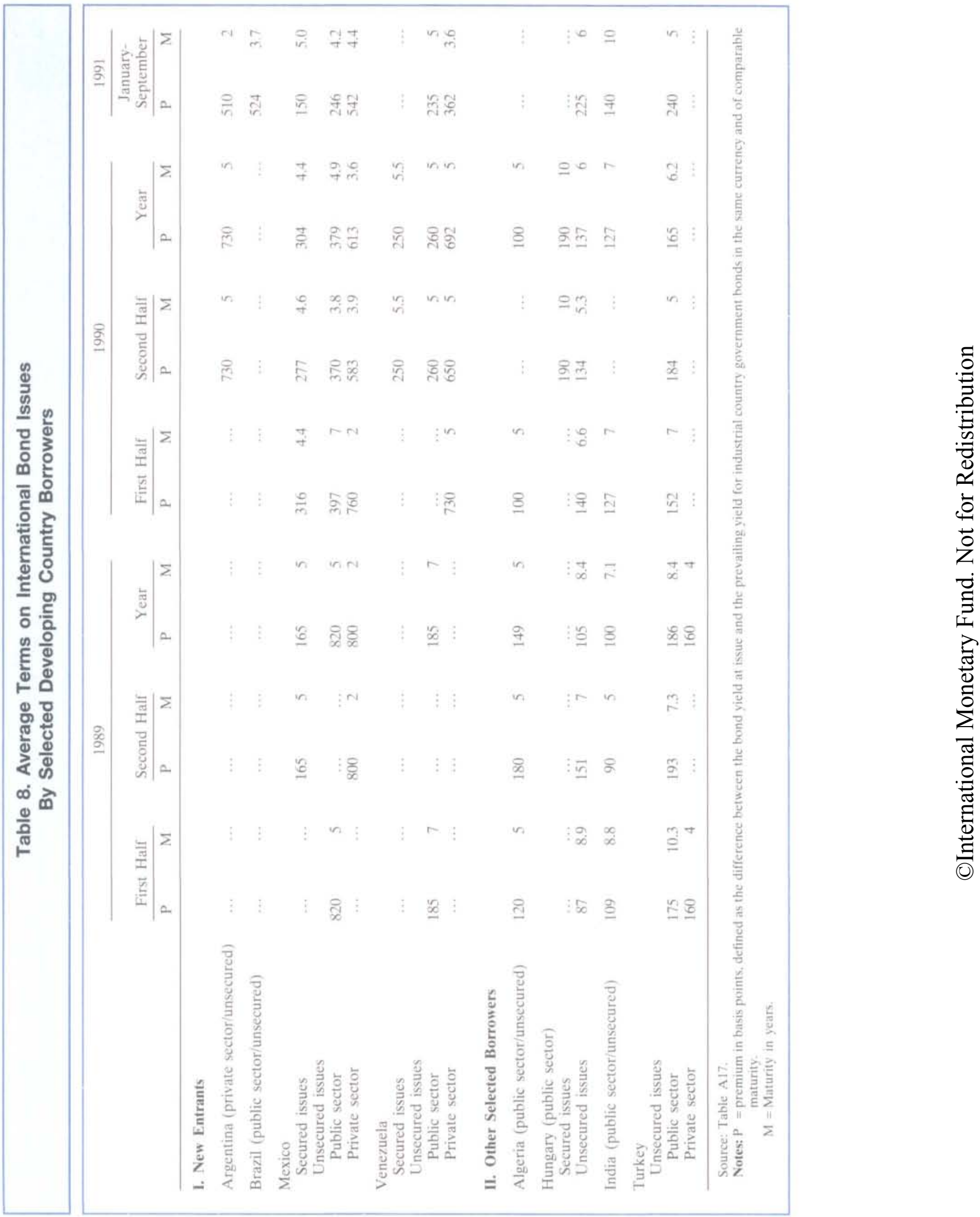
raised over $\$ 2$ billion through five such borrowings, as well as $\$ 150$ million through a two-year unsecured private placement issued under Rule 144a of the U.S. Securities and Exchange Commission (SEC). ${ }^{13}$ Over the last two years, collateral-backed offerings, such as those by Telmex-including two issues by Mexican banks backed by credit card receivables and one secured by receivables arising from electricity sales in the United States-accounted for an important portion of total Mexican bond placements. More recently, however, a growing number of unsecured bond issues have also been placed, and on progressively better terms. The range of participants has broadened during 1991, with the Mexican Government placing two issues in European markets. The first, a five-year DM300 million offering in February 1991, carried an initial yield of about 200 basis points over comparable German government securities. The second, denominated in pesetas and issued in Spain in July, had a five-year maturity and an initial yield of 175 basis points over yields on comparable Spanish government bonds.

In addition to medium- and long-term flows raised through bond issues, since early 1990 Mexican financial corporations have also succeeded in raising significant amounts of capital through the placement of short-term Euro-certificates of deposit (typically 90 to 180 days) through their London and, to a lesser extent, New York and Cayman Island branches. The proceeds have been on-lent to Mexican corporate borrowers, with the banks earning an intermediation spread. Such placements are thought to account for a significant proportion of the $\$ 4.3$ billion in private capital inflows received by Mexican banks during 1990; as of mid-1991, an estimated $\$ 5$ billion of Mexican Euro-CDs were outstanding. The issues, typically in bearer form, have reportedly been placed mainly with European investment houses, London branches of U.S. banks, private banking units of commercial banks, fixed-income funds, emerging market funds, and European and Latin American money managers. Mexican corporations have also had some success in raising short-term funds through overseas placements of commercial paper. Following the first issue by a private-sector steel company (Hylsa) in April 1991 at a yield of 12 percent, five other corporations had launched issues by September and others were reported to be preparing to enter the market. In August 1991, the Mexican authorities imposed reserve requirements against funds raised through Euro-CD offerings, leading market observers to expect a wider use of Eurocommercial paper by Mexican corporations in the future.

${ }^{13}$ Rule 144 a was introduced by the SEC in 1990 and governs secondary market trading in privately placed securities in the United States. For further details, see IMF (1991), Chapter V.
Improved perceptions of Mexican risk have been reflected not only in a relaxation in quantity rationing but also in a gradual decline in bond yields. In June 1989, the public placement by Bancomext-a public bank specializing in foreign trade-carried an initial yield of some 820 basis points above comparable U.S. Treasury bonds. This placement represented the first unsecured public-sector issue since 1982 and was launched in the midst of negotiations on a bank debt restructuring package. Since then, the weighted average yield spread on new unsecured issues has declined to approximately 550 basis points for private-sector issues and about 250 basis points for public-sector issues (Table 8). While even lower yields have been obtained on collateral-backed issues, these additional yield reductions appear to reflect more perceptions of the quality of the collateral than assessments of Mexican risk. Developments in initial yields on new issues have been accompanied by improvements in the yield spreads implied by reported movements in secondary market prices of publicly traded bonds (Chart 5). Yield spreads have narrowed dramatically in recent months, particularly on longer-dated instruments (including par and discount bonds), as the demand for Mexican risk appears to have outpaced a general increase in demand for higher-risk assets. As of August 1991, the stripped yield on Mexican par and discount bonds stood at about 530 basis points over the 30 -year U.S. Treasury bond rate, a yield spread about half that of socalled "junk" bonds. Yields on Mexican Euro-CDs have also declined substantially. In early 1990 , yields at the time of issue were on the order of $15-16$ percent; by July 1991 they had fallen to $8^{3 / 4}-9^{3 / 4}$ percent, depending on the issuer.

In 1988 and 1989, Venezuela was able to raise approximately $\$ 519$ million by placing several sovereign bond issues. In addition, in December 1988, bonds with a face value of $\$ 500$ million were exchanged for $\$ 400$ million in existing bank claims and $\$ 100$ million in new money commitments. Initial yield spreads on the new issues narrowed over this period, from approximately 350 basis points over the yield on comparable U.S. Treasury bonds to about 200 basis points. These yield spreads were considerably lower than those on commercial bank debt restructured under the 1984 multi-year rescheduling agreement, which ranged between 9.5 percent and 11.5 percent during the first nine months of 1988 . Secondary market yields on new bond issues subsequently widened sharply, reaching 19 percent in July 1989 . This reflected concerns about Venezuela's balance of payments, which also led to a near doubling of the yield on Venezuela's commercial bank debt between May 1988 and early March 1989 (Chart 6). As a result, Venezuelan borrowers ceased to be active in the market. Following the adoption of a comprehensive medium-term adjustment program 
Chart 5. Mexico: Yield Spreads on Selected Debt Instruments ${ }^{1}$ (In percent)

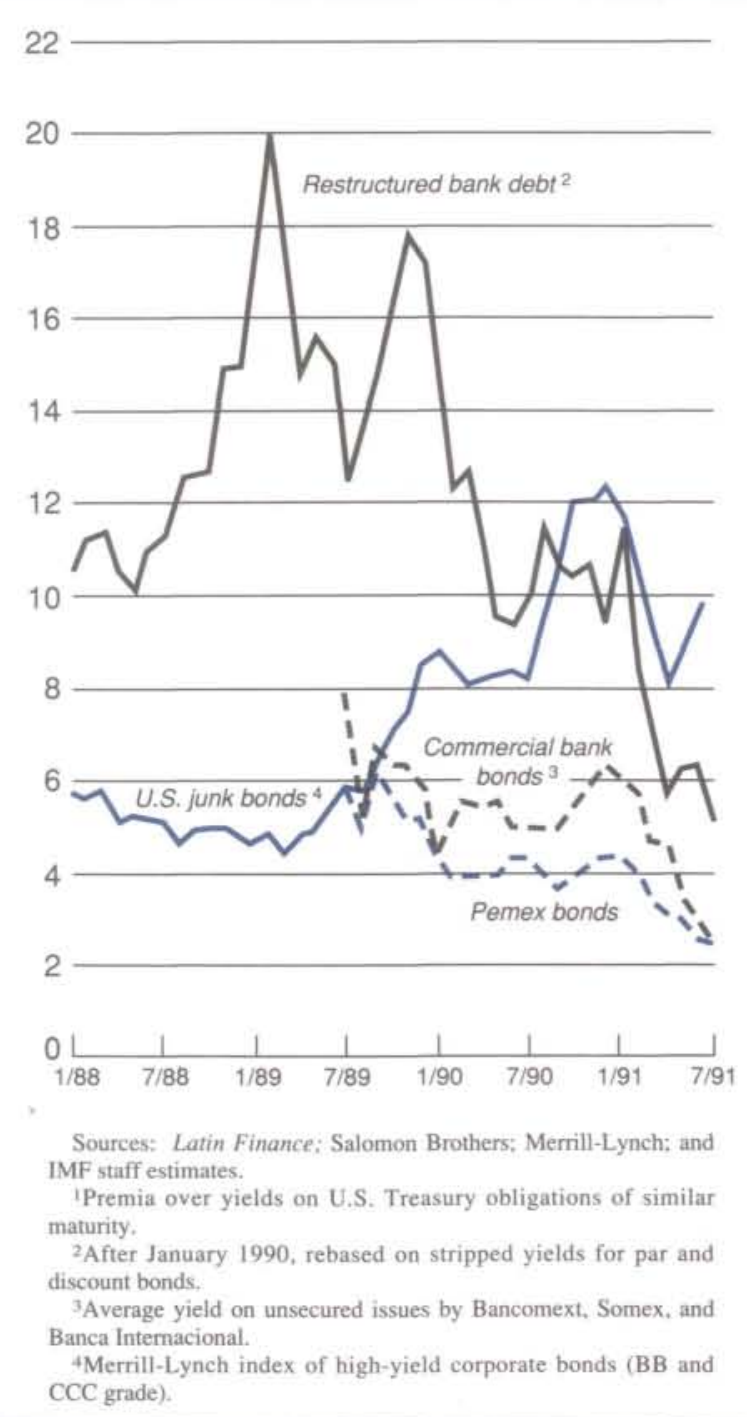

in mid-1989, however, and as prospects for finalizing a debt restructuring agreement with commercial bank creditors improved, yield spreads again narrowed considerably. Thus, in 1990, three private corporations and an offshore subsidiary of Petroleos de Venezuela (PDVSA), the state-owned oil company, were able to issue new securities. Unsecured issues by Sivensa, a private steel company, and Corimon, a private chemicals producer, carried initial yields of 16 percent and 15 percent, respectively; these subsequently traded down, for example, in the Sivensa case, to 14 percent seven months after issue. Reflecting enhancement through the collateralization of re-
Chart 6. Yields on Selected Venezuelan Debt Instruments

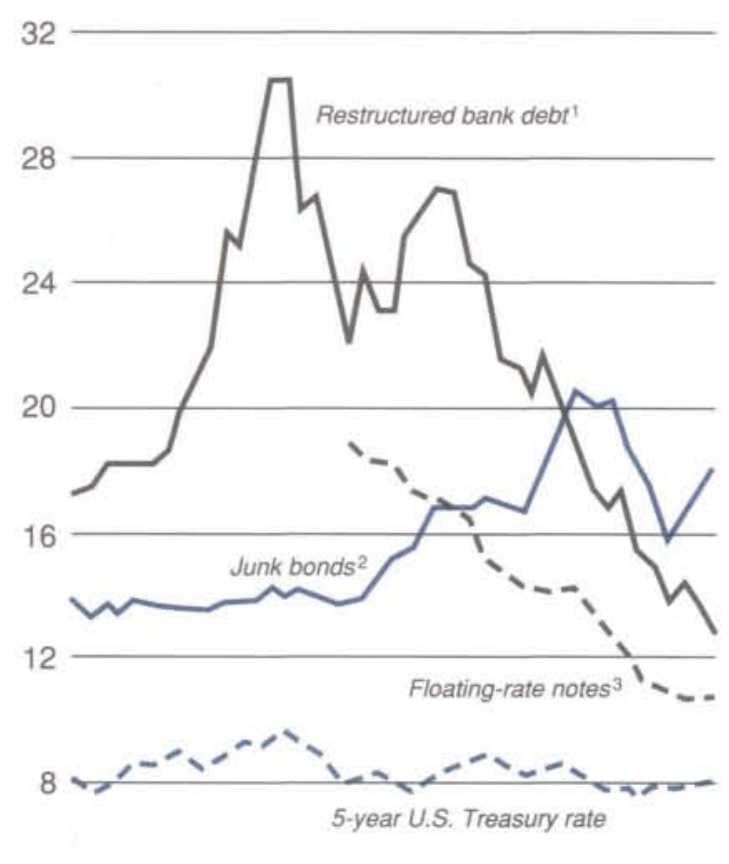

4

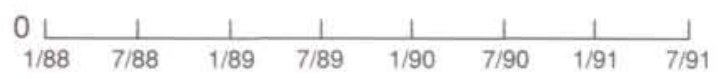

Sources: Latin Finance, International Financing Review; Salomon Brothers; and IMF staff estimates.

IAfter October 1990, rebased stripped yields on par and discount bonds.

${ }^{2}$ Merrill-Lynch index of high-yield corporate bonds (BB and CCC grade).

TWeighted average reported yield on floating-rate notes issued in 1988-89 and maturing in 1993, 1994, 1995, and (from September 1990) 1998.

ceivables from a long-term supply contract in the case of the other private sector issue (Sidetur), as well as the underlying strength of PDVSA, yields on these two issues were considerably lower. Yield spreads declined markedly further during 1991, and in August the Republic of Venezuela returned to the Euromarkets with a $\$ 150$ million five-year bond issue. The issue was increased from $\$ 100$ million in the face of higher-than-expected demand and, reflecting the recent upgrades in the rating of Venezuelan debt by Standard and Poor's and Moody's Investors Service (from $\mathrm{Ba} 3$ to $\mathrm{Ba} 1$ in the latter case), the new issue was placed with a yield spread of 235 basis points over U.S. Treasury issues. Also in August 1991, Vencemos, a private cement company, 
launched a two-tranche offering of two-year and five-year bonds totaling $\$ 75$ million, with an average yield spread of 360 basis points.

Chile has also recently experienced a significant improvement in its standing on international capital markets, with capital inflows largely taking the form of direct and portfolio equity investments rather than bond issues. In 1990 Chile secured a loan of \$20 million from NMB Bank (Netherlands), the first fully voluntary general purpose bank loan received by a Latin American sovereign borrower since 1982. In addition, in March 1991, the Republic of Chile issued \$200 million in bonds at 1.5 percent over LIBOR; a second tranche for $\$ 120$ million is scheduled for issue in March 1992. The bond issue was initially placed with creditor banks and was not tied pro-rata to their existing exposure.

Access by other Latin American countries has remained limited during recent years, although some activity is reported in cases of collateral-backed borrowings. For example, an Argentine oil and gas company (Bridas) is reported to have raised $\$ 80$ million through a three-tranche transaction involving collateralization. In a more widely publicized transaction, in December 1990, a private company, Molinos Rio de la Plata, placed a five-year $\$ 21$ million Eurobond issue (reportedly largely with Argentine investors) with an initial yield of 15 percent. In June 1991, Molinos returned to the market with an 18-month $\$ 15$ million issue priced to yield 10.7 percent. Finally, in September 1991, the Republic of Argentina raised $\$ 300$ million in a two-year bond issue (with a put option after one year), with an initial yield to maturity of 11 percent ( 510 basis points over comparable U.S. Treasuries), In July 1991, Petroleo Brasileiro (Petrobras), the state-owned oil company of Brazil, issued a $\$ 250$ million two-year note with a yield to maturity of 13.5 percent, equivalent to a spread of some 625 basis points. This was followed in August and September 1991 by four other issues by Brazilian entities (two by Telebras, including one denominated in ECU; one by Petrobras; and one by Companhia Vale do Rio Doce (CVRD), an iron ore producer).

\section{The Case of an Earlier Re-Entrant}

The experience of recent re-entrants may be compared with that of Turkey, which emerged in the second half of the 1980 s as a leading developing country borrower on the international capital markets. Turkey had lost access to private balance of payments financing in the latter part of the 1970s. Prolonged fiscal imbalances, together with an overvalued exchange rate, resulted in a balance of payments crisis and a need to seek recourse to debt restructuring with private creditors. Turkey's subsequent implementation of comprehensive adjustment measures, complemented by generous official financing, resulted in sustained growth and a significant structural transformation of the Turkish economy. In 1982, Turkey resumed syndicated borrowing internationally, some four years after its initial repayment difficulties. Initial flows were largely short term or project related, and from 1983 to 1987 Turkey's short-term indebtedness grew by some $\$ 5.1$ billion. The country was also able to attract capital through nonresident deposits, chiefly from Turkish workers in Germany.

Unlike the more recent re-entrants, Turkey's return to voluntary financing initially came through syndicated credits and only later through significant bond issues. During 1984-85, Turkey received approximately $\$ 760$ million in syndicated credits from commercial banks. Medium- and long-term inflows rose to $\$ 0.9$ billion in 1986 as Turkish banks placed about $\$ 145$ million in bond issues in Japan. Initial efforts to raise nonproject-related balance of payments financing were facilitated by cofinancing arrangements with the World Bank. In 1986-87, Turkey raised $\$ 580$ million from private sources through World Bank-sponsored B-loans. ${ }^{14}$ In 1987-88, publicsector bond issues increased sharply as Turkish borrowers placed an increasing number of issues in Germany. In late 1988, Turkey also began to tap the dollar market, both in the United States and offshore.

The terms on Turkish bond offerings improved steadily from 1987 through late 1989, as investors in the deutsche mark and then dollar markets became more familiar with Turkish risk. Following the onset of the Middle East crisis in the second half of 1990, however, yield spreads widened on Turkish bonds in the secondary market. In response to worsening market conditions, both public- and private-sector borrowers scaled back their activities in the second half of 1990 (when only one public-sector bond was placed) and in the first half of 1991. For the year 1990 , Turkish bond issues totaled some $\$ 0.6$ billion, compared with a peak of some $\$ 1.5$ billion in 1989 , although syndicated credits remained strong. By May 1991, secondary market yields had begun to decline, and the Turkish Government returned to the markets with a DM350 million fixed-rate issue carrying an initial yield of 10.9 percent, or 240 basis points over the five-year rate for comparable German issues.

\section{Instruments and Techniques}

The success of developing country borrowers in regaining access to international capital markets is

\footnotetext{
${ }^{14}$ Additional amounts were raised from private-sector creditors through cofinancing operations in which other creditors (for example, export credit guarantee agencies) guaranteed the exposure of the lending banks.
} 
related to their ability to address investor concerns about the risk of default (counterparty credit risk) and the risk that foreign exchange will not be available to meet debt-servicing obligations (country transfer risk). Credit terms are also affected by the extent to which lenders are confident that, if necessary, they will be able to trade debt instruments without unduly affecting the price before maturity (liquidity risk). In addition, developing country borrowers often face specific constraints imposed by informational deficiencies. While fundamental concerns about credit and transfer risks are clearly best resolved by efforts to improve the financial strength of the borrowing entity or country, the actual structuring of a transaction may play a complementary role. Various techniques used by market re-entrants to obtain funds are discussed below, and their efficacy is assessed in light of their contribution to addressing investor concerns. In addition, attention is given to the implications of the various techniques for future access and for sharing risk between lenders and borrowers.

\section{Bonds versus Syndicated Loans}

As discussed, the recent experience of Latin American borrowers in regaining access to the international capital markets has largely involved bonds rather than syndicated bank loans. This development is closely related to market perceptions of the seniority of bond instruments, which, in turn, reflect the continuing full servicing of these instruments by the major debtor countries even in the face of protraeted difficulties in meeting contractual obligations on other debts. Several other developing country borrowers have recently made more extensive use of bond markets. This contrasts with the experience during 1976-82 leading up to the international debt crisis, when publicized bond issues by developing countries totaled only $\$ 27$ billion, compared with $\$ 225$ billion in medium- and long-term publicized bank credit commitments.

A principal advantage of bond issues over syndicated loans is that they provide borrowers with access to a potentially broader range of investors. For borrowers that have maintained market access, this would appear to be a primary motive for bond issuance, since their bond yields have not differed greatly from yields on syndicated loans. In addition to raising funds from banks, which may still purchase an important portion of the bonds, bond issues enable developing countries to tap the interest of other financial institutions - such as insurance companies and investment funds-and of retail investors. Broadening the investor pool may have taken on added importance lately as tightening capital standards and provisioning requirements have re- duced incentives for banks to intermediate between lenders and riskier borrowers. ${ }^{15}$

Available information on the actual investor pool tapped by the bond issues of recent re-entrants is largely anecdotal. Some indications may be gleaned, however, from denomination sizes. Latin American Euro-CDs typically have denominations on the order of $\$ 100,000$ and registered bonds of around $\$ 250,000$, reflecting the fact that they are largely placed with institutional investors. Many of the recent bearer securities issued by Latin American borrowers, however, have had denominations in the range of $\$ 10,000$ to $\$ 50,000$ or even less, indicating the targeting of retail investors. The deutsche mark placements by Mexican borrowers in Germany have included denominations as small as DM1,000. Reportedly, a significant proportion of recent bond issues by Latin American borrowers, particularly initial offerings, were sold to investors from the region. For example, nearly half of the unsecured Sivensa issue is believed to have been purchased initially by Venezuelan investors. ${ }^{16}$ Nonetheless, the success of Mexican borrowers in achieving declining yields while raising increasing amounts of capital has occurred by tapping a progressively broader pool of investors. More recently, fund managers may have assumed a more important role in this effort. The broadening of the investor base in Mexican securities has also been facilitated by efforts to bring to market issues in a range of currencies.

One of the major constraints facing an entrant to the capital markets is a lack of familiarity with its prospects on the part of investors. If existing bonds are traded in the secondary market, subsequent movements in their yields - or in the yields of comparable issues - can be taken as a benchmark, thus facilitating future placements. For example, after being issued at an initial premium of 820 basis points in June 1989, the yield spread on Bancomext's 17 percent dollar bonds declined to around 400 basis points by mid-1990, at which time Bancomext was able to issue a deutsche mark-denominated bond at about 230 basis points over the German government bond rate. Thus, for some borrowers, including pri-

${ }^{15}$ In many cases (for example, Belgium, Japan, the Netherlands, and Switzerland), provisioning requirements are specifcally triggered by debt-servicing difficulties as reflected in payments arrears or debt reschedulings, and regulations typically specify that provisions must be maintained for at least five years after the most recent rescheduling agreement. In other cases (for example, the United Kingdom and the United States), a recent rescheduling or episode of arrears would be a factor underlying possible provisioning requirements. While specific provisioning levels vary from country to country, average bank provisioning levels against problem country exposure exceed 50 percent in most of the main banking center countries. Further information on national regulatory frameworks is contained in IMF (1990a), Chapter V.

${ }^{16}$ The factors affecting the attractiveness of such offshore securities to holders of flight capital are discussed in Chapter IV. 
vate borrowers, high yields paid on initial placements may be viewed as a kind of entry cost that paves the way to future issues on more advantageous terms when investors become more comfortable with the borrower's performance and prospects. ${ }^{17}$ In this regard, the significant participation of flight capital in new investment pools may be of value to other investors. Since residents may potentially be able to monitor developments in the borrowing country more closely than nonresidents, such reinvestment could constitute a particularly important signal for nonresident lenders considering further increases in their exposure in response to new developments.

Increased interest among international investors in bond issues by re-entering Latin American countries has led to, and been reinforced by, the establishment of credit ratings, which has reduced some of the costs investors face in compiling and purchasing information (Table 9). In December 1990, a ceiling rating for Mexican debt was issued for the first time and was set at $\mathrm{Ba} 2$ - just below investment grade. ${ }^{18}$ In July 1991, Venezuela's rating was upgraded from $\mathrm{Ba} 3$ to $\mathrm{Ba} 1$. Continued pursuit of policies aimed at stability and sustained growth can lead to the eventual attainment of investment grade status. Such status would, other things being equal, open to re-entrants new market segments, involving, for example, industrial country pension funds and other institutional investors subject to risk-level cutoffs. The opposite is, of course, also true. Some recent experiences demonstrate how rapidly the emergence of concerns about a country's prospects may be translated into a downgrading of a country's ratings and a concomitant increase in financing costs. ${ }^{19}$

${ }^{17}$ The success of such a strategy depends on the continued implementation-both at the entity-specific and countrywide level-of policies that raise perceptions of creditworthiness. Paying higher premia is not without its risks. Investors' willingness to acquire new debt claims may in fact decline in response to highpremium offers, partly because such offers may reasonably be interpreted as a sign of financial weakness that could undermine the soundness of the borrower. Such considerations would argue in favor of delaying efforts at re-entry until the establishment of policy credibility makes feasible the attainment of initial yields below some acceptable threshold. See Stiglitz and Weiss (1981) for a theoretical discussion of some of these issues.

${ }^{18}$ For certain countries (for example, Mexico), Moody's Investors Service issues ratings in accordance with a "sovereign ceiling rule," whereby no bond issuer can be rated above the sovereign rating given to the country in which it operates. Moody's believes that, although a nonsovereign entity may be better able to honor its obligations than its government over a given period, it is in general not possible to insulate a borrower consistently and over a long period from the sovereign risk of its home country.

${ }^{19}$ Examples of such shifts can be found in Hungary and India. Against the backdrop of a generalized flight to quality associated with developments in the Middle East and the assignment of a below investment grade rating by Moody's in mid-1990, secondary market yield spreads on Hungarian bonds increased sharply in the second half of 1990 and early part of 1991, peaking at around 300 basis points, compared with an average of about 70 basis points in the first quarter of 1990 . In recent months, sentiment
The attractiveness of international bond issues as a vehicle for developing country borrowers has been further enhanced by recent regulatory changes designed to reduce transaction costs and improve liquidity. The most important changes have occurred in U.S. markets, with the 1990 promulgation of "Regulation S" and "Rule 144a" by the Securities and Exchange Commission. ${ }^{20}$ In addition, regulators in Spain and Japan have taken measures to improve the access of developing countries to domestic bond markets. A decision by the Spanish authorities to permit Mexico to issue bonds on the "Matador" market led to the first issue of non-investment grade paper in that market. In June 1991, the Japanese authorities lowered the minimum bond rating required for an issuer to make a placement on the "Samurai" market-from A to triple-B in the case of sovereign (or sovereign-guaranteed) borrowers. This broader range opens the possibility of issues by some market re-entrants, as well as by borrowers that have retained access but have recently seen their ratings decline to below investment grade.

In addition to allowing borrowers to target a broader range of lenders, bond issues may also be advantageous in that they may be perceived as having seniority over existing obligations. Hence, despite concerns about a debtor's capacity to service all of its obligations, creditors may perceive that particular obligations are likely to be honored. Wellestablished, fully enforceable seniority arrangements do not exist for international contracts involving sovereign risk. Thus, prioritizing debt service on certain types of claims, either at the initiative of debtors or by voluntary agreement among creditors, is essentially an informal exercise not likely to provide full credibility among market participants. ${ }^{21}$ However,

toward Hungary has improved and yield spreads have declined to approximately 170 basis points as of June 1991. During the latter part of the 1980s, India expanded its presence in the Eurobond markets. Reflecting the country's investment quality $\mathrm{A} 2$ rating, Indian borrowers in the Euromarkets enjoyed some of the lowest spreads offered to developing country borrowers. But concerns about macroeconomic imbalances and events in the Middle East led to a series of downgrades by rating agencies starting in October 1990. Most recently, in May and June 1991, Indian long-term bonds were downgraded to BB+by Standard and Poor's and Ba2 by Moody's, below investment grade. Secondary market yield spreads on bond issues by state-owned enterprises rose significantly.

${ }^{20}$ Regulation $\mathrm{S}$ facilitates the marketing of Euro-securities in the United States by clarifying registration requirements; Rule 144a relaxes the waiting period requirement for secondary market trading in privately placed securities. For further information, see IMF (1991), Chapter V.

${ }^{21}$ It has been argued that the lack of seniority serves to destabilize sovereign loan markets. Unlike domestic bond covenants, where a clear hierarchy of debt claims can be established (leading to a steadily rising cost of funds), in the field of sovereign lending later creditors and earlier creditors are generally treated equally. Thus, lenders need to project not just the country's capacity to service existing debts, but also any new debts that might be incurred. This might, of course, encourage them to lend on a shorter-term basis. See Kletzner (1984) for a discussion of some of these issues. 
Table 9. Credit Ratings of Selected Developing Country Borrowers'1

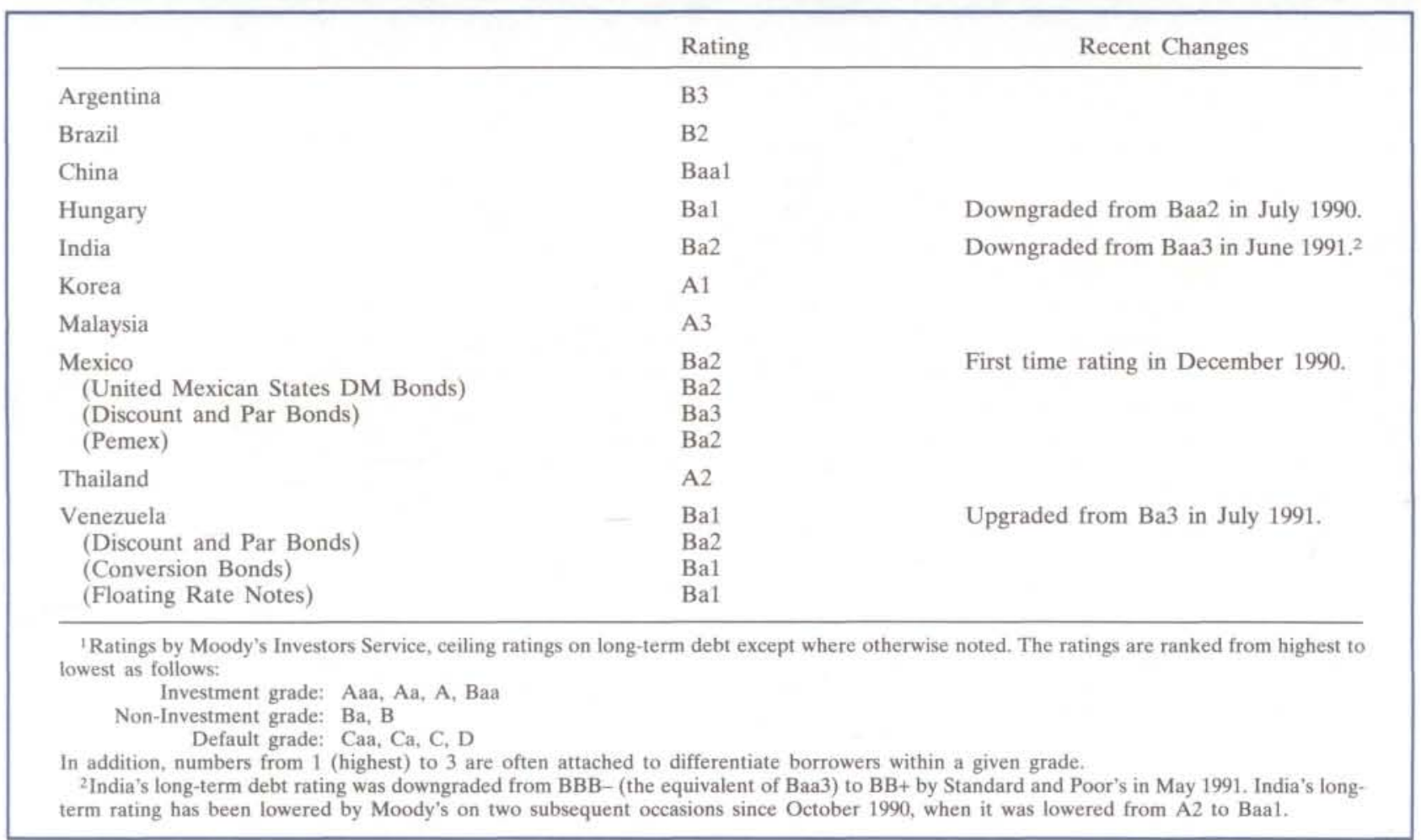

despite constraints on giving seniority to new flows over old in a credible manner through differential payments policies, secondary market prices for various types of developing country debt have generally reflected perceptions of payment priorities, especially in the case of major debtors. In particular, for countries that have encountered recent debt-servicing difficulties, sovereign bonds have traded in the secondary market at significantly lower yields than those implied by quoted prices on commercial bank debt, a reflection of their small share of total indebtedness and superior servicing record (Table 10).

Some observers have noted that the large-scale securitization of some developing countries' bank debts under comprehensive debt- and debt-service reduction packages could undermine the perceived superior quality of bonds over old bank debt and, as a result, slow the process of re-entry to international bond markets. This possibility may, however, not be significant if the restructuring of old bank claims is perceived to align more closely a country's overall indebtedness with its capacity to pay. In fact, restructuring agreements involving debt and debt-service reduction by Mexico and Venezuela have been cited by rating agencies as an important influence in assigning more favorable ratings to these borrowers than those given to some other Latin American debtors. Moreover, in the cases of Mexico and Venezuela, most of the bonds issued as part of the debtand debt-service reduction package were registered instruments. The rating agencies have cited this, as well as their link to previous syndicated credits, as considerations that make it more likely that holders of these bonds may bear a more than proportionate share of any resulting financial burden in the event of future debt-servicing difficulties. In both cases, therefore, bonds issued under the restructuring agreements have received lower credit ratings than the countries' overall ratings. Nonetheless, so long as a significant yield spread exists on a country's restructured debt, creditors may be cautious about extending financing that does not appear to have effective seniority over the bulk of existing claims. This would make it difficult to raise capital through syndicated loans, registered bonds, or bonds of long maturity.

\section{Use of Enhancements}

The recent success of developing country borrowers in re-entering international capital markets on favorable terms has in some cases been helped by 


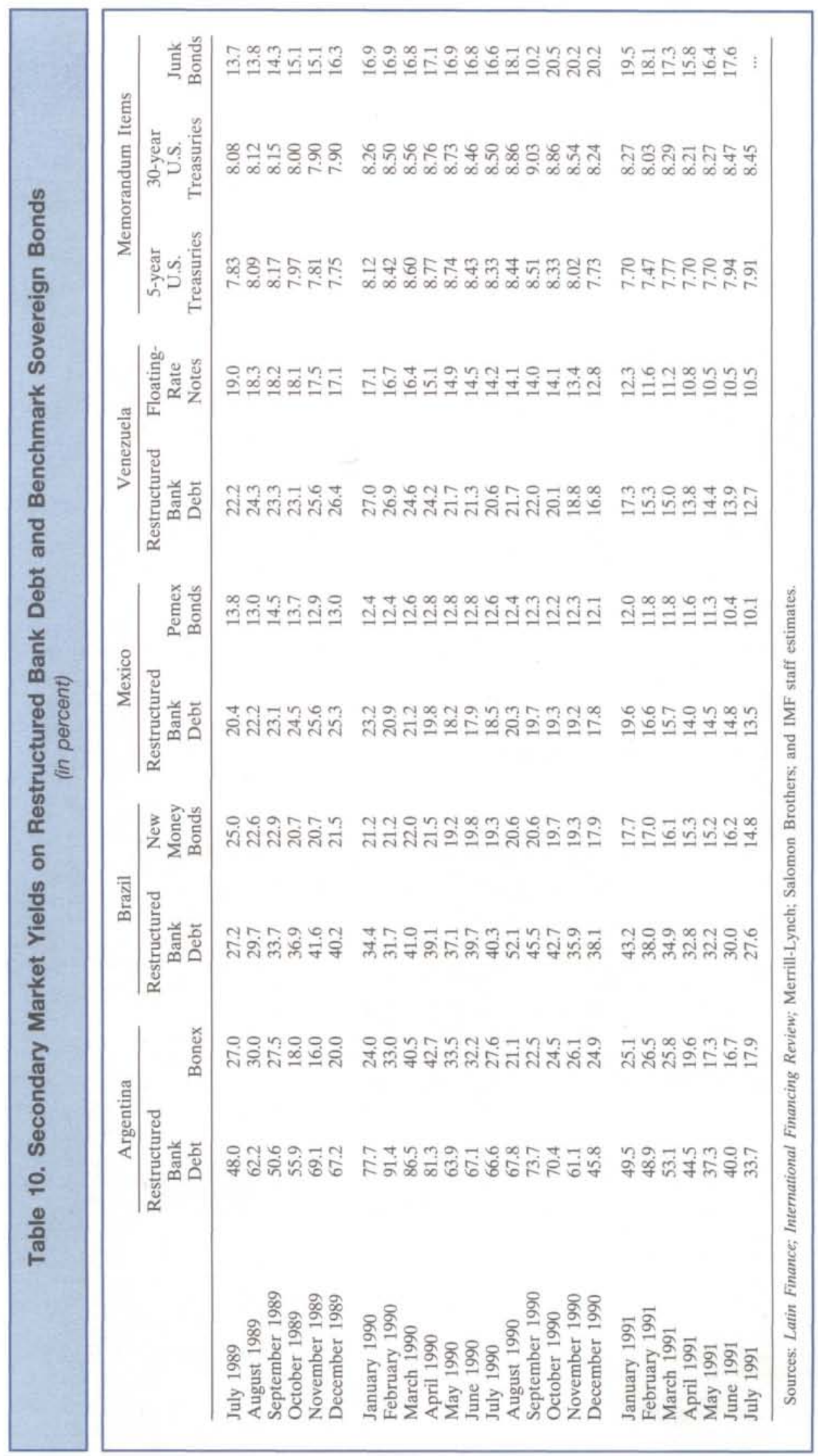


efforts to tailor instruments by using collateralization and other enhancement techniques. Such techniques can have important implications for the distribution of risk between developing country borrowers and their creditors. While some techniques, such as collateralization, shift risk from the creditor onto the borrower (and possibly the borrower's other creditors) by making the commitment to pay under all circumstances more credible, others allow the borrower to pay less under certain outcomes in return for a commitment to pay more when payments capacity improves. Several enhancement techniques used in recent borrowings are discussed below, including collateralization, the attachment of early redemption and equity conversion rights, and commodity price hedges.

\section{Collateralization}

One of the more widespread techniques used by borrowers to address typical investor concerns, and thereby to reduce financing costs, has been collateralization. For example, the Telmex-receivablesbacked issue in 1990 carried a spread of some 2 percentage points over LIBOR, compared with the July 1990 unsecured issue by the same company, which carried an initial yield of more than 450 basis points over U.S. government paper. Overall, the average initial yield on these secured borrowings is estimated at about 300 basis points lower than yields on unsecured private-sector issues for Mexican borrowers during 1990, and approximately 400 basis points lower for Venezuelan borrowers.

Recent collateralized borrowings such as these have involved the creation of a trust or special purpose vehicle (SPV), to which a secure income stream (such as receipts from a long-term supply contract) is assigned by the borrower. Against these future receipts, the SPV is able to issue securities, with the proceeds transferred to the borrower. ${ }^{22}$ In the case of the Telmex issues, the assigned income stream took the form of long-distance receivables from American Telephone and Telegraph (AT\&T). Instead of paying Telmex, AT\&T was directed to pay into the SPV, which then serviced the bonds. Other types of transactions have involved variations on such long-term supply contracts, in some cases involving commitments regarding price as well as volume.

Collateralization has succeeded in lowering borrowing costs, and in some cases may have paved the way for future access by promoting familiarity with

\footnotetext{
${ }^{22}$ Other types of collateralization structures have included the pledging of assets, including real estate, gold, and shares in companies. To some extent, these can be viewed as functionally equivalent to sales and repurchases of already-owned assets; the collateral-backed loan may be attractive in cases where it saves on transaction costs as compared with an actual sale and repurchase.
}

new borrowers under conditions of reduced risk. Such borrowings nonetheless have the potential fundamentally to impair rather than improve a country's ability to borrow on an unsecured basis. To the extent that creditors are confident that pledged assets or receipts will be used to honor newly created obligations, they are also assured that pledged assets will not be available to service other debt obligations or to finance imports. Moreover, as lenders may have concerns about the value of collateral they may have to realize on their claims, incentives exist for lenders to seek to have the loan overcollateralized, with implications for future borrowing. Depending on the structure of a transaction, collateral-backed borrowings can thus also reduce a borrower's financial flexibility. In short, unless inflows mobilized through collateralized borrowings are used in a manner that contributes to a country's overall creditworthiness, they may actually worsen prospects for later secured or unsecured borrowings. Nevertheless, the appropriateness of collateralization techniques should not be viewed narrowly or strictly on a transaction-by-transaction basis. The use of other financing techniques-for example, hedging operations and equity placements - can contribute to the cross-border diversification of risks, offsetting to some extent the loss of flexibility arising from the use of collateral. Fundamentally, however, it is the appropriateness of a country's overall macroeconomic policies - in particular, the extent to which interest and exchange rates give appropriate signals to market participants, as well as the sustainability of the country's savings-investment balance-that will determine whether future inflows will be available on less expensive terms.

\section{Early Redemption and Conversion Options}

Many recent bond issues by market re-entrants have been enhanced by early redemption options, which allow either the creditor or borrower to seek early repayment, or by conversion rights, which provide for conversion into equity in the borrowing enterprise at a prespecified price. Put options provide the holder the discretion to resell (put) the bond to the borrower at specified times (or, in some cases, following the realization of specified contingencies) at a predetermined price. Turkey made extensive use of put options in borrowings during late 1988 and 1989, with most of its major mediumterm borrowings containing such a feature. In one of the more innovative transactions, the Central Bank of Turkey raised $\$ 200$ million through a seven-year exchangeable loan facility (ELF) under which creditors could request conversion to a 6-month note after 18,30 , or 54 months. The ELF was intended to replace the Bank's short-term commercial paper borrowings. Several recent bond offerings by Mexican banks have also contained put options. 
A bond or a loan with a put option may be viewed as a combination of two loans. The first loan, which covers the period from issuance to the date the put can be exercised, is unconditional; while the second loan, covering the period from the exercise date to the maturity of the bond, is only extended if at that time creditors expect to earn a higher return than implied by the exercise price. For example, if the put price is equal to the issue price, lenders may wish to exercise the put because, relative to conditions at the time of issuance, the perceived risk of default has worsened or because market interest rates have increased. Since the second loan offers lenders a oneway bet, a lower interest rate can be offered on the first loan, proportional to the lenders' expected return on the second loan. Thus, the borrower, by committing to pay higher than its marginal cost of funds in the event payments prospects improve (or interest rates decline) beyond the level implied by the exercise price, is able to reduce borrowing costs during the pre-exercise period.

The use of put options naturally involves costs, not least because borrowers may be obliged to pay a higher yield after the exercise date than what lenders might require on a new placement. This may be mitigated, however, by savings on transaction costs. Borrowers might also hedge against the possibility of put options being exercised as a result of generalized interest rate movements by purchasing a put on a risk-free bond. Because of the risk of exercise, which could require raising additional capital on terms more costly than those implied by put prices (or might even lead to quantity rationing), the presence of put options should be taken into account in evaluating the maturity profile of a country's external debt. To the extent that they are significant, maturing put options need to be accounted for in projecting a country's debt-service ratios, along with a measure of the required average yield needed to avoid early repayment.

Call options allow borrowers to repurchase their bonds at a predetermined price and are essentially the mirror image of put options. They have been included in a number of bond issues by Mexican private-sector borrowers and in the recent issues by Petrobras of Brazil and Vencemos of Venezuela. In the event that a borrower's marginal cost of funds declines, the exercise of a call option allows expensive debt to be redeemed. The presence of such options can be expected to raise required yields on debt instruments to which they are attached as creditors seek compensation for their effective exclusion from upside gain. Call options may be particularly attractive to borrowers who consider that their prospects are set to improve at a time when the market substantially discounts such a possibility. Call options combined with put options effectively allow borrowers and creditors to specify a range of terms for extending the life of particular loans.
The attachment of equity conversion rights offers another means by which corporate borrowers can effectively lower their interest costs. Conversion rights can also be an attractive means of placing an equity issue where the appropriateness of current market prices may be difficult for investors to judge. Rather than specify a market-clearing price at the outset, the borrower sets a price it considers attractive from its viewpoint, and creditors are then given an incentive to evaluate the firm. Conversion rights have been attached to borrowings by two Mexican corporations: Tamsa, which has had an $\mathrm{ADR}^{23}$ listing in the United States since 1964, and Cemex, the largest cement company in Mexico and the third largest in the world. In addition to Mexico, other developing countries have also shown an interest in placing convertible issues. During the first five months of 1991, Asian developing countries reportedly issued more than $\$ 500$ million in convertible securities, compared with $\$ 80$ million in new issues during the same period in 1990. In March 1991, Malaysia issued $\$ 190$ million in bonds that are convertible into shares of the state-owned telecommunications company; the issue reportedly marked the first placement of a sovereign bond exchangeable for equity in a state-owned enterprise.

\section{Hedging Techniques}

The emergence of debt-servicing difficulties in a number of countries in the early 1980 s reflected the implementation of inappropriate domestic policies, compounded by unfavorable movements in commodity prices and real interest rates and by a sharp contraction in access to private external financing. To regain access, developing country borrowers need first to convince lenders that their policy stance is adequate. But sustained adjustment efforts, even when complemented by debt- and debt-service reduction operations that bring debt-service obligations into line with payments capacity, may still not be sufficient to allay lenders' concerns about the impact of exogenous risks. Re-entrants may therefore still face high spreads and quantity rationing, particularly in the longer maturities. To counter this problem, a limited number of borrowings have recently incorporated market-based hedging techniques. ${ }^{24}$ Such

\footnotetext{
${ }^{23}$ ADRs (American Depository Receipts) are U.S. dollar denominated equity-based instruments issued in the United States. ADRs are backed by a trust containing stocks of non-U.S. companies and set up with a U.S. bank by an intermediary who buys stocks in foreign markets. Trade in ADRs may take place directly among investors through custodian banks in the United States, thereby avoiding possibly expensive or risky clearance and settlement in foreign markets.

${ }^{24}$ For a detailed discussion of market-related hedging instruments of potential use to indebted developing countries seeking to manage financial risks created by price variability, see Mathieson, and others (1989).
} 
techniques offer the possibility of reducing or eliminating the risk of nonpayment owing to factors beyond the control of the borrower, such as fluctuations in export prices or world interest rates. They may be welfare-improving not only because of their insurance value, but also because they may reduce the expected cost of funds and improve market access by reducing the possibility of default.

Two loans for Mexicana de Cobre, a copper exporter, demonstrate the potential uses of price hedges. Under terms of the borrowings-the first in 1989 for \$210 million and the second in March 1991 for \$165 million-Mexicana de Cobre was essentially able to borrow in dollars and repay with a predetermined volume of copper. To mitigate transfer risk, the loans rested on long-term purchase contracts from a leading European mineral trading company. Through commodity swaps, the arranger in such cases hedges any mismatches between the dollar value of the commodity exported and the payments due to creditors. Participating lenders can thus receive payments with a fixed interest rate that they can swap into floating-rate obligations if they wish. Another example is that of Sonatrech, the Algerian oil company, which in 1990 signed a sevenyear $\$ 100$ million loan contract that included similar mechanisms. Sonatrech secured a favorable interest spread of 1 percent over LIBOR by entering into a series of options transactions that committed it to increase its payments if the price of oil exceeded a threshold level. Other examples of built-in hedges are the value recovery instruments included in the recent debt exchanges of Costa Rica, Mexico, Venezuela, and Uruguay. The instruments issued by Mexico and Venezuela were linked to the price of oil. Costa Rica linked its instruments to its rate of growth, and Uruguay, to changes in the price of a basket of key export and import commodities. These commitments were included in debt reduction packages to offer creditors the possibility of higher payments should debt-servicing capacities improve. To date, however, it has not been possible to secure lenders' agreement on downward contingency clauses, which would lower debt-servicing obligations in the event of adverse developments.

To some extent, the shift toward bond financing offers the possibility of hedging against interest rate risk through the flotation of fixed-rate bonds. ${ }^{25}$ The importance of the recent high percentage of fixedrate bonds is, however, somewhat illusory, since the maturity of the issues has tended to be short, particularly when the put options (which are more likely to be exercised if interest rates rise) are taken into

\footnotetext{
${ }^{25}$ The recent restructurings of Mexico and Venezuela involved the conversion of a significant proportion of existing debts into fixed-rate obligations, thereby reducing the countries' exposure to interest rate changes.
}

account. As the bonds are rolled over, any new issues will take place at a spread over then-prevailing interest rates. Hence, borrowers will still have incentives to hedge against longer-term movements in interest rates.

Borrowers need not explicitly incorporate price hedges into debt contracts to insulate their debtservicing capacity from fluctuations induced by price swings. ${ }^{26}$ Alternatively, they can independently engage in hedging operations to ensure that, should commodity prices move against them, the return on their position in the futures or forward markets will compensate them for the reduced value of their output in spot markets. For example, the Central Bank of Chile has made use of interest rate options to hedge against shifts in its cost of funds. Similarly, in late 1990 and early 1991, the Mexican Government reportedly purchased oil price puts, sold futures contracts, and used short-dated oil swaps to hedge its oil price risk. Announcement of operations of this type can give investors confidence in government paper, and in the country's obligations in general, by signaling that the probability of transfer problems arising in the near term from exogenous developments is significantly reduced.

The attractiveness of market-based hedgeswhich may, however, be limited in some cases in terms of coverage and duration-should be especially high for credit-constrained borrowers such as market re-entrants that have limited capabilities for smoothing unfavorable terms-of-trade shocks through additional borrowing. The same concerns about performance and transfer risk that limit their access to conventional credit markets, however, can also prevent them from using certain types of hedging contracts. This may be somewhat mitigated when the hedge position is covered, for example, in the case of an oil company selling oil forward. In the case of Mexicana de Cobre, transfer risk concerns were partially addressed by the pledging of receivables through a long-term supply contract. An alternative is to use put options that guarantee a mini-

\footnotetext{
${ }^{26}$ Creditors to borrowers vulnerable to price movements can also use commodity price hedges to protect against adverse movements in the value of their loans. However, to the extent that the lender's exposure is part of a diversified portfolio, the insurance value of hedging may be small. Moreover, even if lenders were to hedge, difficulties would still arise in the event of an adverse price movement in that the borrower's contractual obligations might exceed its payments capacity. While the lender may have already covered its capital loss on the expected receipts from the loan contract, it still does not have an incentive to write down the loan consistent with the borrower's reduced debt-servicing capacity. Hence, complex negotiations between the borrower and lender may still be needed to arrive at an accommodation between the borrower's payment capacity and its legal obligations. From the point of view of transaction cost efficiency, it would appear preferable that borrowers rather than lenders seek price hedges, if they are not to be part of the loan agreement itself.
} 
mum price and involve only a one-time up-front outlay by the borrower.

\section{Equity Issues}

In addition to the increasing importance of bond issues as a source of funds for some developing countries, the role of equity flows has also expanded recently. Gross foreign portfolio equity flows into emerging stock markets are estimated to have averaged about \$1 billion a year during 1987 through 1990 , with most of the inflows concentrated in developing countries in Asia. Apart from these traditional recipients, portfolio flows have also picked up in recent years in certain Latin American countries (particularly Chile and Mexico) and in Eastern Europe (particularly Hungary). One of the most important vehicles for mobilizing such flows has been country funds. Indeed, in many developing countries such funds provide the only channel for foreigners to invest in local equities. Typically, these are closedend funds, initially capitalized at about $\$ 50-\$ 150$ million and specializing in private-sector companies. ${ }^{27}$ During late 1989 and early 1990 , the number of country funds grew especially rapidly. It is estimated that \$1.5-\$2 billion was raised in 1990 . Much of this amount, however, including nearly $\$ 1$ billion raised for investment in Eastern Europe, was not fully employed because of time lags in finding sufficiently attractive investment opportunities.

In Chile, country funds began operating in late 1989; since then, $\$ 1.2$ billion in investments has been authorized, of which about $\$ 0.5$ billion was invested as of the end of July $1991 .{ }^{28}$ In addition, in July 1990 the privately owned telephone company of Chile, Compania de Telefonos de Chile, raised \$98 million ( $\$ 90$ million net of commissions and other costs) by issuing ADRs on the New York Stock Exchange. The CTC issue was the first international equity offering by a Latin American borrower in over 25 years. Significant equity portfolio inflows have also been registered in Mexico, where the value of foreign equity holdings is reported to have risen from less than $\$ 1$ billion at the end of 1989 to approximately $\$ 4.5$ billion by the end of 1990 , and close to $\$ 14$ billion by August 1991-reflecting both new inflows and an appreciation in share prices. While the foreign share accounts for only one fifth of total market capitalization, the foreign share of actively traded stocks is much higher, on the order of

\footnotetext{
${ }^{27}$ In a closed-end fund, the fund's resources are limited to a pre-set maximum and may be invested in a specific range of assets. After being fully invested, the size of the fund is held fixed until it is liquidated after a given time period.

${ }^{28}$ This includes about $\$ 0.1$ billion mobilized through three country funds that brought capital into Chile under the auspices of Chapter XIX of the country's debt conversion program.
}

50-60 percent. In addition to owning stock through ADRs and country funds (accounting for some $\$ 0.5-\$ 0.6$ billion), foreign investors also hold a significant portion of Mexican equities directly, normally through the purchase of nonvoting (class B) shares. ${ }^{29}$ Foreign purchases of voting shares are permitted in cases where there are no nonvoting shares, but they must be held in trust in a fund administered by the state-owned financial holding company, $\mathrm{Na}$ cional Financiera. Since the beginning of 1990, such shares have risen by more than $\$ 1$ billion.

The telephone company, Telmex, has accounted for much of the increased portfolio flows to Mexico; as of May 1991, some two thirds of the total foreign investment in Mexican equities was reportedly accounted for by foreign holdings in Telmex. The firm was privatized in December 1990, when the Government sold a controlling stake of 20 percent for $\$ 1.76$ billion to a consortium headed by the Mexican conglomerate Grupo Carso and including France's Telecom and Southwestern Bell of the United States. In May 1991, the Government sold an additional 15 percent share for $\$ 2.18$ billion in an international ADR offering; half of the shares were sold in the United States, with the remainder sold in Mexico and internationally. Reflecting considerable international interest, in June 1991 Bankers Trust issued covered warrants on Telmex stock, reportedly the first such transaction on a Mexican stock. The instrument allows investors to take a position on a possible upswing in the value of Telmex shares and is reported to be targeted mainly at U.S. investors.

In 1990, the number of Mexican companies with ADRs in circulation increased from three (Telmex, Tamsa, and Cifra B) to eight, with new issues by Interceramica, Sanluis, Sidek, EPN, and Tolmex, a subsidiary of Cemex. In addition, seven other ADR issues were reported during 1991 for leading Mexican companies with established domestic listings, which raised a combined $\$ 2.9$ billion (including $\$ 2.2$ billion by Telmex). The Femsa and Vitro issues were marketed through private placements in the United States under Rule 144a. In a transaction coled by the World Bank's International Finance Corporation, Apasco, Mexico's second largest cement company, also raised funds offshore by placing $\$ 50$ million in convertible subordinated debentures. Finally, in July 1991, Grupo Gigante, Mexico's second largest supermarket chain, became the first Mexican company to make an initial public offering with an international tranche. The offering involved $\$ 100$ million of shares marketed to investors in Mexico and $\$ 50$ million in ADRs sold in the United States and Europe, mainly to institutional investors.

${ }^{29}$ Cemex raised $\$ 190$ million through domestic issues of class B shares in two tranches in May and July 1991. A large proportion of these shares was reportedly purchased by foreign investors. 


\section{Summary and Conclusions}

The recent experience of re-entrants to international capital markets highlights the sharp improvements in both the volume of flows and the terms received. They also illustrate how rapidly market sentiment can change. To a certain extent, volatility in this regard is to be expected, given that a lender's assessment of repayment prospects encompasses not only perceptions about a borrower's policies, but also expectations about the intentions of other current and prospective lenders. The ability to borrow requires the availability of willing creditors. "Bandwagon" effects are therefore common, that is, a borrower becomes more (or less) creditworthy because an increasing (decreasing) number of lenders consider it to be so. But a virtuous cycle in this regard ultimately hinges on market views of the adequacy of underlying policies: if lenders view current or prospective policies as inadequate, not only will they fear a borrower default, but also a retreat of other lenders, compounding changes in expected returns on potential new loans.

Techniques currently used to mobilize foreign capital differ from those that re-entering borrowers have used on earlier occasions in a number of ways. Mobilizing capital through portfolio flows has allowed re-entrants to broaden the base of potential investors. This development is perhaps more important to re-entrants than for borrowers that retained market access because of the higher provisioning requirements that banks face in lending to them. The reliance on bond financing provides lenders and borrowers with continuous indicators of market expectations - through secondary market pricesand paves the way to lower yields on subsequent borrowings as perceptions of creditworthiness improve. To some extent, countries have been able to gain additional access, or more favorable terms, by using techniques that give lenders confidence that they will not have to bear the burden of future debtservicing difficulties. In an ultimately successful debt management strategy, however, such techniques can probably play only a marginal role. Efforts to obtain inflows by privileging certain claims may actually impair unsecured access over the longer term. Similarly, excessive reliance on short-term credits in the face of mounting longer-run uncertainties can limit access to longer-term credit, and ultimately even lead to a rundown in short-term credit as existing lenders perceive threats to their seniority. As with short-term borrowing, a primary motivation for techniques such as collateralization is to economize on risk premia; if borrowers succeed in reducing the overall level of risk, the frequency of such secured borrowings may be expected to decline.

The move toward techniques that entail greater risk sharing between borrowers and lenders, such as equity related instruments, may be more enduring if access to capital market flows is maintained and deepened. As lenders develop confidence in the overall adequacy of policies in borrower countriesthat is, as they become less concerned about downside risks owing to policy slippages and more convinced that upside benefits may be realized-these sorts of financings should become more feasible. Also of interest in this regard has been the limited experience of some countries with market-based hedging operations, both within and outside the context of specific debt contracts. Under certain circumstances, such techniques can offer efficient alternatives to borrowing and saving for purposes of income smoothing and can encourage higher overall capital inflows. Despite limitations imposed by concerns over transfer risk, significant scope appears to exist for wider use of market-based hedging techniques. Moreover, a virtuous cycle may exist, in that the more borrowers engage in hedging operations-in conjunction with other policies to improve their creditworthiness-the more creditors will come to view these borrowers as less risky and, hence, as credible counterparties for more extensive and complex operations. 


\section{Repatriation of Flight Capital}

T he flight of resident capital from developing countries during the 1980 s reflected and contributed to their economic and financial problems. Conversely, the recent repatriation of flight capital in some of these countries, following the sustained implementation of comprehensive adjustment programs and appropriate debt restructuring, has reinforced the restoration of economic growth. This chapter discusses conceptual issues related to capital flight, policy conditions conducive to repatriation, and some techniques employed to this end in specific cases.

The main influence on most private capital movements is the expectation of returns in a comparative context. Specifically, in cases where repatriation has occurred, stabilization policies have altered expected relative returns (that is, interest rate differentials between domestic investments and investments in socalled "safe haven" countries adjusted for exchange rate expectations) and improved the comparative attractiveness of domestic assets. In some cases, such policies have been supplemented by specific measures directed at promoting capital reflows, such as tax amnesties, liberalization of domestic capital markets, issuance of offshore securities and foreigncurrency-denominated assets, and the establishment of debt conversion programs. When implemented in a stable economic and financial environment, these measures have facilitated the return of flight capital, particularly at the beginning of a reform process. Such techniques have had little success in promoting capital repatriation, however, in the absence of accompanying financial and structural reforms.

\section{Definition and Estimation Problems}

The analysis of capital flight has been complicated by definitional and measurement problems. The first issue arises over disagreement as to whether capital flight should be defined in terms of its motivation or its consequences, and whether there is any clear-cut way of distinguishing capital "flight" from "normal" capital outflows. ${ }^{30}$ The most broadly accepted crite-

\footnotetext{
${ }^{30}$ For background, see Deppler and Williamson (1987), Dooley (1988), Dornbusch (1991), and Kahn and Ul Haque (1985).
}

rion based on motivation identifies flight capital as the component of private capital outflows resulting from attempts to avoid "exceptional sacrifices" on rates of return at home. Factors affecting expected rates of return include risks of expropriation and debt repudiation, the introduction or strengthening of capital controls, taxation, financial repression, and perceptions of the likelihood of inflation and exchange rate depreciation. These factors typically emerge under conditions of macroeconomic imbalance and structural distortion. An alternative view, which defines capital flight on the basis of its consequences, focuses on the national disutility of capital outflows. Such a notion encompasses all components of private capital outflows, on the premise that capital in developing countries is a scarce commodity whose loss will constrain economic development. Because of its breadth, however, "normal" capital outflows are also captured in this definition, for example, trade credits and normal flows associated with portfolio diversification. The usefulness of this broader concept arises in empirical applications where data are limited and deviations from trend levels of flows may be interpreted as indications of capital flight or repatriation.

Data problems often complicate measurement of the scope of capital flight. Difficulties are encountered at both source and destination. The very nature of capital flight movements complicates measurement from the vantage point of the source country. ${ }^{31}$ In addition, limited record-keeping and accounting resources in some developing countries have adversely affected the quality of nonbank and nongovernment accounts. Measurements based on "haven" country data also have limitations-arising primarily from a paucity of detailed data on the foreign asset holdings of nonresidents. Moreover, capital may follow circuitous routes, often passing through offshore centers with tight secrecy requirements. The most comparable source of inter-country data comes from bank data, which, however, capture only a small part of the phenomenon. In particular,

\footnotetext{
${ }^{31}$ Vehicles for the outflow of private capital include the use of parallel markets for foreign exchange, financing involved in the smuggling of precious metals or objects, improperly invoicing exports or imports, and various forms of parallel lending between residents and nonresidents.
} 
bank data do not cover portfolio reallocation in favor of nonbank stores of value, such as real estate, equity, and other private- and public-sector securities. ${ }^{32}$ In view of such limitations, estimates of capital flight are usually derived from flows contained in national payments balances, which usually present aggregate statistics on private-sector flows.

Numerous empirical studies have attempted to analyze capital flight using the two definitions described above. ${ }^{33}$ Using the second definition, which does not attribute motivation to capital outflows, capital flight is estimated by measuring short-term private capital outflows or total private capital outflows, including errors and omissions. The adequacy of the choice depends on the country-specific set of transactions that are the most likely vehicle for capital flight; for example, in countries without capital controls, medium- and long-term outflows may be significant conduits for capital outflows. Conversely, empirical studies based on the first or "motivational" definition must generally make ad hoc adjustments to balance of payments data by ascribing "flight" motives to certain components of private capital outflows. An exception is the "derived approach," which, in an attempt to formulate a consistent methodology, assumes that capital fleeing from exceptional risk will not lead to repatriated investment income. The stock of flight capital is thus calculated by subtracting from the total stock of external claims those imputed from data on investment income receipts. This methodology represents a lower bound to capital flight estimates, while the broader definition would represent an upper bound. ${ }^{34}$ Notwithstanding their limitations, studies covering the broadest set of countries indicate flight capital ranging from $\$ 200$ billion to $\$ 300$ billion during $1974-85$ for capital-importing developing countries as a group. ${ }^{35}$ For the 13 most highly indebted countries,

${ }^{32}$ An exception to the unavailability of nonbank data is the U.S. Treasury Bulletin, which contains breakdowns of holdings of U.S. securities by country of origin.

${ }^{33}$ These include Chartered West LB Ltd. (1991), Cuddington (1986), Cumby and Levich (1987), Deppler and Williamson (1987), Dooley (1988), Dornbusch (1991), Kahn and Ul Haque (1985), Lessard and Williamson (1987), Morgan Guaranty (1986), Rojas-Suárez (1991), and World Bank (1985).

${ }^{34}$ The shortcomings of these estimation methods have been amply discussed in the literature on capital flight. In brief, the criticisms of the broader measurements relate to (1) the inadequate estimates of capital flight arising from misinvoicing in the trade account; (2) the attribution of all errors and omissions to capital flight; (3) the omission of nonrepatriated investment income and other foreign exchange receipts; and (4) the overall inadequacies of many developing countries' debt and capital account statistics, including adjustments for exchange rate valuation effects. Estimates obtained from the "derived measure" are also sensitive to the accuracy of investment income data and assumptions regarding interest rates used to capitalize investment income. Moreover, they neglect capital outflows for which repatriation/reporting of investment income does occur.

${ }^{35}$ See World Bank (1985) and Deppler and Williamson (1987). the derived approach estimates net capital flight at $\$ 184$ billion by the end of $1988 .{ }^{36}$

In view of these conceptual and measurement problems, relatively timely indicators of capital flight or repatriation have had to be based on shifts in several measures of resident private capital flows. A primary indicator is the sum of errors and omissions and private-sector portfolio flows in balance of payments data. Other indicators, which may reflect conditions conducive to or conduits for capital flight/ repatriation, include the following:

- the interest-rate differential between domestic and foreign assets adjusted for expectations of movements in the exchange rate, given that empirical analysis finds an association between overvalued exchange rates, high inflation, negative real rates of return on domestic assets, and capital flight; ${ }^{37}$

- movements in the level of resident holdings in foreign banks, since foreign-held bank deposits are especially liquid;

- changes in the level of foreign currency deposits held domestically, the interpretation of which depends on assumptions about asset holders' confidence in the safety and risk-adjusted returns on domestic assets;

- domestic stock market activity, since price indexes may reflect shifts into or out of equity instruments; and

- the secondary market price for foreign-held indebtedness, which may indicate a generalized rise or fall in confidence in domestic economic and financial policies.

In a number of developing countries, the implementation of unsound economic and financial policies in the late 1970s and early 1980s was compounded by adverse external shocks. Capital flight often resulted from consequent deteriorations in domestic rates of return-adjusted for expectations of exchange rate changes and other risk factorsrelative to the returns available abroad. Tax policies at times compounded capital flight to the extent that domestic tax rates were relatively high, withholding taxes were not imposed by haven countries, or bilateral tax treaties between source and haven countries did not exist. In addition, movements to markets

${ }^{36}$ The 13 countries are Argentina, Bolivia, Chile, Colombia, Ecuador, Gabon, Jamaica, Mexico, Nigeria, Peru, the Philippines, Venezuela, and Yugoslavia. See Rojas-Suárez (1991).

${ }^{37}$ See Conesa (1986), Cuddington (1986), Dooley (1988), and Meyer and Bastos-Márques (1989). 
with broader selections of financial instruments were also encouraged by the limited availability of domestic alternatives. Finally, incentives for enterprises and individuals to maintain foreign exchange working balances abroad were sometimes created by restrictions on the purchase of foreign exchange in source countries.

The curtailment of external bank lending that began in 1982 obviously affected many heavily indebted developing countries. Capital flight worsened this situation in a number of ways. ${ }^{38}$ Resulting capital outflows created inflationary pressures by expanding fiscal imbalances as tax bases were eroded and debt-servicing costs rose. Inflationary pressures were also aggravated by the depreciation of exchange rates that followed capital outflows. In response to these difficulties, several countries implemented policies designed to attain macroeconomic stability and eliminate structural distortions, with a view to re-establishing confidence in the domestic economy, re-opening international capital markets, and encouraging the return of flight capital. As discussed previously, Chile, Mexico, and Venezuela, in particular, have in recent years recorded notable progress in this regard. Countries that have moved toward re-establishing confidence have (1) implemented adjustment policies aimed at reducing financial imbalances and inflation through better monetary and fiscal policy mixes; (2) sought to establish well-functioning markets for labor, goods, money, and foreign exchange, with wages, prices, interest rates, and an exchange rate generally in line with underlying demand and supply conditions; (3) pursued other structural reforms, such as trade liberalization and deregulation of domestic financial markets; and (4) restructured their external debt with a view to eliminating its potential disincentive effects on investment.

While the implementation of stabilization policies has been necessary to reverse capital flight, other measures or techniques have proven useful in accelerating or supporting the process. These have ranged from changes in tax policies to the reform of rules governing foreign direct investment. ${ }^{39}$ The following discussion reviews some of these mechanisms used to reverse capital flight.

\section{Measures to Reverse Capital Flight}

\section{Amnesties}

Amnesties attempt to repatriate flight capital that has remained abroad in order to avoid specific legal

\footnotetext{
${ }^{38}$ This view implicitly assumes that the bulk of capital flight resources, if retained domestically, would have been used for growth-inducing domestic investment. For a criticism of this view, see Gordon and Levine (1989).

${ }^{39}$ These issues have been developed further in Brewer (1991), Cockcroft and Riddell (1991), Inotai (1991), and Wallace (1990).
}

consequences. By excusing, for example, past violations of exchange control regulations and taxes on investment income, inflows of foreign exchange have been stimulated and, to a lesser degree, future tax bases have been broadened. ${ }^{40}$ To be successful, amnesties aimed at repatriating private capital must be implemented in conjunction with reducing or eliminating the original incentives for capital flight. Note that a 1982 amnesty in France failed, in part owing to the continued existence of a wealth tax. A second attempt in 1986-considered a success because it led to the repatriation of an estimated $\$ 1.6$ billion - was implemented in conjunction with a repeal of the wealth tax, a reduction of the tax rate on repatriated capital, and the elimination of remaining capital controls. Experience has also shown that the success of amnesties is sensitive to any disincentives arising from their combination with other schemes. The 1987 Argentine amnesty, in conjunction with a debtequity program, exempted from taxes all previously unreported income to be used for domestic investment purposes. But it required matching converted debt with new money. The unattractiveness of this one-to-one rule outweighed the benefits of the program and failed to induce repatriation, notwithstanding the tax exemption.

An amnesty may be of limited or extended duration. For developing countries, amnesties of limited duration are unlikely to have an enduring impact. Amnesties of longer duration generally appear to have had a greater effect and are the logical policy accompaniment to the liberalization of capital accounts. The Government of Mexico has had a standing amnesty since 1989. A stamp tax of 2 percent is assessed on repatriated capital in conjunction with an exemption for past tax evasion on interest income. Chile has an implicit standing amnesty since no questions are asked concerning the source of the repatriated foreign exchange used under Chapter XVIII of the country's foreign exchange regulations. Similarly, Costa Rica encourages the repatriation of flight capital by permitting domestic foreigncurrency-denominated deposits or local-currencydenominated certificates of deposits to be redeemed in foreign currency at maturity.

\section{Capital Account Liberalization}

The elimination of capital controls on outflows may induce capital repatriation to the extent that it reassures residents of their ability to "re-export" their financial holdings in the event of worsening

\footnotetext{
${ }^{40} \mathrm{Tax}$ amnesties have also been used for purposes of collecting domestic corporate and income tax revenue from delinquent enterprises and individuals. See Internal Revenue Service (1987), Leonard and Zeckhauser (1986), Stella (1989), and Uchitelle (1989).
} 
economic conditions. Repatriation would also be encouraged to the extent that capital account liberalization is viewed by the market as a positive signal as to the underlying improvement in the economic situation and the authorities' commitment to maintain appropriate policies. In the case of Chile, which has experienced significant capital repatriation, a parallel market for foreign exchange was transformed into a legal informal exchange market in 1990, when new regulations permitted all foreign exchange transactions other than those explicitly restricted by the Central Bank. In Peru, the liberalization of the capital account initiated in mid-1990 and followed up in early 1991 -in conjunction with a comprehensive stabilization program-has been associated with private capital inflows exceeding $\$ 1$ billion. Argentina has experienced several reversals in privatesector capital flows in the recent past, in line with changing expectations concerning the durability of stabilization policies; the fluidity of these capital movements is largely a result of relatively liberal capital and exchange control regimes. Similarly, in Uruguay, limited capital controls have attracted significant private capital flows.

\section{Foreign-Currency-Denominated Domestic Instruments}

Since exchange risk can provide an incentive for capital flight, some countries have allowed domestic assets, especially bank deposits and bonds, to be denominated in foreign currency. In addition to protecting residents' holdings from unanticipated devaluations, such assets may also provide greater liquidity than assets held abroad. Foreign currency deposits have been prevalent in countries that have experienced episodes either of high inflation or currency overvaluation (for example, Egypt, Israel, Turkey, Yugoslavia, and most Latin American countries). Foreign-currency-denominated bonds have been issued in recent years in Argentina, Colombia, Mexico, Pakistan, and Uruguay.

Foreign currency assets may, however, have costly side-effects resulting from currency substitution. Such assets legalize and, other things being equal, encourage such substitution by decreasing the costs of obtaining foreign-currency-denominated assets outside the country. The negative implications of currency substitution are well documented; they involve weakened effectiveness of monetary policy, larger public-sector deficits because of reduced seigniorage, and higher central bank or commercial bank losses. ${ }^{41}$ These potential complications suggest

\footnotetext{
${ }^{41}$ The two effects on the public-sector deficit depend, respectively, on the rate of inflation and the extent to which exchange rates are depreciated in real terms and interest rates are forced to a level below the inflation rate. See Dodsworth, El-Erian, and Hamman (1987) and Fischer (1987) on currency substitution and
}

that the use of foreign currency deposits be limited, either through preferential yields on domesticcurrency-denominated assets or restraints on their share of total domestic financial liabilities. To the extent that capital flight has already occurred, foreign-currency-denominated instruments may lead to the repatriation of flight capital only if additional incentives are present, usually in the form of an interest rate premium with respect to the haven country.

\section{Offshore Securities}

Foreign-currency-denominated instruments placed in the international capital markets by developing countries, such as those that have recently reentered those markets, can tap the offshore holdings of residents hesitant to repatriate their savings because of transfer risk considerations. Such securities have a number of attractions for residents holding flight capital. First, the foreign currency denomination eliminates exchange rate risk relative to the domestic currency. Second, the assets provide anonymity and eliminate confiscation risk. This is accomplished by means of issuing bearer, rather than registered, bonds through foreign intermediaries. For equities, country funds can serve a similar purpose. Third, the tendering of securities in foreign markets limits the threat of discrimination against investors who are residents. Fourth, in the event that the countries in which the offshore security is placed tax on source rather than residency principles, the returns on such investments would not be subject to taxation back home. Similarly, the existence of bilateral tax treaties may limit the possibility of double taxation of interest income.

\section{Debt Conversions}

Debt conversion schemes may also promote the repatriation of flight capital to the extent that they provide attractive vehicles for acquiring domestic equity. ${ }^{42}$ The most common schemes involve exchange of debt for equity and debt for other domestic currency assets. For debt-equity conversions to provide vehicles for the repatriation of flight capital, residents must be permitted to participate through, for example, implicit or explicit amnesties, since they will be purchasing a registered instrument through an official intermediary. Alternatively, external intermediaries may be used, such as specific country funds. The attractiveness of such exchanges may be enhanced if the conversion is part of a program to

foreign currency deposits, respectively, and El-Erian (1988), Ortiz (1983), and Ramírez-Rojas (1985) for case studies.

${ }^{42}$ The attractiveness of such schemes will depend primarily on the conversion terms relative to those faced in obtaining the debt on the secondary market. 
privatize viable public enterprises. ${ }^{43}$ Several recent examples of debt-equity conversions associated with privatization programs may be found in Argentina, Mexico, Nigeria, and the Philippines. In Argentina, a Private Development Trust fund-whose objective is the privatization of 13 public enterprises-has been designed to permit residents to repatriate flight capital through the anonymous intermediation of foreign commercial banks. Similar funds are being

\footnotetext{
${ }^{43}$ Such a combination also provides authorities with the added advantage that the conversion will not lead to additional domestic liquidity creation since the counterpart of the new investments will accrue to the governments.
}

developed in other countries, for example, the offshore South Andean Investment Fund in Chile and the Plan for Privatization and Development in Brazil. Residents have been allowed to participate in many such debt-equity conversions without discrimination. In Chile, however, residents participate in a separate program, under Chapter XVIII of current foreign exchange regulations. The Central Bank auctions the right to repurchase discounted debt bought in the secondary market with foreign exchange acquired either on the parallel market or from abroad. Despite intentional limitations on this program for monetary control reasons, it has nevertheless facilitated the repatriation of more than $\$ 3$ billion since its inception in 1986. 


\section{Commercial Bank Debt of Low-Income Countries}

T his chapter examines recent developments in external commercial bank financing for lowincome countries in light of the considerable attention recently focused on official bilateral support for heavily indebted low-income rescheduling countries. ${ }^{44}$ In late 1988 , for example, the Paris Club introduced concessional reschedulings using an options approach ("Toronto terms") for low-income countries. More recently, the communiqué of the July 1991 Group of Seven economic summit recognized that there is a need on a case-by-case basis for additional debt relief measures for low-income countries going well beyond the relief already granted under Toronto terms. A comprehensive resolution of the debt problems of heavily indebted low-income countries, however, will need to focus on the appropriate restructuring of not only official bilateral debt but also of debt to commercial creditors. In this connection, this chapter reviews the status of relations between low-income debtors and their commercial creditors.

\section{Background}

Commercial banks have played a relatively small and declining role in the external financing of lowincome countries. At the end of 1990 , commercial banks held an estimated $\$ 12.7$ billion in claims on low-income countries, equivalent to about 10 percent of their total debt (excluding liabilities to the IMF). ${ }^{45}$ This proportion represents a decline of more than 4 percentage points since 1983 , owing in part to the gradual transfer of claims guaranteed by

\footnotetext{
${ }^{44}$ In this chapter, the term "low-income countries" refers to the group of small low-income economies in the IMF's May 1991 World Economic Outlook classification of countries, and thus excludes China and India. Although Bolivia is not classified in this category in the World Economic Outlook classification, it is included in this analysis because it is eligible for financing from the International Development Agency's debt reduction facility. Aggregate data presented for this group are taken from the World Economic Outlook, supplemented where necessary by data from the World Bank's World Debt Tables, 1990-91.

${ }^{45}$ Although the discussion in this chapter focuses mainly on low-income countries' commercial bank debt, these countries' commercial debt also includes debts to private nonguaranteed suppliers. In many low-income countries, however, a lack of data makes it difficult to distinguish among various categories of private creditors.
}

export credit agencies from the books of commercial banks to the books of the official guarantee agencies in creditor countries. More fundamentally, new commercial bank lending to low-income countries, at all maturities, has been stagnant since the mid-1980s. Commercial bank claims on these countries has in fact risen by only $\$ 1.5$ billion between 1985 and 1989 , and most of this amount is associated with increasing interest arrears. Data on scheduled debt-service payments to banks are only partially available. Indications are, however, that although this debt constitutes a relatively small portion of the total external debt of low-income countries, it may nevertheless account for a sizable portion of interest due in many countries because of its nonconcessional terms. In 1989, the latest year for which aggregate information is available, actual cash debt-service payments (principal and interest) on commercial bank claims is estimated at about $\$ 0.6$ billion, or some 13 percent of total debt service paid.

Situations of individual low-income countries vary widely, and the origins and effects of current debt problems are not uniform. For example, although several low-income countries have had repeated reschedulings with official and/or commercial bank creditors over the last decade, others have been able to service their debts in full by pursuing prudent economic and debt management policies and receiving certain types of assistance. In addition, some countries are indebted almost exclusively to official creditors and their debt is mainly on concessional terms, whereas others have substantial debts to commercial creditors. Moreover, despite concluding rescheduling agreements with commercial banks, some countries have been unable to make full payments on a regular basis; as a result, arrears on various categories of debt have accumulated. Although commercial bank claims make up only a small share of these countries' total debt, the impact is magnified not only by their nonconcessional nature but also because arrears on these claims can adversely affect access to, or the terms of, short-term trade credits. In addition, it may be difficult to attract domestic or foreign investment in countries where bank debt is quoted on the secondary market at a deep discount. To resolve the debt problems of these countries, it is therefore not sufficient to focus only on the appropriate restructuring of official bilateral claims; 
debts to private creditors must also be suitably restructured.

To assist in resolving the debt problems of heavily indebted low-income countries, the International Development Agency of the World Bank established a debt reduction facility in 1989 with a transfer of $\$ 100$ million from World Bank income. The facility can make grants of up to $\$ 10$ million to countries that satisfy certain requirements. The proceeds, along with any cofinancing from other donors, can be used to buy back or exchange debt at a marketrelated discount. To obtain support from the facility, the operational guidelines require countries to adopt appropriate adjustment programs and overall debt strategies that offer the prospect of materially enhancing growth and development prospects. In addition, the country's debt strategy is required to include a program for comprehensively resolving commercial debt problems.

\section{Country Circumstances}

Although considerable diversity is evident in the relations of low-income countries and their commercial bank creditors, three broad groups of countries may be identified. These illustrative groups highlight some common features regarding commercial bank debt, although within each group the countries remain heterogeneous, especially with regard to their economic performance and prospects.

A first group of countries (including, for example, Bangladesh, Ethiopia, Ghana, Kenya, Pakistan, and Sri Lanka) have serviced their commercial bank debts in full and have avoided rescheduling. These countries have maintained access to spontaneous long-term credits from commercial banks as well as to short-term trade and interbank credits. In 1990, for example, Bangladesh, Ethiopia, Ghana, Kenya, and Pakistan received an estimated $\$ 0.6$ billion in spontaneous long-term bank loan commitments. Loans to the state-owned international airlines in Bangladesh and Ethiopia account for more than half of the total amount committed in 1990. (Available information suggests that the spreads over LIBOR were in the range of $3 / 4$ to $1 \frac{1}{1 / 2}$ percent, with maturities of between 10 and 15 years.)

Despite such significant spontaneous bank loan commitments in 1990, total long-term bank claims on Bangladesh, Ethiopia, Ghana, and Pakistan fell between 1988 and 1990. During the same period, the short-term claims of commercial banks on Bangladesh, Kenya, and Pakistan rose sharply, from $\$ 1.5$ billion in 1988 to $\$ 2.5$ billion in 1990. After heavy short-term bank borrowing in 1987-88, Sri Lanka largely repaid these debts over the next two years as its balance of payments situation improved. Such patterns of short-term versus long-term lending to nonrescheduling countries would seem to suggest that banks consider short-term loans to be more senior, in part because they are generally excluded from rescheduling agreements. Asset-based long-term lending is, however, relatively common as banks have shown a willingness to finance high-value moveable assets, on which liens can be attached.

A second group of countries-including, for example, The Gambia, Madagascar, Malawi, Senegal, and Togo-have had temporary difficulties servicing their bank debts and have needed to reschedule. Following restructurings, these countries have generally kept current on interest payments. Indeed, some of the countries in this group have already graduated from debt rescheduling to normal debtorcreditor relations. Nevertheless, for several the discount on commercial bank claims in the secondary market remains at approximately $50-60$ percent and they have not been able to attract spontaneous longterm bank loans. ${ }^{46}$

Finally, a third group comprises countries that face extremely difficult financing situations in the face of protracted arrears problems. The countries in this category include Bolivia, Guinea, Guyana, Mozambique, Sierra Leone, Somalia, Sudan, Tanzania, Viet Nam, Zaïre, and Zambia. Some of these countries have rescheduled their bank debts in the past but have fallen into arrears since then. Secondary market discounts for bank claims on these countries are generally 80 percent or higher. Several countries in this group are also in arrears to the Fund, and progress toward a resolution of the commercial bank debt problem is pending a clearance of overdue obligations to the Fund and other official creditors. For these countries, interest arrears on long-term debt to commercial banks (excluding those on claims guaranteed by official export credit agencies) are estimated to have risen from $\$ 1$ billion at the end of 1988 to about $\$ 1.5$ billion at present. Apart from a small increase in short-term trade credit, commercial banks have not provided new credit to these countries on a net basis since the mid-1980s.

Countries in the second and third groups have generally been able to maintain some access to short-term loans, but systematic data on the terms of such borrowings are not available. Partial data suggest that in some countries banks have moved away from unsecured lending and now require some form of offshore security to mitigate transfer risk. For example, export-secured lending, using a variety of mechanisms, is particularly prevalent in countries that have experienced debt-servicing difficulties. A common form of export-secured lending is preexport finance, and banks have provided substantial facilities, which have essentially provided balance of

\footnotetext{
${ }^{46}$ The secondary market for bank claims on low-income countries is reportedly very thin, with few and infrequent transactions and relatively wide spreads between bid and offer prices.
} 
payments support, to several low-income countries, including Tanzania, Uganda, and Sudan. ${ }^{47}$ Of the countries in the second and third groups, Guinea, Guyana, Senegal, Sudan, and Zambia have had an increase in short-term debt to banks-mostly secured facilities - between 1988 and 1990, averaging about $\$ 130$ million a year for all of these countries. In others-including Madagascar, Malawi, Mozambique, Sierra Leone, Tanzania, Togo, Uganda, and Zaïre-commercial bank short-term claims have been maintained or declined modestly during the same period.

\section{Bank Debt Restructurings by Low-Income Countries}

Since 1983, 13 low-income countries have reached either restructuring or deferment agreements with commercial banks: The Gambia, Guinea, Guyana, Madagascar, Malawi, Mozambique, Niger, Senegal, Sierra Leone, Sudan, Togo, Zaïre, and Zambia. Some of these countries (Guyana, Madagascar, Niger, Senegal, Sudan, and Zaïre) have had more than one restructuring or deferment agreement during this period. The debt covered by these agreements amounts to $\$ 2$ billion, of which about half is accounted for by the 1984-85 Sudan restructurings. In recent years, however, there has been only limited progress in the restructuring of low-income countries' bank debt, and, as noted earlier, many of these countries have accumulated arrears on commercial bank claims. The small number of bank financing packages contrasts with the active rescheduling of these countries' official bilateral debt under Paris Club auspices. ${ }^{48}$ Specifically, during the last two years, Madagascar and Senegal have signed rescheduling agreements with commercial banks, Zaïre signed a deferment agreement, and Niger concluded a bank debt reduction operation. Claims covered by all of these agreements amount to $\$ 230$ million. In some other cases, such as Bolivia and Mozambique, progress toward regularization has occurred through negotiations on buy-backs and other debt reduction instruments.

In general, the terms for bank debt restructurings for low-income countries have been less favorable than those obtained by middle-income countries. Specifically, the spread over LIBOR of renegotiated debt during $1987-89$ ranged from $1 \frac{1}{8}$ to $1^{7 / 8}$ percent,

\footnotetext{
${ }^{47}$ The mechanisms of export-secured lending include assignment of a title to exports, the issuance of irrevocable instructions to a buyer to make payments directly to a lending bank, or the establishment of foreign exchange escrow accounts.

${ }^{48}$ Since the first Toronto terms rescheduling with Mali in late October 1988, 20 low-income countries have rescheduled \$6 billion of debt-service obligations in 28 agreements with Paris Club creditors. For several of these countries, debts to private creditors are negligible, and a restructuring of these debts was not being sought.
}

with maturities typically less than ten years. In contrast, spreads on middle-income country bank debt restructurings (other than trade facilities) during this same period were typically $13 / 16$ to $7 / 8$ percent over LIBOR, with maturities generally over 12 years. Note, however, that two middle-income countries in Africa-Côte d'Ivoire and Gabon-rescheduled at spreads of $1^{1 / 4}$ to $1^{3 / 8}$ percent, while Nigeria obtained a spread of $13 / 16$ percent in 1989.49 In the 1990 restructuring agreements for Madagascar and Senegal, for example, the spreads were $7 / 8$ percent, though the maturity was nine years.

In addition to these reschedulings, a distinct approach was that for Bolivia, where grants from bilateral donors were used to buy back $\$ 253$ million of commercial bank debt at face value in early 1988 . The buy-back, which also eliminated associated interest arrears, took place at a preannounced price of 11 cents on the dollar. Since that initial transaction, Bolivia has eliminated a further $\$ 227$ million of its commercial bank debt through collateralized debt exchanges with principal reduction, thus eliminating about 70 percent of commercial bank debt and about 8 percent of total debt.

Niger was the first country to benefit from the IDA debt reduction facility when, in December 1990, the Executive Board of IDA approved a $\$ 10$ million grant to support a debt reduction operation. This amount was supplemented by a matching grant of $\$ 10$ million from France and an additional $\$ 3$ million from Switzerland. The funds were received by the Central Bank of West African States on behalf of Niger and were used in February 1991 to collateralize fully its guarantee of instruments issued by Niger in exchange for commercial bank debt. The implicit price of the transaction was 18 cents per dollar of the old debt at face value. The transaction effectively eliminated Niger's \$111 million of commercial bank debt and related interest arrears. Several other potential IDA-financed operations, including operations for Bolivia and Mozambique, are under preparation. In the case of Mozambique, approval by the IDA Board was obtained in mid-June 1991, and substantial progress has been made toward a buy-back of about $\$ 323$ million of debt arrears to commercial banks.

The agreement with Niger and progress in these other low-income cases may signal some abatement in the apparent reluctance of banks to agree to debt operations at relatively large discounts on country exposures that are heavily provisioned and represent a small portion of their loan portfolios. In addition

\footnotetext{
${ }^{49}$ Spreads of $13 / 16$ percent over LIBOR became almost standard for most middle-income countries following the September 1986 agreement in principle (finalized in April 1987) between Mexico and its bank creditors. Smaller middle-income countries, such as Honduras and Jamaica, however, faced spreads of $1^{1 / 3}$ and $1^{1 / 4}$ percent, respectively, for their 1987 bank debt reschedulings.
} 
to the apparent low priority placed by banks on reaching agreement with low-income countriesand because of concerns about creating undesired precedents-progress is often handicapped by debtor countries' inadequate information on the extent of commercial bank claims, especially after a period of protracted arrears; by human resource constraints in preparing appropriate debt strategies; and by legal issues.

\section{Debt Swaps}

As discussed earlier, international agencies and relief organizations have shown increasing interest in debt conversion programs as a means of reducing commercial bank claims on developing countries and channeling funds to certain causes. Beginning in 1987, debt-for-nature and debt-for-development swaps (primarily in the agricultural, health, and education sectors) have taken place in at least four lowincome countries: Bolivia, Madagascar, Sudan, and Zambia. These swaps have reduced those countries' commercial bank debts by an estimated $\$ 10$ million. Such schemes have tended to involve the purchase of bank debt at a discount in the secondary market by a charitable organization, although in some instances banks have donated their claims to charitable groups. These debts are then converted into local currency instruments, generally at a smaller discount than prevailing in the secondary market; and even at par in some cases. A number of organizations are reportedly exploring the potential for expanding this approach by establishing debt conversion funds. For the debtor country's public sector, two expenditure components are effectively involved: a conversion into local currency of the debt acquired by the charitable organization, and a contribution to the given project's financing. The differential between the discounts obtained by the charitable organization in the secondary market and that applied when the debt is converted into local currency determine the incremental cost faced by the public sector when compared to the alternative, if available, of purchasing the debt directly. In addition, the project financed may entail future recurrent expenditures for the debtor country's public sector. Integrating conversion approvals into the normal budgetary and monetary programming process could help, among other things, ensure the efficiency of the public sector's effective contribution to the project's financing.

The Bolivian debt-for-nature swap program, launched in July 1987, involved the exchange of commercial bank claims for local currency to fund the management of ecological resources and demarcate tropical forest land as a protected area. In 1988 and 1989, certain banks donated their claims on Sudan to UNICEF, and the proceeds from the conversion of these claims into local currency at a discount have been used to finance health care, water supply, and tree planting projects in central Sudan. Similar projects have been undertaken in Bolivia and Zambia, with resources from the official sector used to acquire claims on the secondary market for the purpose of making charitable donations. Other recent operations include nature and environmental projects in Madagascar (involving, in separate transactions, the World Wildlife Fund and Conservation International) and health projects in Sudan. 
This page intentionally left blank 


\section{Statistical Appendix}


This page intentionally left blank 


\begin{tabular}{|c|c|c|c|c|c|c|c|}
\hline & 1985 & 1986 & 1987 & 1988 & 1989 & 1990 & $\begin{array}{c}\text { First } \\
\text { Quarter } \\
1991\end{array}$ \\
\hline Total change in claims ${ }^{2}$ & 217 & 450 & 660 & 480 & 653 & 479 & - \\
\hline $\begin{array}{l}\text { Industrial countries } \\
\text { Of which: }\end{array}$ & \multicolumn{6}{|c|}{ Of which: } & 14 \\
\hline United States & 33 & 69 & 83 & 69 & 59 & 16 & -12 \\
\hline Japan & 40 & 148 & 192 & 185 & 136 & 47 & -54 \\
\hline Developing countries $^{3}$ & 8 & 4 & 16 & -2 & - & 9 & 5 \\
\hline Offshore centers ${ }^{4}$ & 19 & 81 & 163 & 82 & 171 & 112 & -18 \\
\hline Other transactors 5 & 7 & -11 & 15 & 8 & 30 & -20 & -2 \\
\hline \multicolumn{8}{|l|}{ Memorandum items } \\
\hline Capital-importing developing countries ${ }^{3,6}$ & 8 & 4 & 14 & -6 & -2 & 8 & 7 \\
\hline Non-oil developing countries ${ }^{3,7}$ & 6 & 4 & 14 & -8 & 5 & 6 & 8 \\
\hline Fifteen heavily indebted countries & - & -1 & 2 & -10 & -3 & -9 & 2 \\
\hline Total change in liabilities ${ }^{8}$ & 213 & 466 & 625 & 445 & 651 & 432 & -60 \\
\hline Industrial countries & 168 & 364 & 439 & 327 & 464 & 384 & -23 \\
\hline \multicolumn{8}{|l|}{ Of which: } \\
\hline United States & 8 & 56 & 35 & 63 & 61 & -1 & -14 \\
\hline Japan & 40 & 111 & 145 & 147 & 125 & 58 & -41 \\
\hline Developing countries $^{3}$ & 1 & -10 & 33 & 19 & 41 & 45 & -1 \\
\hline Offshore centers ${ }^{4}$ & 37 & 117 & 137 & 95 & 135 & 25 & -33 \\
\hline Other transactors $^{5}$ & 8 & -5 & 16 & 4 & 12 & -21 & -3 \\
\hline \multicolumn{8}{|l|}{ Memorandum items } \\
\hline Capital-importing developing countries ${ }^{3,6}$ & 5 & 2 & 25 & 12 & 36 & 50 & - \\
\hline Non-oil developing countries ${ }^{3.7}$ & 2 & 9 & 25 & 13 & 33 & 41 & -2 \\
\hline Fifteen heavily indebted countries & -3 & -7 & 5 & -1 & 7 & 13 & - \\
\hline Change in total net claims ${ }^{9}$ & 5 & -16 & 35 & 35 & 2 & 47 & 59 \\
\hline Industrial countries & 16 & 12 & 26 & 66 & -12 & -7 & 37 \\
\hline \multicolumn{8}{|l|}{ Of which: } \\
\hline United States & 25 & 13 & 48 & 6 & -2 & 17 & 3 \\
\hline Japan & -1 & 37 & 47 & 39 & 12 & -11 & -14 \\
\hline Developing countries $^{3}$ & 7 & 14 & -17 & -20 & -41 & -35 & 6 \\
\hline Offshore centers ${ }^{4}$ & -18 & -36 & 26 & -14 & 36 & 87 & 15 \\
\hline Other transactions 5 & -1 & -5 & -1 & 4 & 18 & 2 & 1 \\
\hline \multicolumn{8}{|l|}{ Memorandum items } \\
\hline Capital-importing developing countries ${ }^{3.6}$ & -3 & 2 & -10 & -18 & -38 & -42 & 7 \\
\hline Non-oil developing countries ${ }^{3,7}$ & 5 & -5 & -12 & -22 & -37 & -34 & 10 \\
\hline Fifteen heavily indebted countries & 3 & 6 & -3 & -9 & -10 & -22 & 2 \\
\hline Net errors and omissions 10 & -5 & 16 & -35 & -35 & -2 & -47 & -59 \\
\hline
\end{tabular}

Sources: International Monetary Fund, International Financial Statistics (IFS); and IMF staff estimates.

'Data on changes in claims and liabilities are derived from stock data on the reporting countries' liabilities and assets, excluding changes attributed to exchange rate movements.

${ }^{2}$ As measured by differences in the outstanding liabilities of borrowing countries, defined as cross-border interbank accounts by residence of borrowing bank.

'Excluding offshore centers.

${ }^{4}$ The Bahamas, Bahrain, the Cayman Islands, Hong Kong, the Netherlands Antilles, Panama, and Singapore.

"Transactors included in IFS measures for the world, to enhance global symmetry, but excluded from IFS measures for "All Countries." The data comprise changes in the accounts of the Bank for International Settlements with banks other than central banks and changes in identified cross-border interbank accounts of European developing economies (excluding IMF members).

${ }^{6}$ All developing countries except the eight Middle Eastem oil exporters (the Islamic Republic of Iran, Iraq, Kuwait, the Libyan Arab Jamahiriya, Oman, Qatar, Saudi Arabia, and the United Arab Emirates) for which external debt statistics are either not available or are small in relation to external assets.

7All developing countries except the eight Middle Eastern oil exporters (listed in footnote 6), Algeria, Indonesia, Nigeria, and Venezuela.

" As measured by differences in the outstanding assets of depositing countries, defined as cross-border interbank accounts by residence of lending banks.

${ }^{9}$ Difference between changes in claims and liabilities.

I0The difference between global measures of cross-border changes in interbank claims and liabilities. 
Table A2. Change in Claims on Nonbanks

and Liabilities to Nonbanks, 1985-First Quarter $1991^{1}$

(In billions of U.S. dollars)

\begin{tabular}{|c|c|c|c|c|c|c|c|}
\hline & 1985 & 1986 & 1987 & 1988 & 1989 & 1990 & $\begin{array}{c}\text { First } \\
\text { Quarter } \\
1991\end{array}$ \\
\hline Total change in claims ${ }^{2}$ & 60 & 88 & 139 & 74 & 187 & 263 & 52 \\
\hline Industrial countries & 25 & 38 & 79 & 81 & 120 & 204 & 25 \\
\hline \multicolumn{8}{|l|}{ Of which: } \\
\hline United States & 21 & 25 & 23 & 39 & 35 & 49 & 2 \\
\hline Japan & - & 5 & 31 & 18 & 36 & 54 & 1 \\
\hline Developing countries $^{3}$ & -4 & -2 & 6 & -3 & 11 & -6 & 7 \\
\hline Offshore centers ${ }^{4}$ & 10 & 5 & 1 & 3 & 10 & 16 & -4 \\
\hline Other transactors ${ }^{5}$ & 3 & 4 & 2 & - & 3 & 9 & 2 \\
\hline Unidentified borrowers ${ }^{6}$ & 26 & 43 & 51 & -7 & 43 & 41 & 21 \\
\hline \multicolumn{8}{|l|}{ Memorandum items } \\
\hline Capital-importing developing countries ${ }^{3.7}$ & -3 & -1 & 7 & -3 & 8 & -3 & 4 \\
\hline Non-oil developing countries ${ }^{3,8}$ & -3 & -1 & 8 & -1 & 10 & - & 8 \\
\hline Fifteen heavily indebted countries & -5 & -1 & 1 & -5 & - & -19 & -1 \\
\hline Total change in liabilities ${ }^{9}$ & 88 & 118 & 135 & 95 & 161 & 213 & 12 \\
\hline Industrial countries & 27 & 60 & 53 & 50 & 107 & 116 & 37 \\
\hline \multicolumn{8}{|l|}{ Of which: } \\
\hline United States & 14 & 26 & 23 & 21 & 6 & 25 & 1 \\
\hline Japan & 1 & 2 & 1 & 2 & 13 & -3 & - \\
\hline Developing countries ${ }^{3}$ & 22 & 3 & 15 & 18 & 34 & 27 & -6 \\
\hline Offshore centers ${ }^{4}$ & 9 & 13 & 7 & 5 & 13 & 18 & -4 \\
\hline Other transactors 5 & 1 & -1 & 1 & 2 & 1 & 2 & 2 \\
\hline Unidentified depositors ${ }^{6}$ & 30 & 42 & 58 & 20 & 6 & 50 & -17 \\
\hline \multicolumn{8}{|l|}{ Memorandum items } \\
\hline Capital-importing developing countries ${ }^{3.7}$ & 16 & 6 & 11 & 13 & 23 & 21 & -3 \\
\hline Non-oil developing countries 3.8 & 14 & 7 & 11 & 12 & 20 & 20 & -3 \\
\hline Fifteen heavily indebted countries & 8 & 2 & 5 & 6 & 10 & 8 & -1 \\
\hline Change in total net claims on ${ }^{10}$ & -27 & -29 & 3 & -22 & 26 & 50 & 40 \\
\hline Industrial countries & -1 & -22 & 25 & 31 & 13 & 88 & -12 \\
\hline \multicolumn{8}{|l|}{ Of which: } \\
\hline United States & 8 & -1 & 1 & 19 & 28 & 24 & 1 \\
\hline Japan & -1 & 3 & 30 & 16 & 22 & 57 & 1 \\
\hline Developing countries $^{3}$ & -26 & -5 & -9 & -21 & -23 & -33 & 13 \\
\hline Offshore centers ${ }^{4}$ & - & -8 & -6 & -2 & -4 & -2 & - \\
\hline Other transactors ${ }^{5}$ & 2 & 5 & 1 & -2 & 3 & 7 & 1 \\
\hline Unidentified (net) ${ }^{6}$ & -3 & 1 & -7 & -27 & 37 & -9 & 38 \\
\hline \multicolumn{8}{|l|}{ Memorandum items } \\
\hline Capital-importing developing countries ${ }^{3,7}$ & -19 & -7 & -5 & -16 & -15 & -23 & 7 \\
\hline Non-oil developing countries ${ }^{3.8}$ & -16 & -8 & -3 & -13 & -10 & -19 & 10 \\
\hline Fifteen heavily indebted countries & -13 & -3 & -4 & -11 & -10 & -27 & - \\
\hline
\end{tabular}

Sources: International Monetary Fund, International Financial Statistics (IFS); and IMF staff estimates.

'Data on changes in claims and liabilities are derived from stock data on the reporting countries' liabilities and assets, excluding changes attributed to exchange rate movements.

${ }^{2}$ As measured by differences in the outstanding liabilities of borrowing countries, defined as cross-border bank credits to nonbanks by residence of borrower.

${ }^{3}$ Excluding offshore centers.

${ }^{4}$ The Bahamas, Bahrain, the Cayman Islands, Hong Kong, the Netherlands Antilles, Panama, and Singapore.

sTransactors included in IFS measures for the world, to enhance global symmetry, but excluded from IFS measures for "All Countries" The data comprise changes in the accounts of international organizations (other than the Bank for International Settlements) with banks; and changes in identified cross-border bank accounts of nonbanks in European developing economies (excluding Fund members).

'The difference between the amount that countries report as their banks' positions with nonresident nonbanks in their monetary statistics and the amounts that banks in major financial centers report as their positions with nonbanks in each country.

${ }^{7}$ All developing countries except the eight Middle Eastern oil exporters (the Islamic Republic of Iran, Iraq, Kuwait, the Libyan Arab Jamahiriya, Oman, Qatar, Saudi Arabia, and the United Arab Emirates) for which external debt statistics are either not available or are small in relation to external assets.

${ }^{8}$ All developing countries except the eight Middle Eastern oil exporters (listed in footnote 7), Algeria, Indonesia, Nigeria, and Venezuela.

${ }^{9}$ As measured by differences in the outstanding assets of depositing countries defined as international bank deposits by nonbanks by residence of depositor.

10Difference between changes in claims and liabilities. 
Table A3. Long-Term Bank Credit Commitments to

Developing Countries, 1984-First Quarter 19911

(In billions of U.S. dollars)

\begin{tabular}{|c|c|c|c|c|c|c|c|c|c|}
\hline & \multirow[b]{2}{*}{$1984^{2}$} & \multirow[b]{2}{*}{$1985^{3}$} & \multirow[b]{2}{*}{$1986^{4}$} & \multirow[b]{2}{*}{19875} & \multirow[b]{2}{*}{$1988^{6}$} & \multirow[b]{2}{*}{$1989^{7}$} & \multirow[b]{2}{*}{$1990^{8}$} & \multicolumn{2}{|c|}{ First Quarter } \\
\hline & & & & & & & & 1990 & 1991 \\
\hline Developing countries $^{9}$ & 29.2 & 16.0 & 22.8 & 16.4 & 17.5 & 18.2 & 17.8 & 3.4 & 2.6 \\
\hline Spontaneous lending & 12.7 & 13.8 & 14.7 & 14.1 & 11.8 & 15.9 & 16.6 & 2.2 & 2.6 \\
\hline Concerted lending 10 & 16.5 & 2.2 & 8.1 & 2.3 & 5.7 & 2.3 & 1.3 & 1.2 & - \\
\hline Capital importing countries ${ }^{9}$ & 28.1 & 14.4 & 21.4 & 16.3 & 17.2 & 16.8 & 17.8 & 3.4 & 2.6 \\
\hline Spontaneous lending & 11.6 & 12.2 & 13.3 & 14.0 & 11.5 & 14.5 & 16.6 & 2.2 & 2.6 \\
\hline Concerted lending $10^{\circ}$ & 16.5 & 2.2 & 8.1 & 2.3 & 5.7 & 2.3 & 1.3 & 1.2 & - \\
\hline Africa & 0.6 & 1.5 & 1.8 & 0.7 & 0.6 & 0.5 & 0.6 & 0.1 & - \\
\hline Spontaneous lending & 0.5 & - & 1.4 & 0.7 & 0.4 & 0.5 & 0.6 & 0.1 & - \\
\hline Concerted lending 10 & 0.1 & - & 0.4 & - & 0.2 & - & - & - & - \\
\hline Asia & 9.4 & 7.5 & 8.2 & 8.5 & 7.8 & 8.9 & 10.7 & 1.9 & 2.6 \\
\hline Spontaneous lending & 8.5 & 7.5 & 8.2 & 8.5 & 7.8 & 8.3 & 10.7 & 1.9 & 2.6 \\
\hline Concerted lending $10^{\circ}$ & 0.9 & - & - & - & - & 0.6 & - & - & - \\
\hline Europe & 1.6 & 2.8 & 2.8 & 4.1 & 2.2 & 2.7 & 1.7 & - & - \\
\hline Spontaneous lending & 1.6 & 2.8 & 2.8 & 4.1 & 1.9 & 2.7 & 1.7 & - & - \\
\hline Concerted lending $10^{\circ}$ & - & - & - & - & 0.3 & - & - & - & - \\
\hline Middle East & 0.4 & 0.3 & 0.1 & 0.3 & 0.2 & 0.7 & 0.1 & - & - \\
\hline Spontaneous lending & 0.4 & 0.3 & 0.1 & 0.3 & 0.2 & 0.6 & 0.1 & - & - \\
\hline Concerted lending 10 & - & - & - & - & - & 0.1 & - & - & - \\
\hline Western Hemisphere & 16.1 & 2.4 & 8.5 & 2.7 & 6.4 & 4.1 & 4.8 & 1.4 & - \\
\hline Spontaneous lending & 0.6 & 0.2 & 0.8 & 0.4 & 1.2 & $3.0^{11}$ & 2.711 & 0.2 & - \\
\hline Concerted lending $10^{\circ}$ & 15.5 & 2.2 & 7.7 & 2.3 & 5.2 & 1.1 & 2.1 & 1.2 & - \\
\hline \multicolumn{10}{|l|}{ Memorandum items } \\
\hline Other countries n.i.e. & 1.9 & 3.5 & 2.1 & 1.5 & 2.5 & 1.5 & 3.0 & - & - \\
\hline Offshore banking centers & 0.9 & $0.4^{12}$ & 0.7 & 0.3 & 0.4 & 2.4 & 3.0 & 0.2 & 0.7 \\
\hline $\begin{array}{l}\text { Sources: Organization for Econor } \\
\text { IOwing to rounding, components } \\
\text { 2Includes agreements in principle } \\
\text { 'Includes a \$0.1 billion revolving } \\
\text { 'Includes agreements in principle } \\
\text { SIncludes agreement in principle } \\
\text { 'Includes agreements in principle } \\
\text { TIncludes agreement in principle } \\
\text { 'Includes agreements in principle } \\
\text { 9Excludes offshore banking cente } \\
\text { 10 Concerted lending refers to ban } \\
\text { "Includes bank loans obtained } \\
\text { payments. } \\
{ }^{12} \text { Includes a \$0.1 billion concerte }\end{array}$ & $\begin{array}{l}\text { and Deve } \\
\text { Côte d'Iv } \\
\text { Costa Ri } \\
\text { Mexico, } \\
\text { re and Yu } \\
\text { inalized a } \\
\text { ind Urugr } \\
\text { ients coor } \\
6 \text { billion } \\
\text { ment to }\end{array}$ & $\begin{array}{l}\text { pment, Fin } \\
\text { re, Ecuado } \\
\text { id Nigeria. } \\
\text { oslavia. } \\
\text { eements w } \\
\text { y. } \\
\text { nated by a } \\
1989 \text { and } \\
\text { nama. }\end{array}$ & incial Stat & $\begin{array}{l}\text { tics Mont } \\
\text { tilippines }\end{array}$ & $\begin{array}{l}\text { ippines. } \\
\text { ee. } \\
\text { on a "se }\end{array}$ & staff estim & basis to & inance & acipal \\
\hline
\end{tabular}


Table A4. Bank Credit Commitments by

Country of Destination, 1984-First Quarter 1991 ${ }^{1}$

(In billions of U.S. dollars)

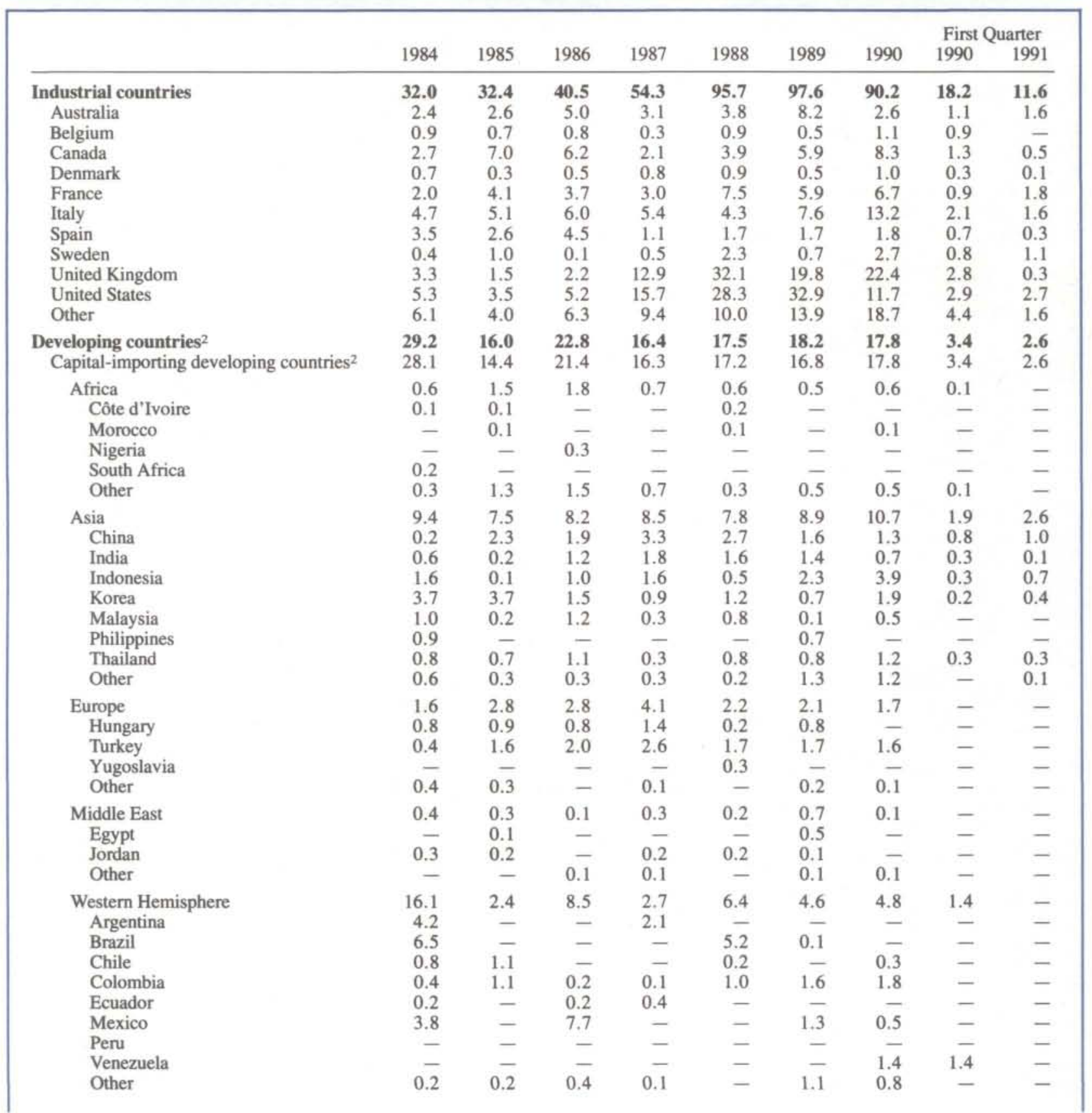


Table A4 (concluded).

\begin{tabular}{|c|c|c|c|c|c|c|c|c|c|}
\hline & & & & & & & & \multicolumn{2}{|c|}{ First Quarter } \\
\hline & 1984 & 1985 & 1986 & 1987 & 1988 & 1989 & 1990 & 1990 & 1991 \\
\hline Other countries n.i.e. ${ }^{3}$ & 1.9 & 3.5 & 2.1 & 1.5 & 2.5 & 1.5 & 3.0 & - & - \\
\hline Bulgaria & - & 0.5 & - & 0.3 & 0.1 & 0.3 & - & - & - \\
\hline Czechoslovakia & - & 0.1 & 0.3 & 0.2 & 0.2 & 0.3 & - & - & - \\
\hline U.S.S.R. & 0.9 & 1.5 & 1.3 & 0.8 & 2.2 & 0.9 & 3.0 & - & - \\
\hline Other & 1.0 & 1.5 & 0.5 & 0.2 & 0.1 & 0.1 & - & - & - \\
\hline Offshore banking centers & 0.9 & 0.4 & 0.7 & 0.3 & 0.4 & 2.4 & 3.0 & 0.2 & 0.7 \\
\hline International organizations and unallocated & 3.5 & 4.0 & 5.2 & 11.7 & 10.0 & 3.3 & 7.3 & 0.5 & 0.9 \\
\hline Total & 67.5 & 56.3 & 71.3 & 84.3 & 126.1 & 123.0 & 121.3 & 22.3 & 15.8 \\
\hline
\end{tabular}

Sources: Organization for Economic Cooperation and Development, Financial Statistics Monthly; and IMF staff estimates.

'OECD data on developing countries have been adjusted to include new money commitments under bank agreements in principle, as follows (amounts in billions of U.S. dollars):

1984: Argentina (3.7); Côte d'Ivoire (0.1); Ecuador (0.2); the Philippines (0.9).

1985: Costa Rica (0.1 revolving trade facility)

1986: Congo (0.1); Mexico (7.7); Nigeria (0.3)

1987: Ecuador $(0.4)$

1988: Côte d'Ivoire (0.2); Yugoslavia (0.3)

1989: Jordan (0.1); Mexico (1.1); the Philippines (0.7)

1990: Colombia (1.8); Uruguay (0.1); Venezuela (1.2)

${ }^{2}$ Excludes offshore banking centers.

Includes former German Democratic Republic through 1989. 


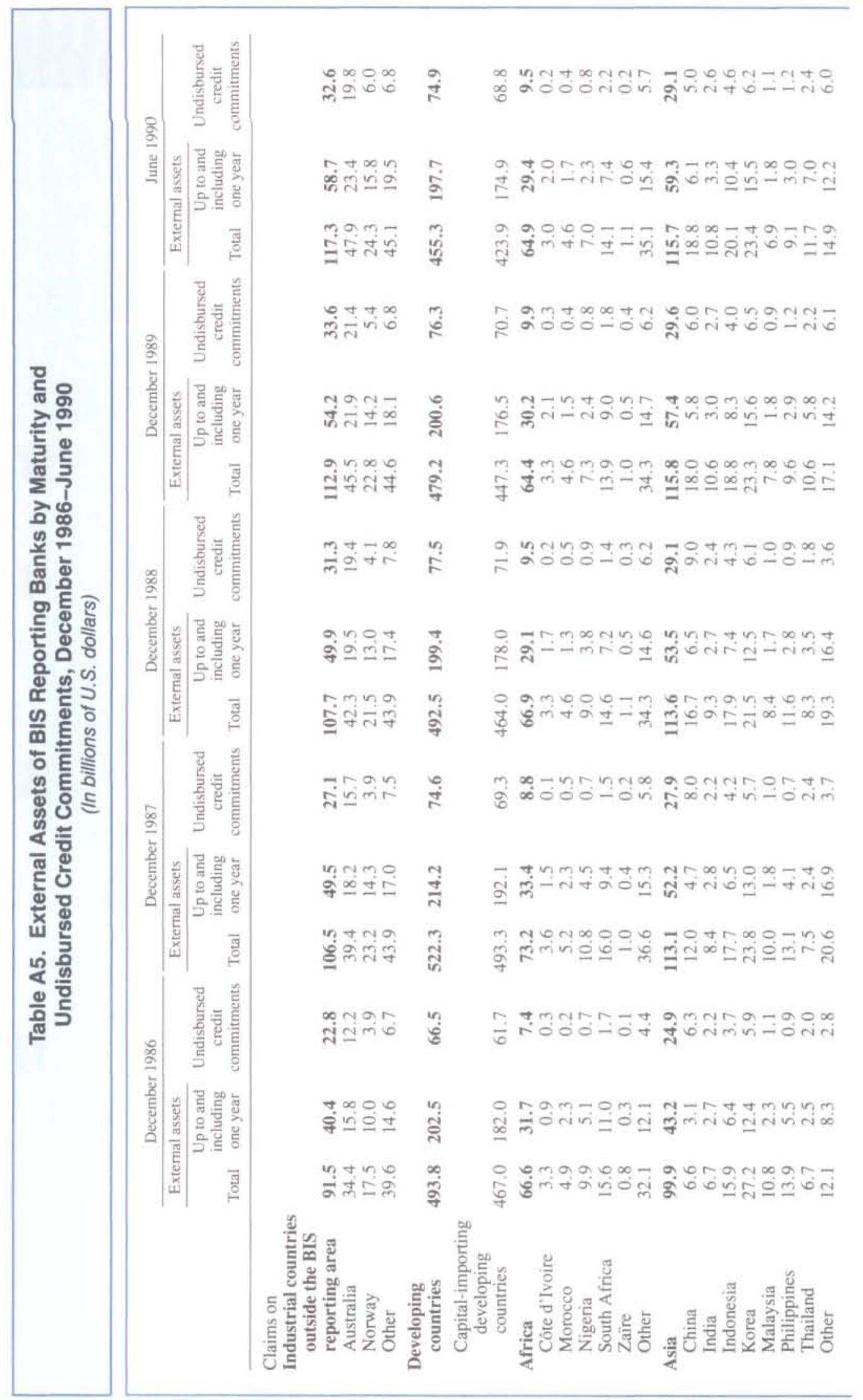




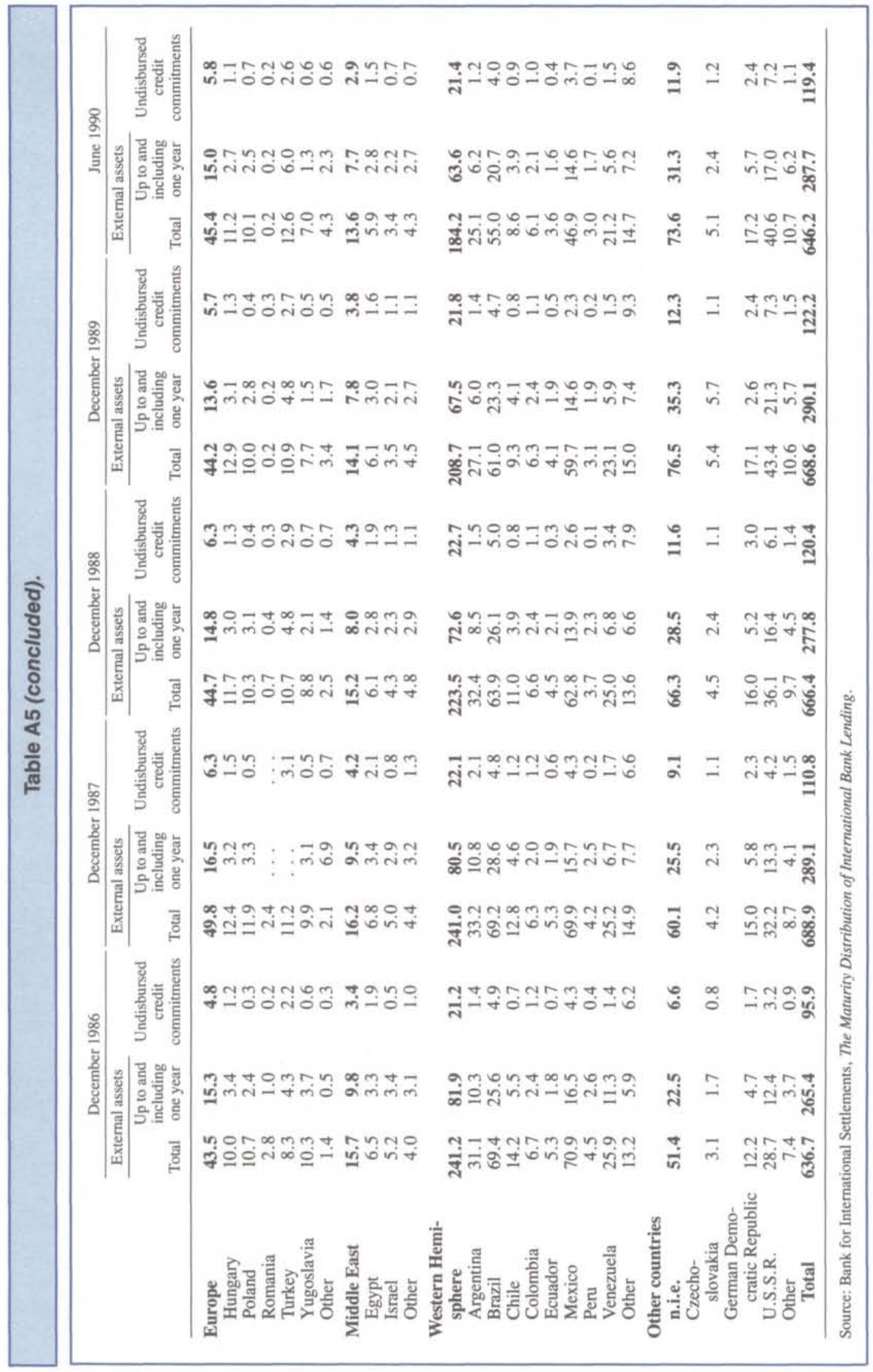


Table A6. Change in Claims of U.S. Banks on Developing Countries, 1985-901 (In billions of U.S. dollars, and in percent)

\begin{tabular}{|c|c|c|c|c|c|c|c|c|c|c|c|c|}
\hline & \multicolumn{2}{|c|}{1985} & \multicolumn{2}{|c|}{1986} & \multicolumn{2}{|c|}{1987} & \multicolumn{2}{|c|}{1988} & \multicolumn{2}{|c|}{$1989^{2}$} & \multicolumn{2}{|c|}{$1990^{2}$} \\
\hline & $\begin{array}{l}\text { Billion } \\
\text { U.S. } \\
\text { dollars }\end{array}$ & $\begin{array}{l}\text { Growth } \\
\text { rate }\end{array}$ & $\begin{array}{l}\text { Billion } \\
\text { U.S. } \\
\text { dollars }\end{array}$ & $\begin{array}{l}\text { Growth } \\
\text { rate }\end{array}$ & $\begin{array}{l}\text { Billion } \\
\text { U.S. } \\
\text { dollars }\end{array}$ & $\begin{array}{l}\text { Growth } \\
\text { rate }\end{array}$ & $\begin{array}{l}\text { Billion } \\
\text { U.S. } \\
\text { dollars }\end{array}$ & $\begin{array}{l}\text { Growth } \\
\text { rate }\end{array}$ & $\begin{array}{l}\text { Billion } \\
\text { U.S. } \\
\text { dollars }\end{array}$ & $\begin{array}{l}\text { Growth } \\
\text { rate }\end{array}$ & $\begin{array}{l}\text { Billion } \\
\text { U.S. } \\
\text { dollars }\end{array}$ & $\begin{array}{l}\text { Growth } \\
\text { rate }\end{array}$ \\
\hline \multicolumn{13}{|c|}{ Developing countries $^{3}$} \\
\hline All banks & -13.0 & -8.5 & -12.5 & -9.0 & -7.1 & -5.6 & -15.0 & -12.6 & -14.3 & -13.7 & -11.4 & -12.6 \\
\hline Nine banks & -7.1 & -7.5 & -7.7 & -8.7 & -4.3 & -5.4 & -7.5 & -9.9 & -7.0 & -10.2 & -5.9 & -9.6 \\
\hline Fifteen banks & -5.0 & -16.5 & -2.8 & -10.9 & -1.4 & -6.3 & -3.4 & -16.1 & -3.9 & -22.1 & -3.4 & -24.2 \\
\hline Others & -0.8 & -3.2 & -2.1 & -8.1 & -1.3 & -5.7 & -4.1 & -18.5 & -3.4 & -18.8 & -2.1 & -14.3 \\
\hline \multicolumn{13}{|c|}{$\begin{array}{l}\text { Capital-importing de- } \\
\text { veloping countries }^{3}\end{array}$} \\
\hline All banks & -11.6 & -7.9 & -11.7 & -8.6 & -6.1 & -4.9 & -14.8 & -12.6 & -14.6 & -14.2 & -11.3 & -12.9 \\
\hline Nine banks & -6.3 & -6.9 & -7.0 & -8.2 & -3.6 & -4.6 & -7.1 & -9.6 & -7.3 & -10.9 & -5.9 & -9.9 \\
\hline Fifteen banks & -4.6 & -15.5 & -2.8 & -11.2 & -1.2 & -5.6 & -3.5 & -16.5 & -3.9 & -22.4 & -3.3 & -24.5 \\
\hline Others & -0.8 & -2.9 & -1.9 & -7.7 & -1.3 & -5.4 & -4.2 & -19.0 & -3.4 & -19.0 & -2.1 & -14.4 \\
\hline \multicolumn{13}{|l|}{ Africa } \\
\hline All banks & -2.8 & -22.4 & -2.0 & -20.1 & -0.3 & -4.0 & -1.3 & -17.0 & -0.5 & -7.8 & -0.9 & -16.4 \\
\hline Nine banks & -1.6 & -18.3 & -1.4 & -19.4 & -0.1 & -2.5 & -1.0 & -17.4 & -0.3 & -7.0 & -0.7 & -15.9 \\
\hline Fifteen banks & -0.9 & -38.2 & -0.3 & -23.1 & -0.1 & -8.6 & -0.1 & -13.6 & - & 2.7 & -0.2 & -21.5 \\
\hline Others & -0.3 & -23.9 & -0.2 & -20.9 & -0.1 & -10.1 & -0.1 & -18.8 & -0.2 & -32.1 & - & -8.7 \\
\hline \multicolumn{13}{|l|}{ Asia } \\
\hline All banks & -3.4 & -11.9 & -4.9 & -19.3 & -2.2 & -10.7 & -3.2 & -17.6 & -0.6 & -3.8 & -0.6 & -4.1 \\
\hline Nine banks & -2.6 & -13.5 & -2.9 & -17.7 & -1.6 & -11.6 & -2.7 & -22.5 & -0.1 & -1.2 & 0.3 & 2.9 \\
\hline Fifteen banks & -0.9 & -14.9 & -1.1 & -21.4 & -0.9 & -21.3 & - & -0.3 & - & 1.2 & -0.8 & -24.6 \\
\hline Others & 0.1 & 4.3 & -0.8 & -23.9 & 0.3 & 11.7 & -0.5 & -17.0 & -0.5 & -21.9 & - & -2.4 \\
\hline \multicolumn{13}{|l|}{ Indonesia } \\
\hline All banks & -0.6 & -18.8 & -0.6 & -21.6 & -0.6 & -29.4 & -0.4 & -25.6 & -0.1 & -4.2 & 0.2 & 20.5 \\
\hline Nine banks & -0.5 & -16.7 & -0.5 & -22.4 & -0.6 & -30.9 & -0.3 & -26.4 & -0.1 & -7.9 & 0.1 & 16.8 \\
\hline Fifteen banks & -0.2 & -36.9 & - & -14.3 & -0.1 & -27.6 & - & -24.3 & - & -16.8 & - & 6.0 \\
\hline Others & - & 3.0 & - & -24.3 & - & -9.3 & - & -17.4 & - & - & 0.1 & 87.7 \\
\hline \multicolumn{13}{|l|}{ Korea } \\
\hline All banks & -0.8 & -7.9 & -3.2 & -34.6 & -2.1 & -35.8 & - & 0.2 & 0.1 & 3.0 & 0.3 & 8.1 \\
\hline Nine banks & -0.5 & -9.7 & -1.6 & -31.1 & -0.8 & -24.2 & -0.4 & -14.6 & 0.3 & 12.8 & 0.3 & 10.6 \\
\hline Fifteen banks & -0.5 & -17.0 & -0.9 & -41.3 & -0.8 & -59.4 & 0.4 & 71.4 & - & -3.6 & -0.3 & -29.6 \\
\hline Others & 0.2 & 13.3 & -0.7 & -35.8 & -0.5 & -43.9 & - & 1.5 & -0.1 & -21.1 & 0.3 & 59.4 \\
\hline \multicolumn{13}{|l|}{ Philippines } \\
\hline All banks & - & -0.7 & -0.3 & -5.8 & -0.4 & -8.5 & -0.7 & -14.6 & -0.8 & -19.0 & - & -1.1 \\
\hline Nine banks & - & 0.9 & -0.1 & -2.3 & -0.4 & -11.6 & -0.4 & -11.5 & -0.4 & -12.6 & 0.1 & 5.9 \\
\hline Fifteen banks & -0.1 & -6.8 & -0.1 & -13.2 & -0.1 & -9.8 & -0.1 & -16.8 & -0.2 & -34.1 & -0.1 & -20.9 \\
\hline Others & - & 2.1 & -0.1 & -14.9 & 0.1 & 20.6 & -0.2 & -29.9 & -0.1 & -40.3 & -0.1 & -38.5 \\
\hline \multicolumn{13}{|l|}{ Europe } \\
\hline All banks & -0.3 & -4.4 & -0.8 & -12.8 & -0.2 & -4.4 & -0.8 & -15.8 & -0.7 & -17.1 & -0.2 & -6.6 \\
\hline Nine banks & -0.1 & -1.6 & -0.5 & -13.0 & -0.2 & -6.1 & -0.6 & -17.0 & -0.3 & -10.6 & - & -0.8 \\
\hline Fifteen banks & -0.1 & -11.3 & -0.1 & -10.1 & -0.1 & -9.6 & -0.1 & -6.5 & -0.2 & -30.1 & - & -7.0 \\
\hline Others & -0.1 & -7.6 & -0.1 & -15.1 & 0.1 & 10.8 & -0.2 & -20.7 & -0.2 & -28.9 & -0.2 & -38.0 \\
\hline \multicolumn{13}{|l|}{ Middle East } \\
\hline All banks & -0.7 & -18.8 & -0.6 & -20.3 & -0.7 & -29.2 & -0.4 & -20.5 & -0.3 & -22.8 & -0.1 & -8.2 \\
\hline Nine banks & -0.5 & -20.6 & -0.5 & -23.4 & -0.5 & -31.6 & -0.2 & -23.3 & -0.3 & -32.5 & -0.1 & -18.2 \\
\hline Fifteen banks & -0.2 & -24.7 & -0.1 & -17.7 & -0.1 & -29.0 & -0.1 & -13.6 & - & -10.7 & - & 23.4 \\
\hline Others & -0.1 & -7.3 & -0.1 & -12.9 & -0.1 & -22.7 & - & -9.7 & - & -9.5 & - & -9.1 \\
\hline \multicolumn{13}{|l|}{ Western Hemisphere } \\
\hline All banks & -4.5 & -4.7 & -3.5 & -3.9 & -2.7 & -3.0 & -9.1 & -10.7 & -12.6 & -16.5 & -9.6 & -15.2 \\
\hline Nine banks & -1.5 & -2.7 & -1.6 & -3.0 & -1.2 & -2.2 & -2.6 & -5.0 & -6.3 & -12.7 & -5.5 & -12.6 \\
\hline Fifteen banks & -2.5 & -13.0 & -1.1 & -6.8 & -0.1 & -0.4 & -3.1 & -20.0 & -3.8 & -30.4 & -2.3 & -27.1 \\
\hline Others & -0.5 & -2.5 & -0.8 & -3.9 & -1.4 & -7.6 & -3.4 & -19.5 & -2.5 & -17.8 & -1.8 & -15.8 \\
\hline
\end{tabular}




\section{Table A6 (concluded).}

\begin{tabular}{|c|c|c|c|c|c|c|c|c|c|c|c|c|}
\hline & \multicolumn{2}{|c|}{1985} & \multicolumn{2}{|c|}{1986} & \multicolumn{2}{|c|}{1987} & \multicolumn{2}{|c|}{1988} & \multicolumn{2}{|c|}{$1989^{2}$} & \multicolumn{2}{|c|}{$1990^{2}$} \\
\hline & $\begin{array}{l}\text { Billion } \\
\text { U.S. } \\
\text { dollars }\end{array}$ & $\begin{array}{l}\text { Growth } \\
\text { rate }\end{array}$ & $\begin{array}{l}\text { Billion } \\
\text { U.S. } \\
\text { dollars }\end{array}$ & $\begin{array}{l}\text { Growth } \\
\text { rate }\end{array}$ & $\begin{array}{l}\text { Billion } \\
\text { U.S. } \\
\text { dollars }\end{array}$ & $\begin{array}{l}\text { Growth } \\
\text { rate }\end{array}$ & $\begin{array}{l}\text { Billion } \\
\text { U.S. } \\
\text { dollars }\end{array}$ & $\begin{array}{l}\text { Growth } \\
\text { rate }\end{array}$ & $\begin{array}{c}\text { Billion } \\
\text { U.S. } \\
\text { dollars }\end{array}$ & $\begin{array}{l}\text { Growth } \\
\text { rate }\end{array}$ & $\begin{array}{l}\text { Billion } \\
\text { U.S. } \\
\text { dollars }\end{array}$ & $\begin{array}{l}\text { Growth } \\
\text { rate }\end{array}$ \\
\hline \multicolumn{13}{|l|}{ Argentina } \\
\hline All banks & 0.4 & 5.5 & 0.1 & 1.4 & 0.3 & 3.4 & -0.9 & -10.6 & -3.4 & -42.9 & -1.0 & -22.3 \\
\hline Nine banks & 0.8 & 15.1 & 0.1 & 0.9 & 0.4 & 6.2 & -0.3 & -4.5 & -2.6 & -42.6 & -0.7 & -21.2 \\
\hline Fifteen banks & -0.2 & -13.3 & - & 1.4 & - & 1.2 & -0.4 & -24.4 & -0.6 & -45.4 & - & -6.0 \\
\hline Others & -0.1 & -8.6 & - & 4.2 & -0.1 & -10.3 & -0.3 & -28.9 & -0.2 & -40.2 & -0.2 & -62.5 \\
\hline \multicolumn{13}{|l|}{ Brazil } \\
\hline All banks & -1.1 & -4.5 & -0.4 & -1.7 & -1.1 & -5.0 & -1.9 & -8.9 & -3.1 & -16.0 & -4.8 & -29.7 \\
\hline Nine banks & -0.3 & -1.6 & -0.2 & -1.2 & -0.4 & -2.3 & -0.1 & -0.4 & -1.7 & -11.2 & -3.3 & -24.6 \\
\hline Fifteen banks & -0.8 & -16.6 & -0.2 & -4.7 & -0.3 & -7.7 & -0.7 & -21.1 & -1.0 & -37.6 & -0.8 & -45.4 \\
\hline Others & - & -1.2 & - & -0.5 & -0.5 & -14.9 & -1.1 & -39.3 & -0.4 & -24.2 & -0.8 & -61.7 \\
\hline \multicolumn{13}{|l|}{ Mexico } \\
\hline All banks & -1.6 & -6.0 & -1.3 & -5.1 & -0.9 & -3.9 & -4.8 & -21.3 & -1.8 & -10.2 & -0.8 & -5.3 \\
\hline Nine banks & -0.6 & -4.1 & -0.7 & -5.2 & - & - & -1.6 & -11.7 & -0.3 & -2.1 & -0.2 & -2.1 \\
\hline Fifteen banks & -0.6 & -12.0 & -0.1 & -1.1 & -0.3 & -6.8 & -1.7 & -39.4 & -0.8 & -30.5 & - & 0.8 \\
\hline Others & -0.3 & -5.3 & -0.5 & -8.1 & -0.6 & -10.9 & -1.6 & -31.2 & -0.8 & -22.4 & -0.6 & -23.2 \\
\hline \multicolumn{13}{|l|}{ Venezuela } \\
\hline All banks & -0.7 & -6.7 & -1.0 & -9.7 & -0.8 & -8.7 & -0.3 & -3.8 & -0.9 & -10.7 & -0.7 & -9.9 \\
\hline Nine banks & -0.3 & -4.1 & -0.6 & -8.7 & -0.7 & -10.5 & -0.2 & -3.0 & 0.1 & 1.4 & -0.1 & -1.3 \\
\hline Fifteen banks & -0.3 & -15.9 & -0.2 & -9.2 & - & 1.2 & -0.2 & -15.2 & -0.7 & -50.5 & -0.3 & -49.5 \\
\hline Others & -0.1 & -6.8 & -0.2 & -15.9 & -0.1 & -11.9 & 0.1 & 10.7 & -0.3 & -25.7 & -0.3 & -40.5 \\
\hline $\begin{array}{l}\text { Source: Federal Fin } \\
\text { 'Data are based on } \\
{ }^{2} \text { Data for } 1989-90 \\
\text { 'Excludes offshore }\end{array}$ & w & $\begin{array}{l}\text { of be } \\
\text { najor }\end{array}$ & cou & . & $x p$ & 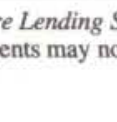 & $\begin{array}{l}\text { irvey. } \\
\text { add. }\end{array}$ & & & & & \\
\hline
\end{tabular}


Table A7. U.S. Banks: Developing Country Claims Relative to Capital, 1984-90

\begin{tabular}{|c|c|c|c|c|c|c|c|}
\hline & 1984 & 1985 & 1986 & 1987 & 1988 & 1989 & 1990 \\
\hline & \multicolumn{7}{|c|}{ (In billions of U.S. dollars) } \\
\hline External claims on developing countries ${ }^{1}$ & 140.8 & 128.8 & 118.6 & 108.8 & 93.2 & 78.8 & 65.9 \\
\hline Total assets & $1,413.0$ & $1,529.0$ & $1,613.0$ & $1,633.0$ & $1,670.3$ & $1,770.0$ & $1,764.1$ \\
\hline Capital & 92.2 & 105.4 & 116.1 & 129.2 & 135.6 & 145.2 & 152.9 \\
\hline \multicolumn{8}{|l|}{ Memorandum items } \\
\hline Capital to total assets & 6.5 & 6.9 & 7.2 & 7.9 & 8.1 & 8.2 & 8.7 \\
\hline \multicolumn{8}{|l|}{ External claims on developing } \\
\hline countries to total assets & 10.0 & 8.4 & 7.4 & 6.7 & 5.6 & 4.5 & 3.7 \\
\hline $\begin{array}{l}\text { Capital to external claims on } \\
\text { developing countries }\end{array}$ & 65.5 & 81.8 & 97.9 & 118.8 & 145.5 & 184.3 & 232.0 \\
\hline
\end{tabular}

Sources: Federal Financial Institutions Examination Council, Country Exposure Lending Survey; and International Monetary Fund, International Financial Statistics.

'Data are based on exposure, that is, claims are adjusted for guarantees and other risk transfers.

Table A8. Terms of Long-Term Bank Credit Commitments, 1985-April $1991^{1}$

\begin{tabular}{|c|c|c|c|c|c|c|c|}
\hline & 1985 & 1986 & 1987 & 1988 & 1989 & 1990 & $\begin{array}{c}\text { Jan.-Apr. } \\
1991\end{array}$ \\
\hline Average maturity (in years) & 7.8 & 6.7 & 8.3 & 5.7 & 6.2 & 6.5 & 5.3 \\
\hline OECD countries & 7.4 & 6.3 & 7.5 & 5.1 & 5.8 & 5.8 & 4.9 \\
\hline Eastern Europe & 7.4 & 7.8 & 8.1 & 8.4 & 8.3 & 11.9 & - \\
\hline Developing countries & 8.4 & 8.2 & 10.7 & 9.0 & 7.3 & 8.6 & 8.8 \\
\hline Other & 7.3 & 6.8 & 6.1 & 6.5 & 8.8 & 6.6 & 2.0 \\
\hline Average spread (basis points) & 62 & 41 & 42 & 35 & 56 & 52 & 87 \\
\hline OECD countries & 47 & 37 & 34 & 31 & 54 & 51 & 83 \\
\hline Eastern Europe & 55 & 26 & 24 & 30 & 49 & 50 & - \\
\hline Developing countries & 92 & 61 & 68 & 65 & 68 & 60 & 100 \\
\hline Other & 56 & 33 & 48 & 42 & 32 & 47 & 188 \\
\hline \multicolumn{8}{|l|}{ Memorandum items (in percent) } \\
\hline $\begin{array}{l}\text { Six-month Eurodollar interbank rate (av- } \\
\text { erage) }\end{array}$ & 8.64 & 6.85 & 7.30 & 8.13 & 9.27 & 8.35 & 6.38 \\
\hline U.S. prime rate (average) & 9.93 & 8.35 & 8.21 & 9.32 & 10.92 & 10.01 & 9.00 \\
\hline
\end{tabular}


Table A9. Average Spreads on Bank Credit Commitments

for Developing Countries, 1984-90

(In basis points over London interbank offered rate)

\begin{tabular}{|c|c|c|c|c|c|c|c|}
\hline & 1984 & 1985 & 1986 & 1987 & 1988 & 19891 & $1990^{1}$ \\
\hline Spontaneous commitments ${ }^{2}$ & 72 & 64 & 61 & 56 & 57 & 68 & 60 \\
\hline \multicolumn{8}{|l|}{ Concerted commitments ${ }^{3}$} \\
\hline All & 185 & 179 & 84 & 89 & 83 & 81 & 95 \\
\hline Three largest debtors & 186 & $\ldots$ & 81 & 88 & 81 & 81 & $\ldots$ \\
\hline Others & 174 & 179 & 140 & 100 & 108 & 81 & 95 \\
\hline \multicolumn{8}{|l|}{ Restructuring of existing debt ${ }^{3}$} \\
\hline All & 131 & 138 & 95 & 80 & 83 & 81 & 82 \\
\hline Three largest debtors ${ }^{4}$ & 128 & . & 85 & 81 & 81 & 81 & $\ldots$ \\
\hline Others & 136 & 138 & 140 & 80 & 88 & 81 & 82 \\
\hline \multicolumn{8}{|l|}{ Memorandum items } \\
\hline \multicolumn{8}{|l|}{ Difference between spreads } \\
\hline Concerted/spontaneous & 113 & 115 & 23 & 33 & 26 & 13 & 35 \\
\hline Restructuring/spontaneous & 59 & 74 & 34 & 24 & 26 & 13 & 22 \\
\hline Concerted/restructuring & 54 & 41 & -11 & 9 & - & - & 13 \\
\hline \multicolumn{8}{|l|}{ Largest/others } \\
\hline Concerted & 12 & $\ldots$ & -59 & -12 & -27 & - & $\ldots$ \\
\hline Restructurings & -8 & $\ldots$ & -55 & 1 & -7 & - & $\ldots$ \\
\hline
\end{tabular}

Sources: Organization for Economic Cooperation and Development, Financial Market Trends; and IMF staff estimates.

'Excludes restructurings of claims involving debt and debt-service reduction.

${ }^{2}$ Weighted average of nonconcerted bank commitments to "Developing Countries" as defined by the OECD.

${ }^{3}$ Based on term sheets agreed in principle.

${ }^{4}$ Argentina, Brazil, and Mexico. 
Table A10. Selected Developing Countries: Terms on Syndicated Bank Credits, 1989-May 1991 ${ }^{1}$

\begin{tabular}{|c|c|c|c|c|c|c|}
\hline & \multicolumn{2}{|c|}{1989} & \multicolumn{2}{|c|}{1990} & \multicolumn{2}{|c|}{ Jan.-May 1991} \\
\hline & Maturity & Spread & Maturity & Spread & Maturity & Spread \\
\hline & (In years) & $\begin{array}{l}\text { (In basis } \\
\text { points) }\end{array}$ & (In years) & $\begin{array}{l}\text { (In basis } \\
\text { points) }\end{array}$ & (In years) & $\begin{array}{l}\text { (In basis } \\
\text { points) }\end{array}$ \\
\hline Bahrain & 10.5 & 51 & 7.2 & 38 & 3.0 & 65 \\
\hline Bulgaria & 7.0 & 40 & - & - & - & - \\
\hline China & 9.3 & 63 & 9.8 & 61 & 11.3 & 142 \\
\hline Colombia & 11.8 & 87 & - & - & 5.0 & 150 \\
\hline Hong Kong & 4.6 & 31 & 4.4 & 62 & 8.5 & 72 \\
\hline Hungary & 8.8 & 53 & 8.0 & 82 & - & - \\
\hline India & 10.4 & 30 & 8.4 & 30 & - & - \\
\hline Indonesia & 7.0 & 95 & 9.3 & 78 & 5.8 & 99 \\
\hline Korea & 7.1 & 38 & 10.3 & 48 & 7.4 & 54 \\
\hline Malaysia & 5.8 & 22 & 13.3 & 58 & - & - \\
\hline Mexico & 3.2 & 300 & 7.0 & 175 & - & - \\
\hline Pakistan & 2.2 & 92 & - & - & 1.0 & 90 \\
\hline Singapore & 4.2 & 73 & 10.3 & 26 & 3.0 & 137 \\
\hline Thailand & 7.0 & 51 & 7.8 & 56 & 7.7 & 89 \\
\hline $\begin{array}{l}\text { Average for Eastern European countries } \\
\text { Of which: }\end{array}$ & 8.3 & 49 & 11.9 & 50 & - & - \\
\hline U.S.S.R. & 6.2 & 49 & 12.0 & 50 & - & - \\
\hline
\end{tabular}


Table A11. Amounts of Medium- and Long-Term

Bank Debt Restructured, 1985-June 1991 ${ }^{1}$

(In millions of U.S. dollars; by year of agreement in principle)

\begin{tabular}{|c|c|c|c|c|c|c|c|}
\hline & 1985 & 1986 & 1987 & 1988 & 1989 & 1990 & $\begin{array}{c}1991 \\
\text { First Half }\end{array}$ \\
\hline Argentina & - & - & $29,500^{2}$ & - & - & - & - \\
\hline Bolivia & - & - & - & - & - & - & - \\
\hline Brazil & - & $6,671^{3}$ & - & $61,000^{2}$ & - & - & - \\
\hline Chile & 6,007 & - & $5,902^{2}$ & - & - & $1,800^{4}$ & - \\
\hline Congo & - & 217 & - & - & - & - & - \\
\hline Costa Rica & 440 & - & - & - & $1,825^{5}$ & - & - \\
\hline Côte d'Ivoire & - & $691^{2}$ & - & $2,211^{2}$ & - & - & - \\
\hline Dominican Republic & $787^{2}$ & - & - & - & - & - & - \\
\hline Ecuador & - & - & - & $4,683^{2}$ & - & - & - \\
\hline Gabon & - & - & 39 & - & - & - & - \\
\hline Gambia, The & - & - & 19 & - & - & - & - \\
\hline Guinea & - & - & 43 & - & - & - & - \\
\hline Guyana & $(47)^{4}$ & $(57)^{4}$ & - & - & - & - & - \\
\hline Honduras & - & - & $248^{2}$ & - & $132^{2}$ & - & - \\
\hline Jamaica & 195 & - & $285^{2}$ & - & - & 332 & - \\
\hline Jordan & - & - & - & - & $580^{2}$ & - & - \\
\hline Madagascar & $\ldots 7^{7}$ & - & $\ldots 7$ & - & - & 21 & - \\
\hline Malawi & - & - & - & $35^{2}$ & - & - & - \\
\hline Mexico & $(950)^{8}$ & $43,700^{2}$ & - & $3,671^{5}$ & 48,0895 & - & - \\
\hline Morocco & 538 & 2,174 & - & - & - & 3,150 & - \\
\hline Mozambique & - & - & $253^{2}$ & - & - & - & - \\
\hline Nicaragua & - & - & - & - & - & - & - \\
\hline Niger & - & 52 & - & - & - & - & 110 \\
\hline Nigeria & - & 4,250 & - & $5,824^{2}$ & - & - & - \\
\hline Panama & 579 & - & - & - & - & - & - \\
\hline Peru & - & - & - & - & - & - & - \\
\hline Philippines & - & - & $9,010^{2}$ & - & 781 & - & - \\
\hline Poland & - & 1,970 & $8,441^{2}$ & - & $(351)^{6}$ & - & - \\
\hline Romania & - & 800 & - & - & - & - & - \\
\hline Senegal & 20 & - & - & - & - & 37 & - \\
\hline Sierra Leone & - & - & - & - & - & - & - \\
\hline South Africa & - & $(9,800)^{6}$ & $10,900^{2}$ & - & - & - & - \\
\hline Sudan & 920 & - & - & - & - & - & - \\
\hline Togo & - & - & - & $49^{2}$ & - & - & - \\
\hline Trinidad and Tobago & - & - & - & $470^{2}$ & - & - & - \\
\hline Uruguay & $1,958^{2}$ & - & $1,770^{2}$ & - & - & $1,604^{9}$ & - \\
\hline Venezuela & - & - & $20,338^{2}$ & - & - & $19,786^{9}$ & - \\
\hline Yugoslavia & $4,012^{2}$ & - & - & $6,895^{2}$ & - & - & - \\
\hline Zaïre & $(61)^{6}$ & $(65)^{6}$ & $(61)^{6}$ & - & $(61)^{6}$ & - & - \\
\hline Zambia & - & - & - & - & - & - & - \\
\hline Total ${ }^{10}$ & 15,456 & 60,525 & 91,431 & 80,155 & 51,552 & 26,730 & 110 \\
\hline \multicolumn{8}{|c|}{ 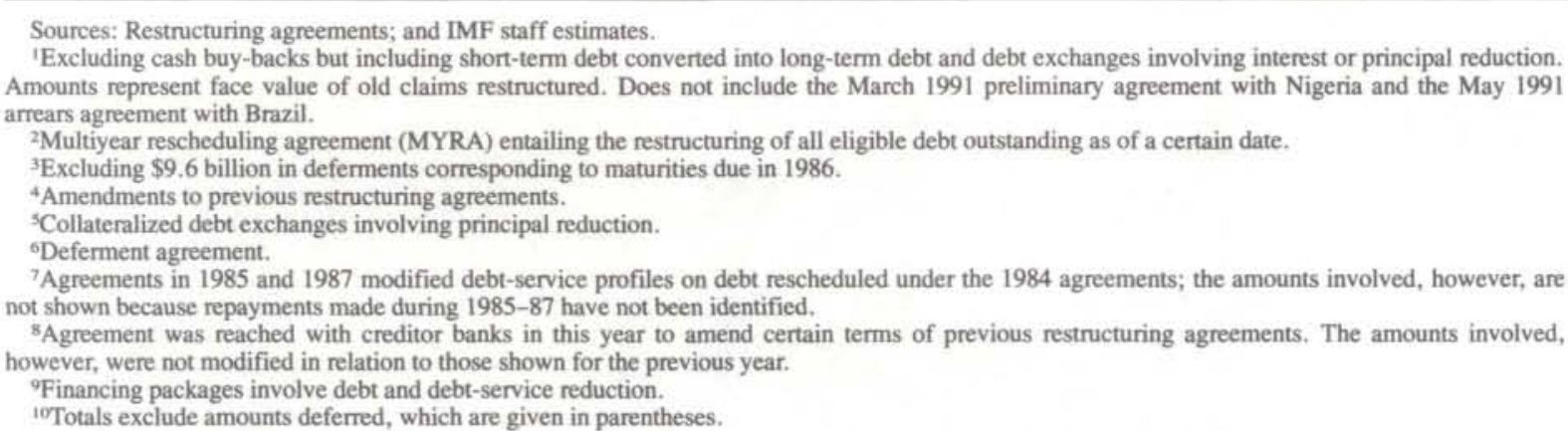 } \\
\hline
\end{tabular}



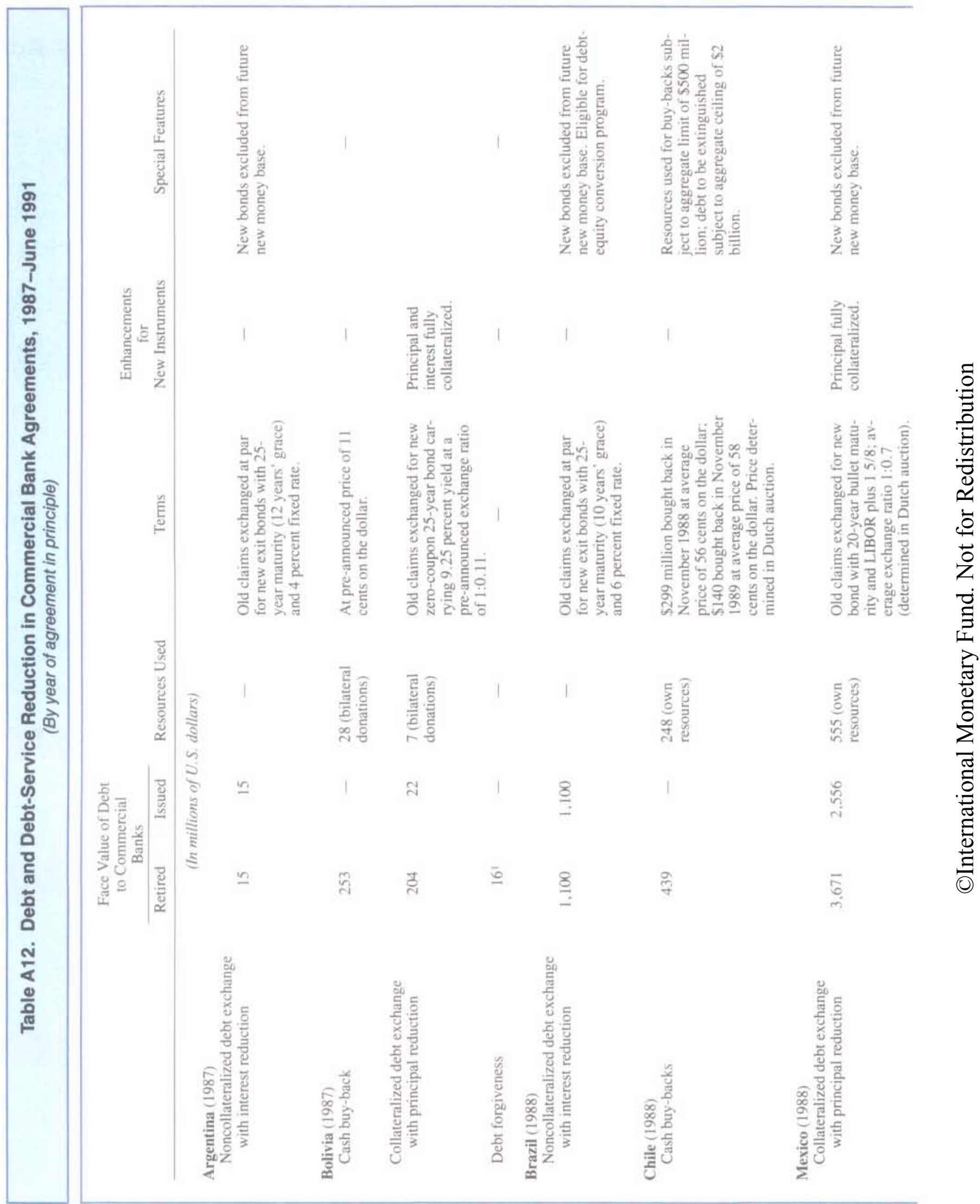

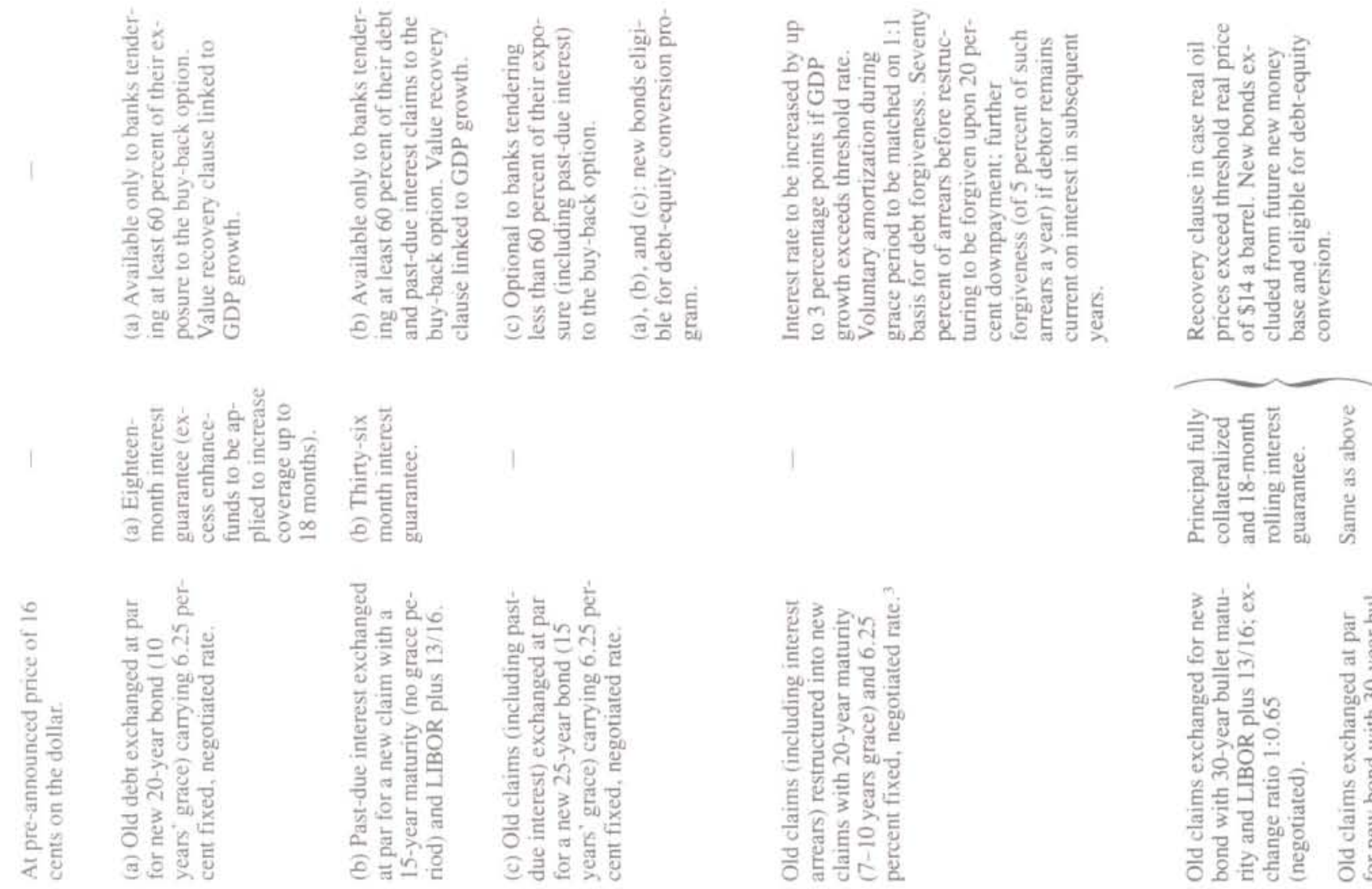


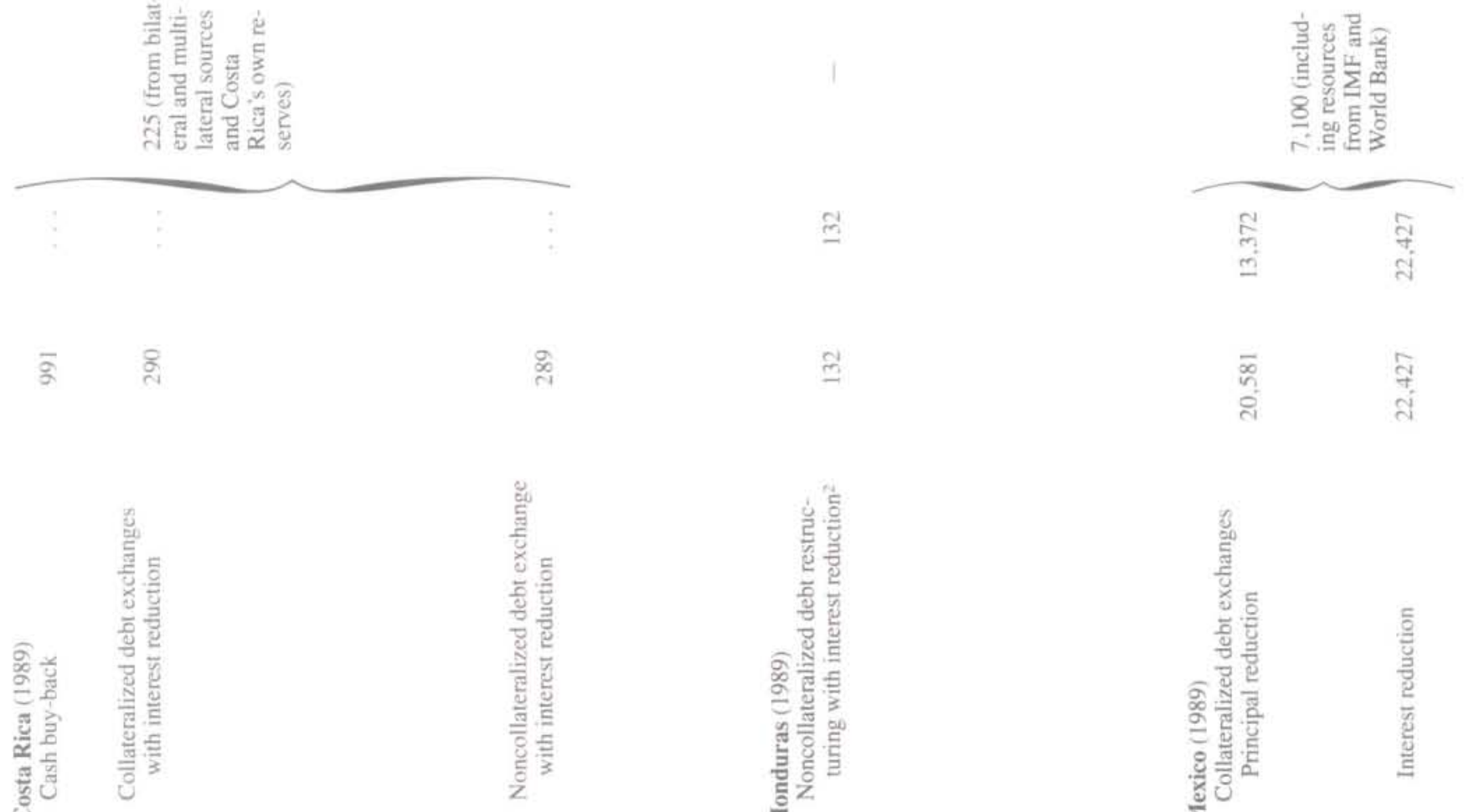

$\bar{\infty}$
ก
ก
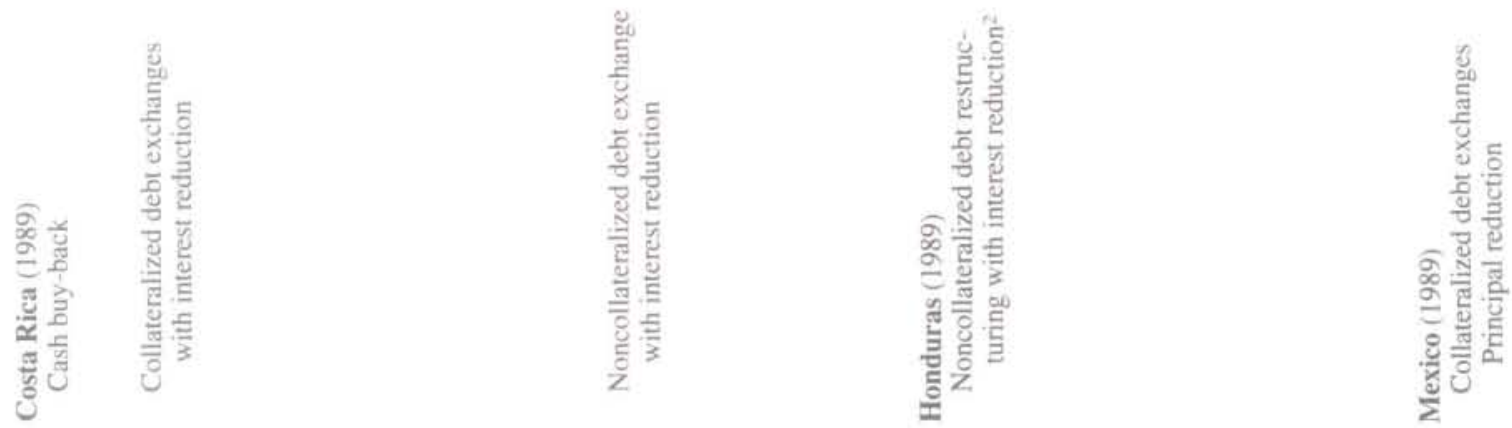


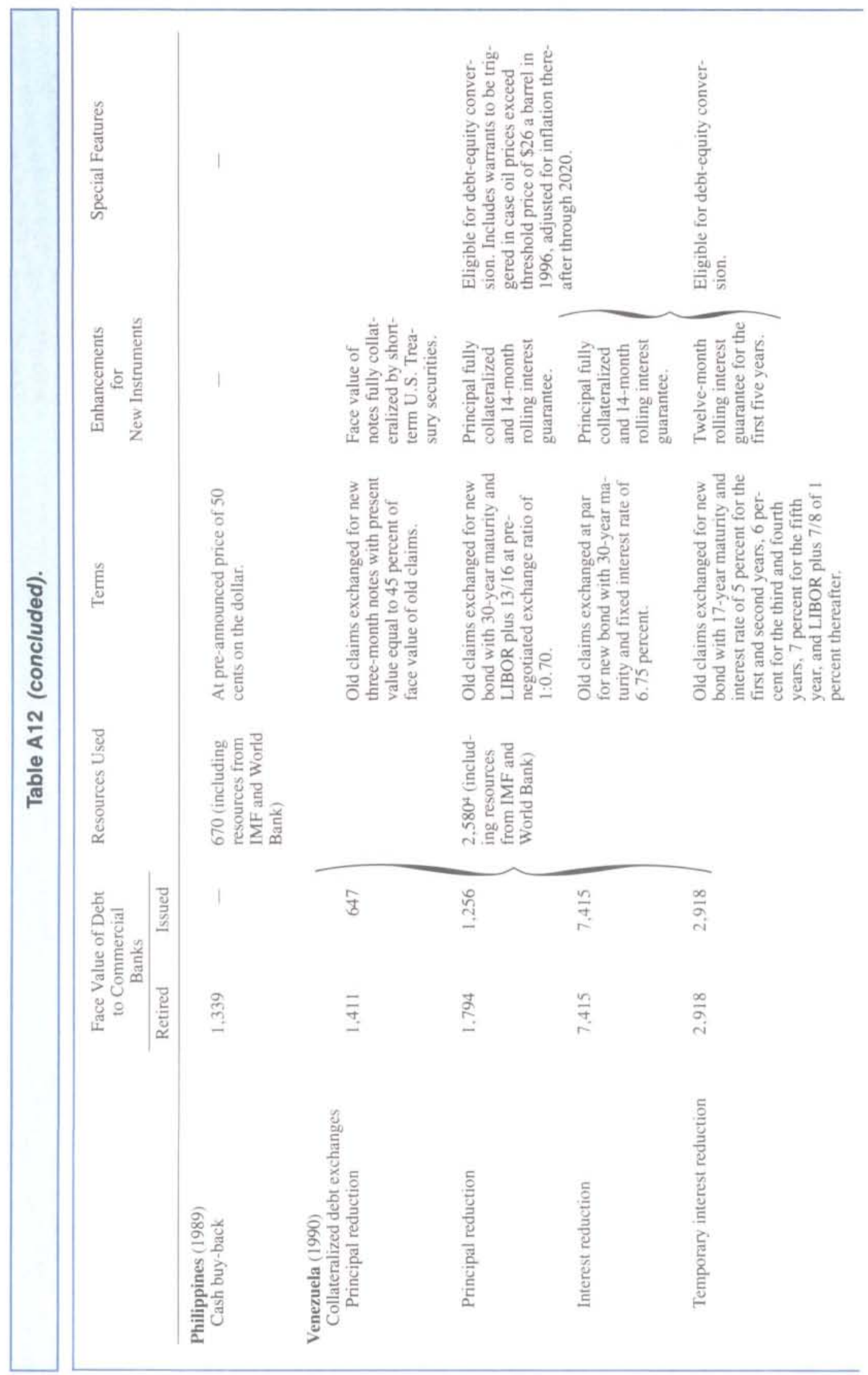



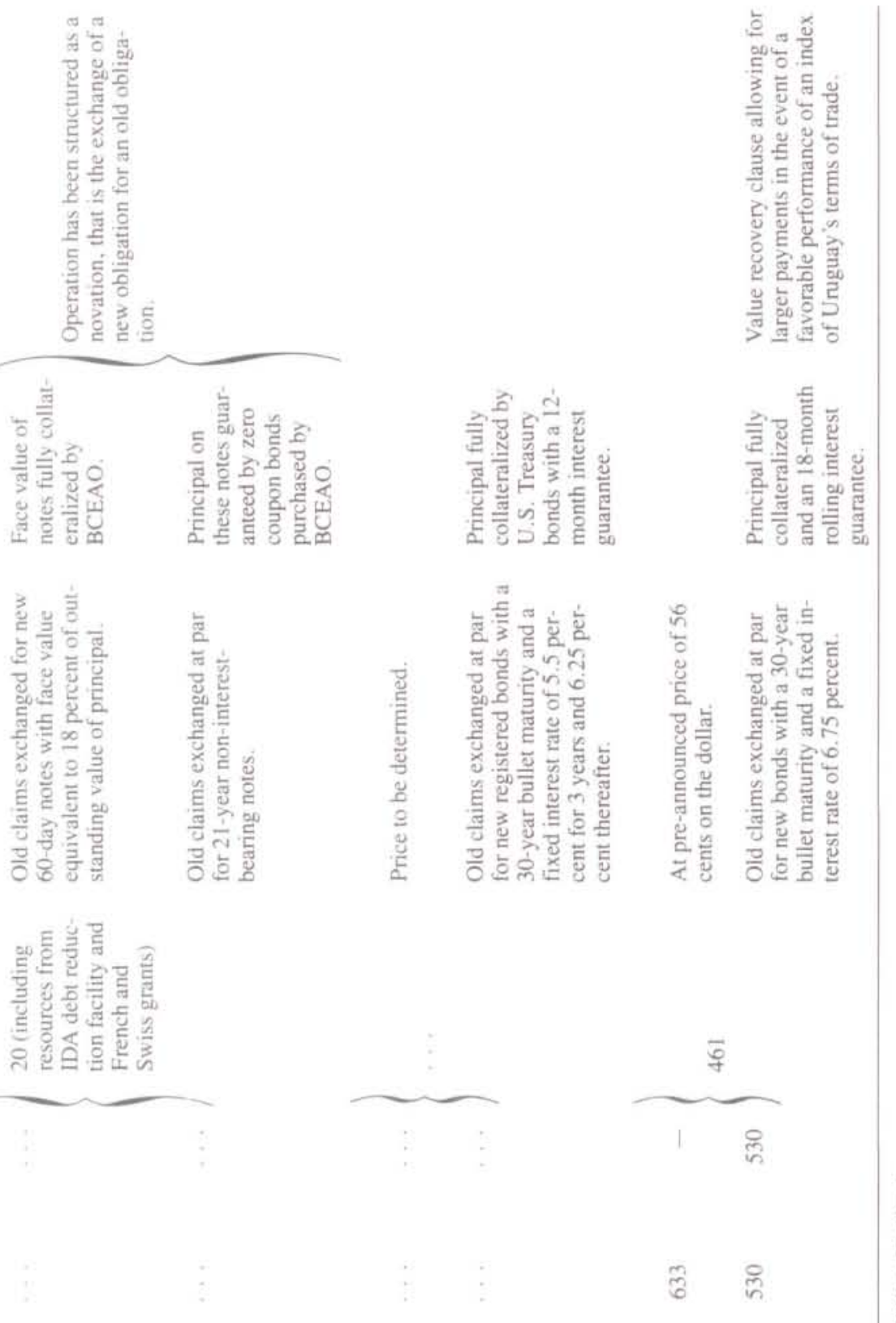

ถู ह

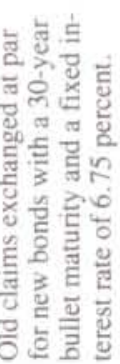

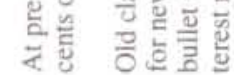
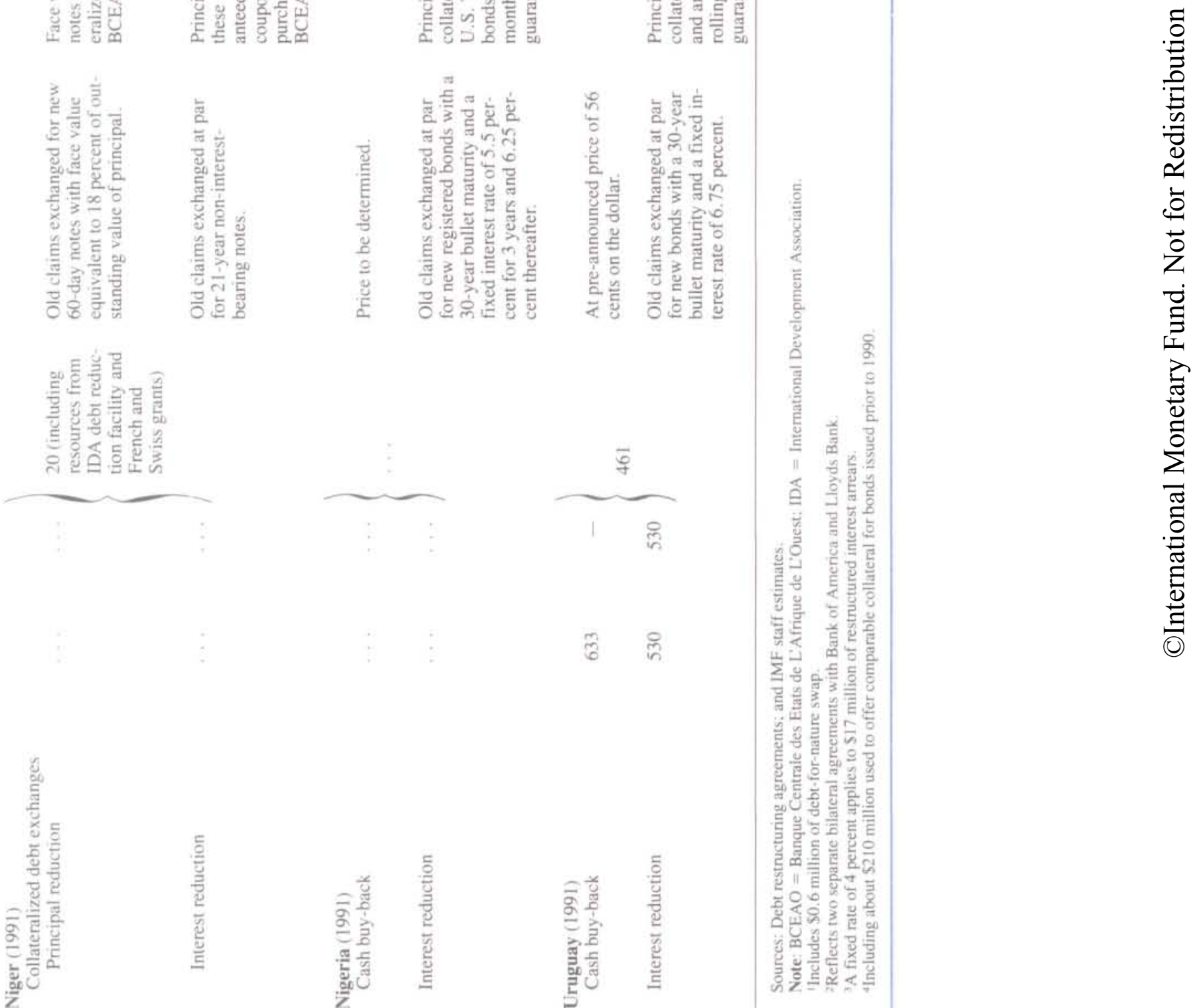


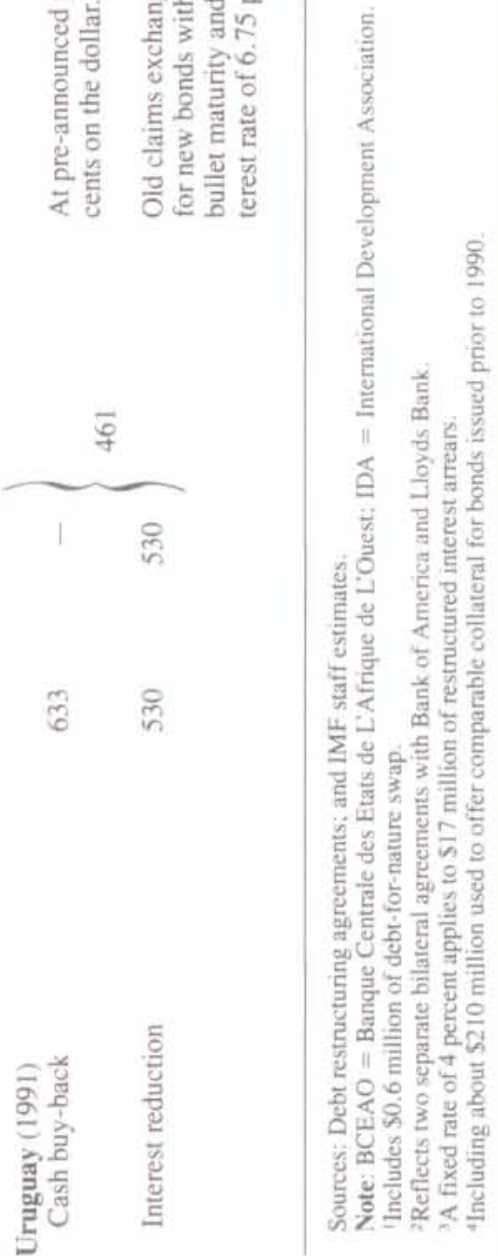
Table A13. Terms of Selected Bank Debt Restructurings and Financial Packages, 1984-June 1991 ${ }^{1}$

\begin{tabular}{|c|c|c|c|c|c|c|}
\hline Country & $\begin{array}{l}\text { Year of } \\
\text { Agreement }\end{array}$ & $\begin{array}{l}\text { Type of } \\
\text { Transaction }\end{array}$ & $\begin{array}{l}\text { Grace } \\
\text { Period }\end{array}$ & Maturity & Interest Rate & Fees \\
\hline & & & & ars) & $\begin{array}{c}\text { (In percent spread } \\
\text { over LIBOR/U.S. Prime) }\end{array}$ & $\begin{array}{c}(\text { In } \\
\text { percent })\end{array}$ \\
\hline \multirow[t]{6}{*}{ Argentina } & 1984 & Restructuring & 3 & 10 to 12 & $1^{3 / 8}$ & - \\
\hline & & New financing & 3 & 10 & $1^{5 / 8}-1^{1 / 4}$ & $5 / 8$ \\
\hline & 1987 & New financing & 5 & 12 & $7 / 8$ & $3 / 8^{2}$ \\
\hline & & New financing ${ }^{3}$ & - & 4 & $7 / 8$ & $3 / 8^{2}$ \\
\hline & & Restructuring 4,5 & 7 & 19 & $13 / 16$ & - \\
\hline & & Restructuring 4.5 & 5 & 12 & $13 / 16$ & - \\
\hline \multirow{6}{*}{ Brazil } & 1984 & Restructuring & 5 & 9 & $2-1^{3 / 4}$ & 1 \\
\hline & & New financing & 5 & 9 & $2-1^{3 / 4}$ & 1 \\
\hline & 1986 & Restructuring & 5 & 7 & $1^{1 / 8}$ & - \\
\hline & 1988 & Restructurings & 7 & 19 & $13 / 16$ & - \\
\hline & & New financing 6 & 5 & 12 & $13 / 16$ & $3 / 8^{2}$ \\
\hline & & New financing ${ }^{3}$ & 9 & 9 & $13 / 16$ & $3 / 8^{2}$ \\
\hline \multirow[t]{8}{*}{ Chile } & 1984 & New financing & 5 & 9 & $13 / 4-11 / 2$ & $5 / 8$ \\
\hline & 1985 & Restructuring & 6 & 12 & $13 / 8$ & $1 / 8$ \\
\hline & & New financing & 5 & 10 & $1^{5 / 8}-1^{1 / 4}$ & $1 / 2$ \\
\hline & 1987 & Restructuring 4,5 & 3 & 5 & $11 / 8$ & - \\
\hline & & Restructurings & 5 & $15^{1 / 2}$ & 1 & - \\
\hline & 1988 & Restructuring 4,5 & 5 & 15 & $13 / 16$ & - \\
\hline & & Restructuring 3.4 & 3 & 5 & $7 / 8$ & - \\
\hline & 1990 & Restructuring & 4 & 8 to 12 & Original rates & - \\
\hline \multirow[t]{6}{*}{ Côte d'Ivoire } & 1984 & Restructuring & 2 & 7 & $1^{7 / 8}-1^{5 / 8}$ & $1 \frac{1}{4}$ \\
\hline & & Restructuring & 3 & 8 & $17 / 8-1^{5 / 8}$ & $11 / 4$ \\
\hline & & New financing & 3 & 7 & $17 / 8-15 / 8$ & $1 \frac{1}{4}$ \\
\hline & 1986 & Restructuring 5 & 3 & 9 & $1^{5 / 8}-1^{3 / 8}$ & - \\
\hline & 1988 & Restructurings & 5 & $141 / 2$ & $11 / 4$ & $1 / 2^{2}$ \\
\hline & & New financing & 4 & 8 & $1 \frac{1}{2}$ & $3 / 4^{2}$ \\
\hline Dominican Republic & 1985 & Restructuring 5 & 3 & 13 & $13 / 8$ & - \\
\hline \multirow[t]{5}{*}{ Ecuador } & 1985 & Restructuring 5 & 3 & 12 & $1^{3 / 8}$ & - \\
\hline & & New financing & 2 & 10 & $15 / 8-11 / 4$ & - \\
\hline & 1987 & Restructuring? & 3 & 10 & 1 & \\
\hline & & Restructuring ${ }^{8}$ & 7 & 19 & $15 / 16$ & \\
\hline & & New financing & 2 & 8 & 1 & $1 / 8-1 / 2^{2}$ \\
\hline \multirow[t]{4}{*}{ Jamaica } & 1987 & Rescheduling & $1^{1 / 2}$ & $8^{1 / 2}$ & $11 / 4$ & - \\
\hline & & Rescheduling & 9 & $12^{1 / 2}$ & $11 / 4$ & - \\
\hline & 1990 & Refinancing & - & $10^{1 / 2}$ & $13 / 16$ & - \\
\hline & & Refinancing & $7^{1 / 2}$ & $14^{1 / 2}$ & $13 / 16$ & - \\
\hline \multirow[t]{10}{*}{ Mexico } & 1984 & New financing & $51 / 2$ & 10 & $11 / 2-11 / 8$ & $5 / 8$ \\
\hline & & Restructuring 5 & 0 to 1 & 14 & $7 / 8$ in $1985-86$ & - \\
\hline & & & & & $1 \frac{1}{8}$ in $1987-91$ & - \\
\hline & & & & & $1^{1 / 4}$ in $1992-98$ & - \\
\hline & 1986 & Restructuring 5 & 7 & 20 & $13 / 16$ & - \\
\hline & & New financing & 5 & 12 & $13 / 16$ & - \\
\hline & & New financing ${ }^{9}$ & 7 & 12 & $13 / 16$ & - \\
\hline & & New financing ${ }^{10}$ & 4 & 8 & $13 / 16$ & - \\
\hline & 1989 & New financing & 7 & 15 & $13 / 16$ & - \\
\hline & & Restructuring & 7 & 15 & $13 / 16$ & - \\
\hline
\end{tabular}


Table A13 (concluded).

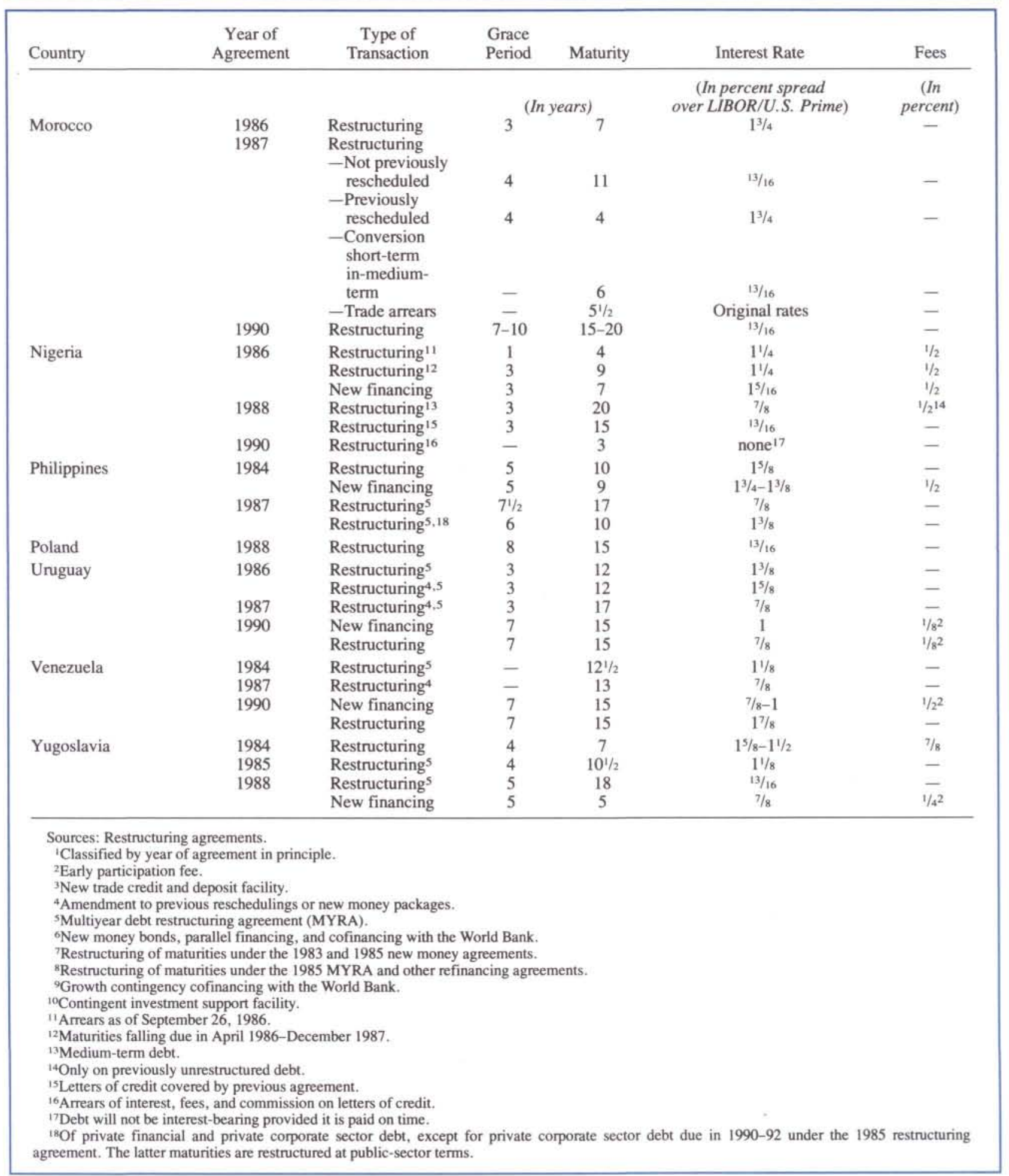


Table A14. Terms and Conditions of Bank Debt Restructurings and Financial Packages, 1987-June 1991'

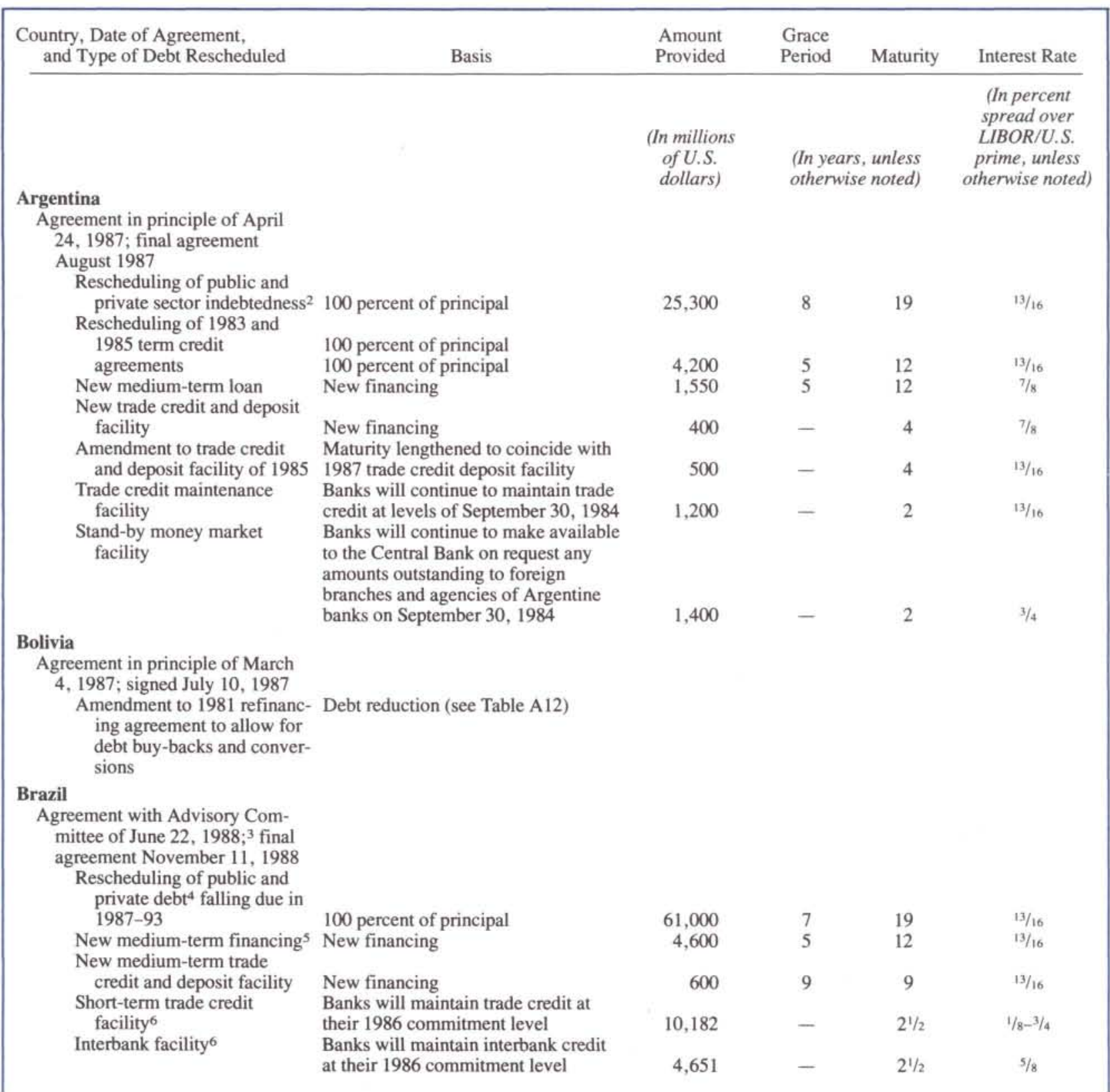




\section{Table A14 (continued).}

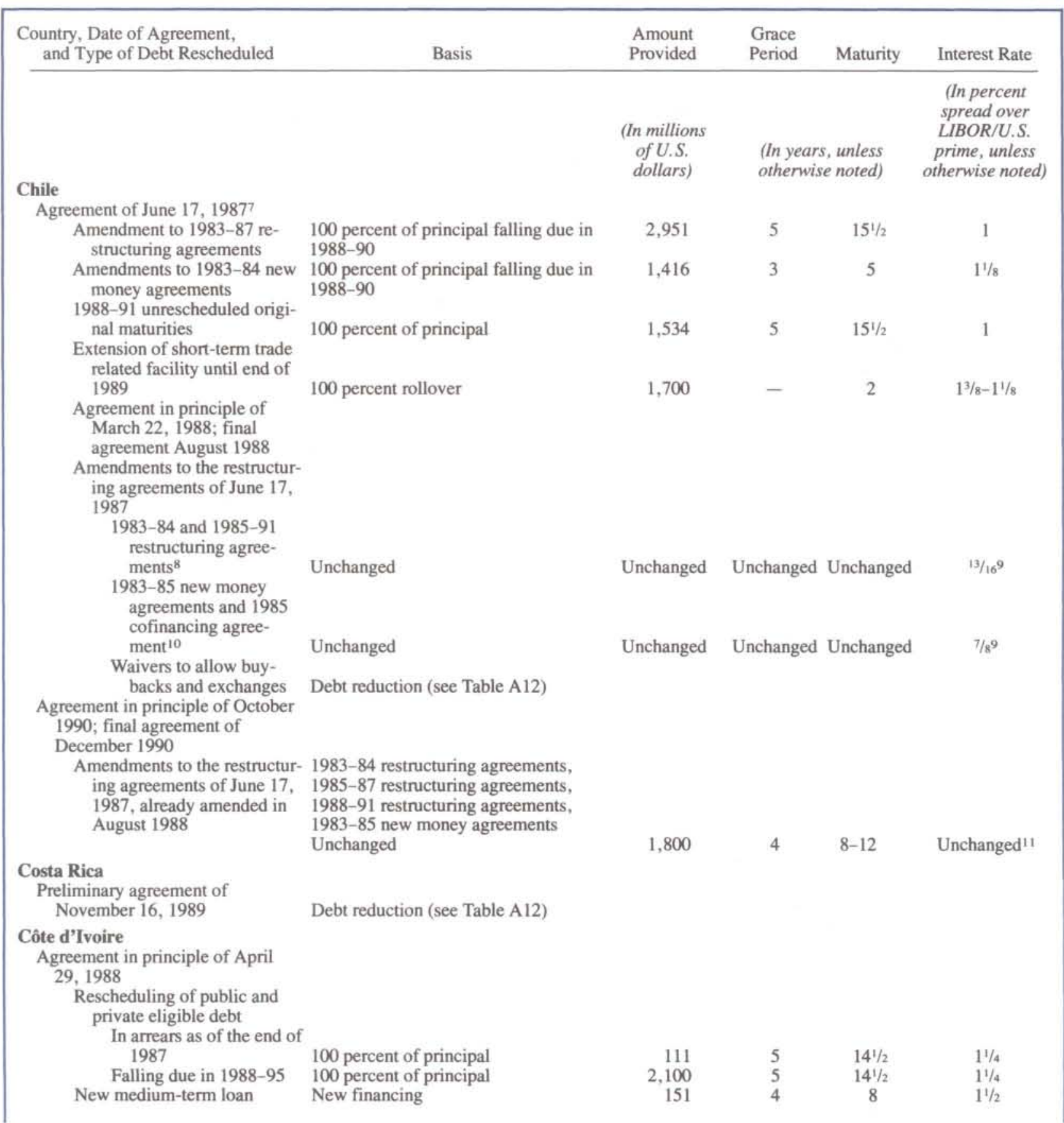




\section{Table A14 (continued).}

\begin{tabular}{|c|c|c|c|c|c|}
\hline $\begin{array}{l}\text { Country, Date of Agreement, } \\
\text { and Type of Debt Rescheduled }\end{array}$ & Basis & $\begin{array}{l}\text { Amount } \\
\text { Provided }\end{array}$ & $\begin{array}{l}\text { Grace } \\
\text { Period }\end{array}$ & Maturity & Interest Rate \\
\hline & & $\begin{array}{l}\text { (In millions } \\
\text { of U.S. } \\
\text { dollars) }\end{array}$ & $\begin{array}{l}\text { (In yec } \\
\text { othern }\end{array}$ & , unless & $\begin{array}{l}\text { (In percent } \\
\text { spread over } \\
\text { LIBOR/U.S. } \\
\text { prime, unless } \\
\text { otherwise noted) }\end{array}$ \\
\hline \multicolumn{6}{|l|}{ Ecuador } \\
\hline \multicolumn{6}{|l|}{$\begin{array}{l}\text { Agreement in principle of } \\
\text { November } 25,1987\end{array}$} \\
\hline $\begin{array}{l}\text { Rescheduling of } 1983 \text { and } \\
1985 \text { new money agree- } \\
\text { ments }\end{array}$ & 100 percent of principal & 631 & 3 & 10 & 1 \\
\hline \multicolumn{6}{|l|}{$\begin{array}{l}\text { Rescheduling of maturities } \\
\text { under } 1985 \text { MYRA and }\end{array}$} \\
\hline New medium-term loan & New financing & 350 & 2 & 8 & 1 \\
\hline \multicolumn{6}{|l|}{ Gabon } \\
\hline $\begin{array}{l}\text { Agreement in principle of June 4, } \\
\text { 1987; final agreement December } \\
\text { 1987 } \\
\text { Rescheduling of principal due } \\
\text { September 21, 1986- } \\
\text { December 31, 1988 }\end{array}$ & 100 percent of principal & 39 & 4 & 9 & $1^{3 / 8}$ \\
\hline $\begin{array}{l}\text { Gambia, The } \\
\text { Agreement in principle of May } 27, \\
\text { 1987; final agreement February } \\
\text { 15, } 1988 \\
\text { Rescheduling of public debt } \\
\text { outstanding as of December }\end{array}$ & & & & & \\
\hline 18,1986 & 100 percent of principal & 19 & $31 / 2$ & 8 & $1 \frac{1 / 4}{4}$ \\
\hline $\begin{array}{l}\text { Guinea } \\
\text { Agreement in principle of Novem- } \\
\text { ber 1987; final agreement April } \\
\text { 20, } 1988 \\
\text { Restructuring of short- and } \\
\text { medium-term debt } \\
\text { outstanding }\end{array}$ & 70 percent of principal & 43 & $1 / 2$ & 3 & $1^{3 / 4}$ \\
\hline \multicolumn{6}{|l|}{$\begin{array}{l}\text { Agreement in principle of June 26, } \\
1987\end{array}$} \\
\hline $\begin{array}{l}\text { Restructuring of principal and } \\
\text { interest in arrears } \\
\text { Restructuring of maturities }\end{array}$ & $\begin{array}{l}100 \text { percent of arrears as of the end of } \\
\text { March } 1987\end{array}$ & 219 & 6 & 8 & $11 / 8$ \\
\hline \multicolumn{6}{|l|}{$\begin{array}{l}\text { Bilateral concessional re- } \\
\text { scheduling of debt to } \\
\text { Lloyds Bank }\end{array}$} \\
\hline $\begin{array}{l}\text { Principal outstanding at } \\
\text { end-October } 1989 \\
\text { Interest arrears at end- }\end{array}$ & 100 percent & $46^{12}$ & 7 & 20 & $\begin{array}{l}6.25 \text { percent } \\
\text { fixed rate }{ }^{13} \\
6.25 \text { percent }\end{array}$ \\
\hline $\begin{array}{l}\text { October } 1989 \\
\text { Bilateral concessional re- } \\
\text { scheduling of debt to Bank } \\
\text { of America }\end{array}$ & 100 percent & $22^{12,14}$ & 7. & 20 & fixed rate ${ }^{13}$ \\
\hline $\begin{array}{l}\text { Principal outstanding } \\
\text { Interest arrears as of end- }\end{array}$ & 100 percent & 4712 & 10 & 20 & $\begin{array}{l}6.5 \text { percent } \\
4 \text { percent fixed }\end{array}$ \\
\hline October 1989 & 100 percent & $17^{14}$ & $2 / 3$ & 20 & rate \\
\hline
\end{tabular}


Table A14 (continued).




Table A14 (continued).

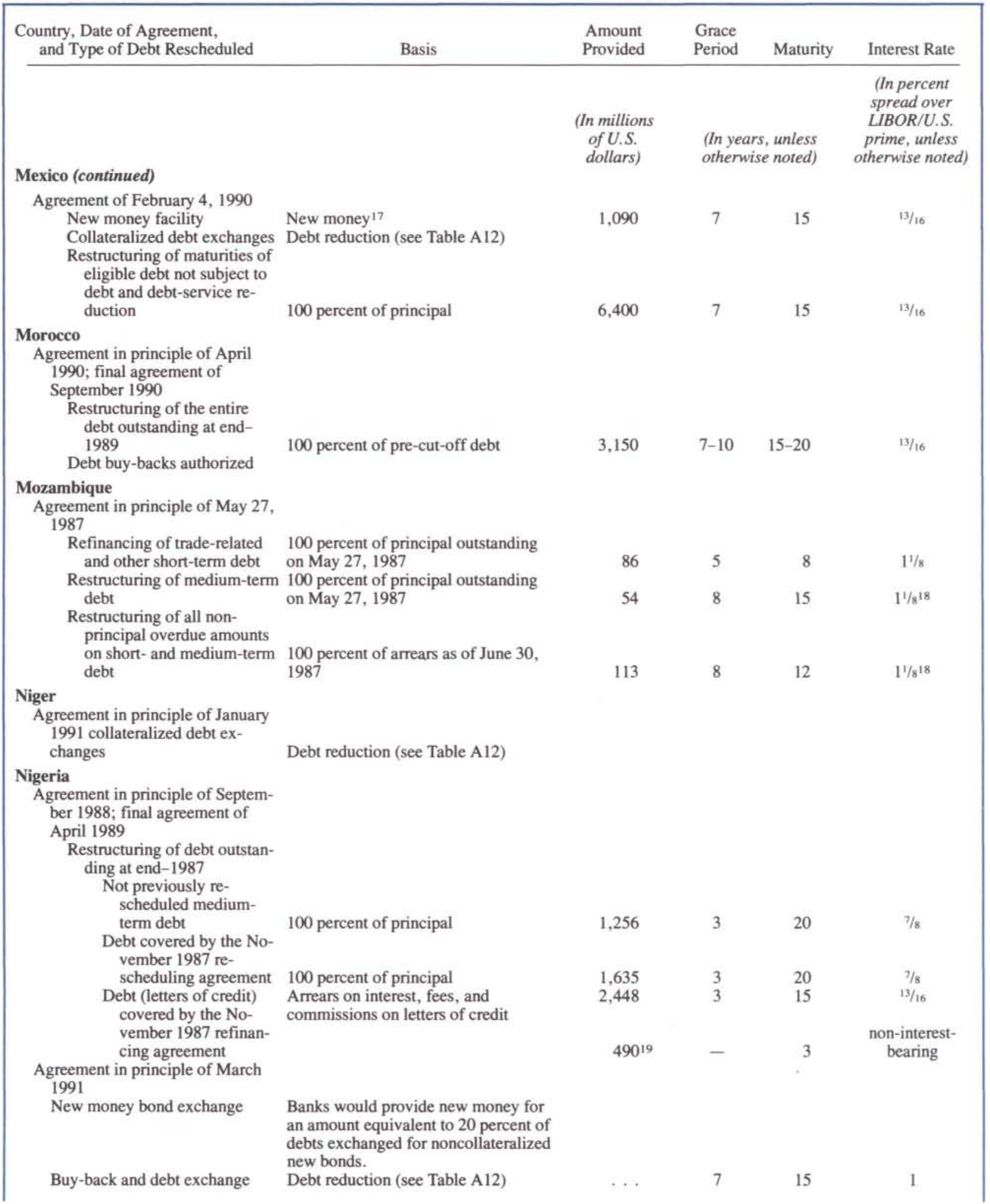


Table A14 (continued).

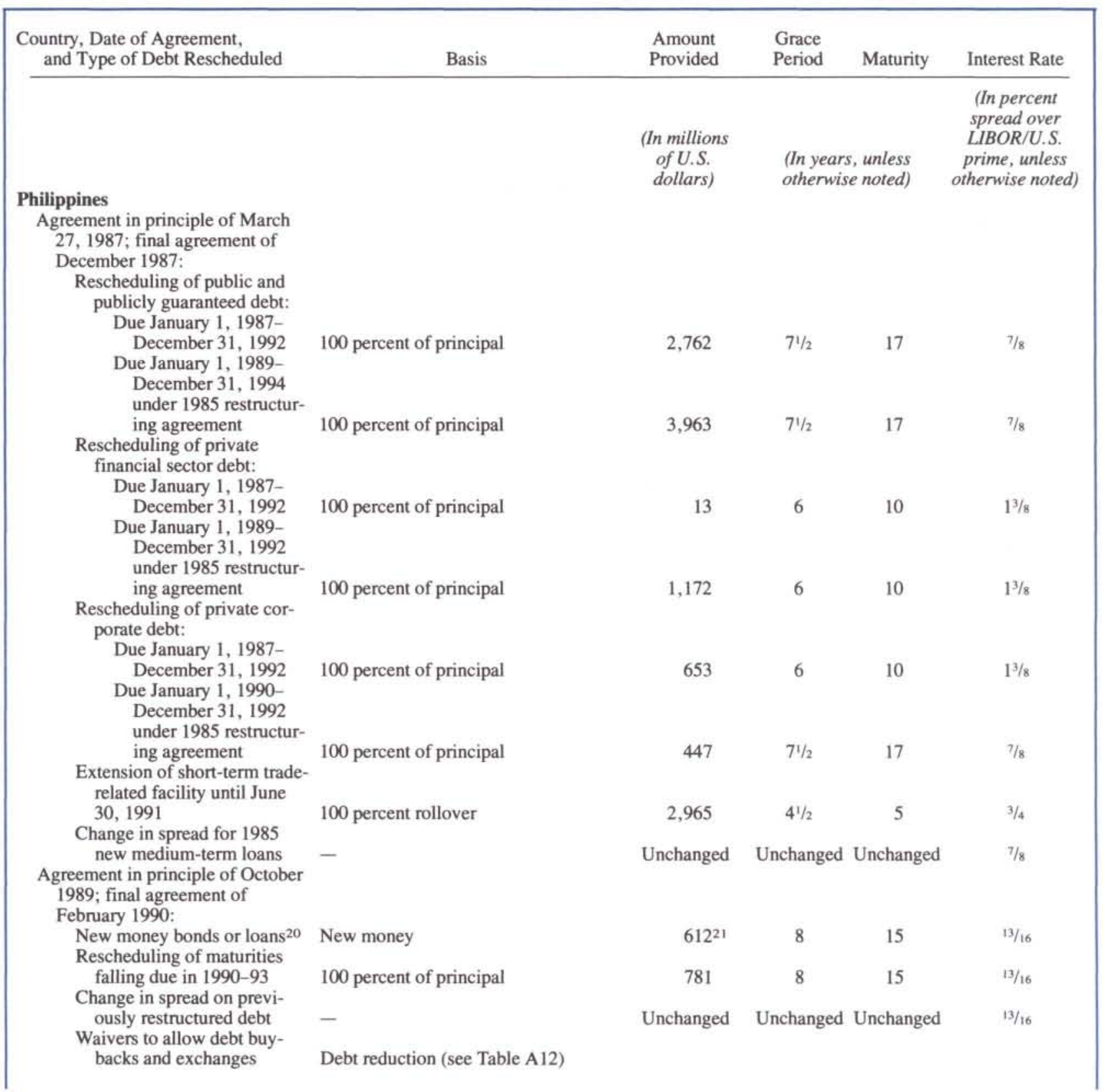


Table A14 (continued).

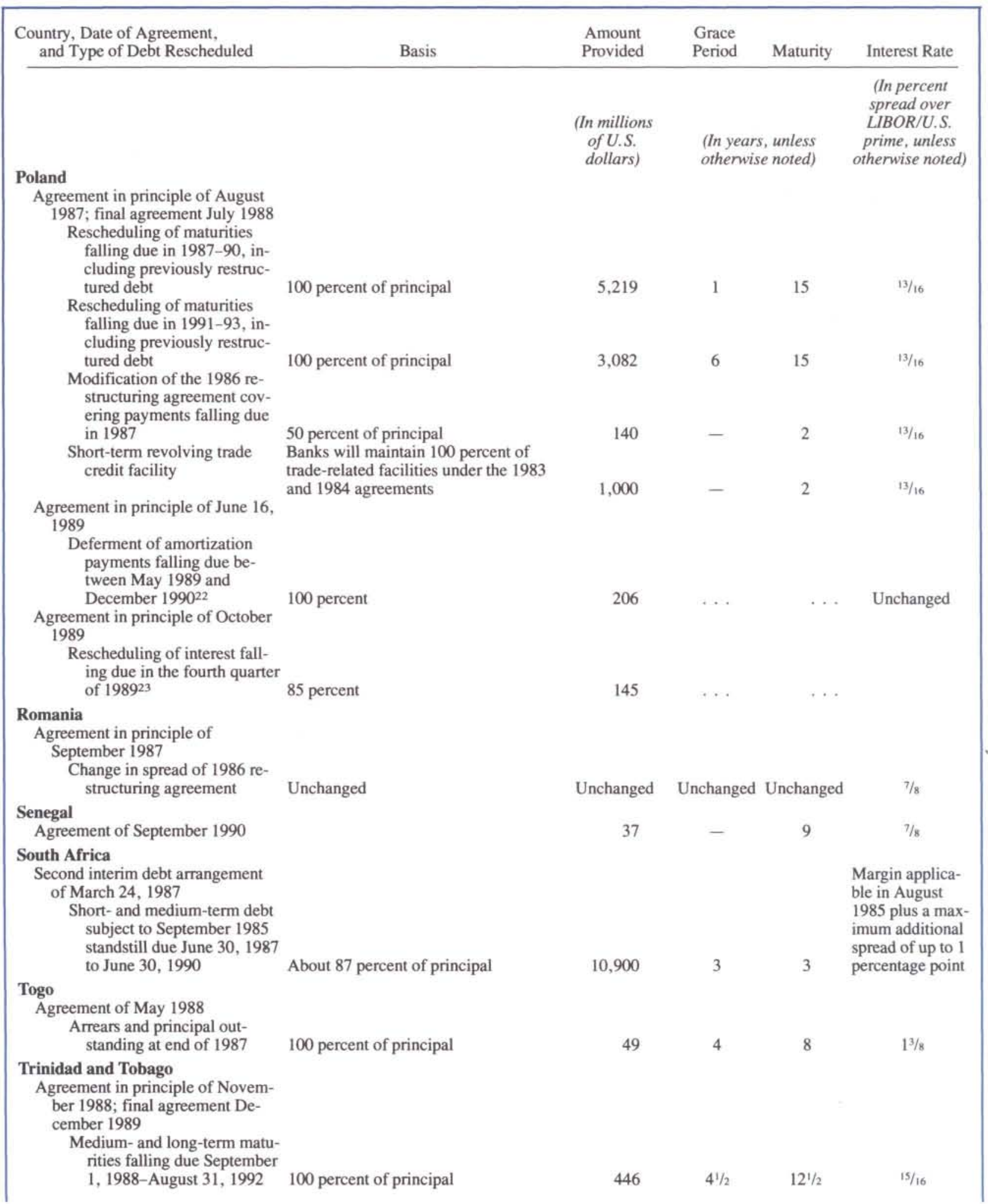




\section{Table A14 (continued).}

\begin{tabular}{|c|c|c|c|c|c|}
\hline \multirow[t]{2}{*}{$\begin{array}{l}\text { Country, Date of Agreement, } \\
\text { and Type of Debt Rescheduled }\end{array}$} & Basis & $\begin{array}{l}\text { Amount } \\
\text { Provided }\end{array}$ & $\begin{array}{l}\text { Grace } \\
\text { Period }\end{array}$ & Maturity & Interest Rate \\
\hline & & $\begin{array}{l}\text { (In millions } \\
\text { of U.S. } \\
\text { dollars) }\end{array}$ & $\begin{array}{l}\text { (In ye, } \\
\text { other }\end{array}$ & , unless & $\begin{array}{l}\text { (In percent } \\
\text { spread over } \\
\text { LIBOR/U.S. } \\
\text { prime, unless } \\
\text { otherwise noted) }\end{array}$ \\
\hline \multicolumn{6}{|l|}{ Uruguay } \\
\hline \multicolumn{6}{|l|}{$\begin{array}{l}\text { Agreement in principle of Novem- } \\
\text { ber 1987; final agreement March } \\
1988\end{array}$} \\
\hline \multicolumn{6}{|l|}{$\begin{array}{l}\text { Restructuring of maturities } \\
\text { falling due in } 1990-91 \text {, }\end{array}$} \\
\hline \multicolumn{6}{|l|}{$\begin{array}{l}\text { Agreement in principle of Novem- } \\
\text { ber 1990; final agreement Janu- } \\
\text { ary 1991 }\end{array}$} \\
\hline New Money Bond Exchange & $\begin{array}{l}20 \text { percent increase in exposure via } \\
\text { purchase of new bonds would entitle } \\
\text { banks to exchange at par old debt for } \\
\text { noncollateralized "debt conversion }\end{array}$ & & & & \\
\hline Buy-back and debt exchange & $\begin{array}{l}\text { notes." } \\
\text { Debt reduction (see Table A12) }\end{array}$ & 89 & 7 & 15 & 1.0 \\
\hline \multicolumn{6}{|l|}{ Venezuela } \\
\hline \multicolumn{6}{|l|}{$\begin{array}{l}\text { Agreement with Steering Commit- } \\
\text { tee of February 27, 1987; final } \\
\text { agreement September 18, } 1988 \\
\text { Modification of February }\end{array}$} \\
\hline $\begin{array}{l}1986 \text { rescheduling agree- } \\
\text { ment } \\
\text { Agreement in principle of March } \\
\text { 20, 1990; final term sheet of } \\
\text { June 25, 1990; final agreement } \\
\text { of December 5, } 1990\end{array}$ & 100 percent of principal & 20,338 & - & 13 & $7 / 8$ \\
\hline New money bond exchange & $\begin{array}{l}\text { Old debt (equal to five times the new } \\
\text { money provided) to be exchanged at } \\
\text { par for new, noncollateralized bonds. }\end{array}$ & 1,212 & 7 & 15 & 1 and $7 / 8^{25}$ \\
\hline Collateralized debt exchanges & Debt reduction (see Table A12) & & & & \\
\hline \multicolumn{6}{|l|}{ Yugoslavia } \\
\hline $\begin{array}{l}\text { Tentative agreement with bank co- } \\
\text { ordinating committee of April } \\
\text { 20,1988; final agreement Sep- } \\
\text { tember } 21,1988 \\
\text { Rescheduling of the stock of } \\
\text { medium- and long-term }\end{array}$ & & & & & \\
\hline debt & 100 percent of principal & 6,895 & 5 & 18 & $13 / 16$ \\
\hline New trade deposit facility & New financing & 300 & 5 & 5 & $7 / 8$ \\
\hline
\end{tabular}


Table A14 (concluded).

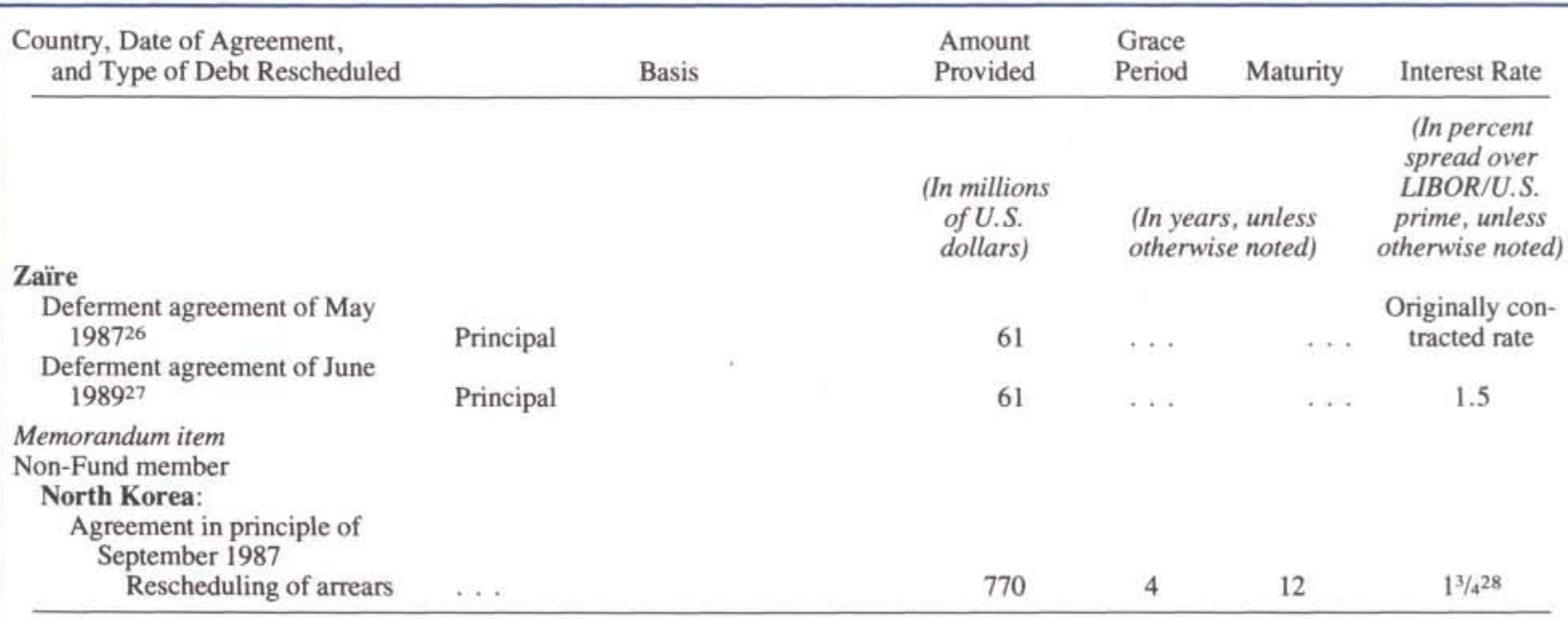

Sources: Restructuring agreements; and IMF staff estimates.

'Arrangements approved in principle before January 1, 1987 were reported in International Capital Markets: Developments and Prospects, World Economic and Financial Surveys (Washington: International Monetary Fund, April 1989).

${ }^{2}$ For public debt, pre-December 9, 1982, debt originally falling due prior to January 1, 1986, which has been previously restructured, and debt originally falling due after December 31,1985 , which has not been previously restructured. Excluded is indebtedness under the 1983 and 1985 term credit agreements and the 1985 trade credit and deposit facility, which is rescheduled on different terms. For private-sector borrowers, the restructuring of principal maturities of pre-December 9, 1982, indebtedness maturing subsequent to December 31,1985, including previously restructured maturities. Up to $\$ 5$ billion of eligible debt could be exchanged at par for 25 -year exit bonds carrying a fixed 4 percent yield.

${ }^{3}$ The agreement provides also for repricing and retiming of public sector debt. The savings to Brazil from repricing, which will consist of a reduction in the spread over the London interbank offered rate (LIBOR) from their current range (1.125-2.414) to 13/16, are estimated at $\$ 100$ million in 1988 and $\$ 380$ million in 1989. Retiming of interest periods from a quarterly to a six-monthly basis is estimated to provide relief of $\$ 600$ million in 1988 .

${ }^{4}$ Excluding (1) about $\$ 1$ billion corresponding to repayments on voluntary lending after January 1, 1983 falling due in 1988-93; and (2) amounts under switching operations (see footnote 6). Up to $\$ 5$ billion of eligible debt could be exchanged at par for 25 -year exit bonds carrying 6 percent fixed yield.

Includes at least $\$ 2,850$ million in parallel financing with the World Bank; two cofinancing facilities with the World Bank for up to $\$ 500$ million and $\$ 210$ million, respectively; and new money bonds for up to $\$ 1$ billion.

${ }^{6}$ Banks will be permitted to switch up to $\$ 1.8$ billion of interbank commitments to trade commitments during 1988-90.

TInterest periods under all agreements were temporarily converted to periods of 12 months providing relief in 1988 of an estimated \$415 million.

${ }^{8}$ Amendments also allow for repayments in Chilean currency and the pledge of collaterals to facilitate debt reduction, hedging operations, and the raising of voluntary new money. New money may be collateralized in amounts of up to $\$ 100$ million in $1988, \$ 200$ million in 1989 , and $\$ 200$ million a year, thereafter, with an aggregate limit of $\$ 500$ million outstanding at any point after 1989 . No more than $\$ 200$ million of new money can be collateralized with exportable assets. The limit on collateral for risk-management techniques is $\$ 150$ million.

"Spreads and guarantee fees would revert to their previous levels should Chile ask for new money "on a concerted basis" before the end of 1989.

${ }^{10}$ Amendments to the 1985 new money agreement also allow for an increase, as of January 1, 1989, of $\$ 35$ million in relending. To facilitate the reduction in spreads, the fee paid by banks on the World Bank guarantee, under the 1985 cofinancing agreement, was reduced by $1 / 4$ of 1 percentage point.

"The amendments provide for an extension of the retiming periods during which annual interest periods, which had been scheduled to revert to sixmonth interest periods, will be maintained. The extension will be until 1993 for 1985 new money; until 1994 for 1983 and 1984 new money; until 1995 for the 1983-84 restructuring agreements; and until 1996 for the 1985-91 restructuring agreements.

${ }^{12}$ Voluntary amortization payments made during the grace period would be matched on a 1:1 basis by debt forgiveness (equivalent to a buy-back option at 50 cents on the dollar).

${ }_{13}^{13}$ Interest rate would be increased by a maximum of 3 percentage points if GDP growth exceeds a threshold rate.

${ }^{14}$ Seventy percent of these arrears to be forgiven in 1990 upon downpayment equal to 5 percent of these arrears. Beginning at the end of 1990 and provided that Honduras remains current on interest due on all rescheduled amounts under the agreement, the creditor bank would further forgive interest arrears by a yearly amount equal to 5 percent of the arrears outstanding at end-October 1989 .

${ }^{15}$ Amount of debt on which terms were modified is not known because repayments made during 1985-87 have not been identified.

${ }^{16}$ Amortization of rescheduled amounts subject to relending at the choice of creditors, but within certain limits of the domestic credit program established by the Mexican authorities.

${ }^{17} \mathrm{New}$ money options include medium-term loan, new money bonds, on-lending facility, and medium-term trade facility.

${ }_{18}$ Spread to increase to $1 \frac{1}{4}$ percentage points at the end of the grace period.

${ }^{19}$ Includes $\$ 112$ million of previously capitalized interest arrears on letters of credit.

${ }^{20} \mathrm{Allowance}$ for re-lending for up to 366 days of up to 20 percent of the new money on a revolving basis, of which one half would be available in any one calendar year and one half would be available to the private sector.

${ }^{21}$ As of end-December 1989.

${ }^{22}$ Payment is to be deferred until December 30, 1991. Alternatively, banks may receive payments according to the original schedule in return for an equal increase in the short-term revolving trade facility.

${ }^{23}$ Payment was deferred until the second quarter of 1990.

${ }^{24} \mathrm{Net}$ of $\$ 24$ million of prepayment required under the agreement.

${ }^{25}$ The interest rate of LIBOR plus $7 / 8$ applies to the new money bonds issued by the Central Bank (as opposed to the Republic of Venezuela).

${ }^{26}$ There will be monthly payments of $\$ 3$ million for the May 1987-May 1988 period, except for July 1987 when the payment due is $\$ 3.5$ million.

${ }^{27}$ Under this agreement Zaîre would make monthly payments of \$4 million, which roughly covers interest on outstanding claims (including principal and interest arrears).

${ }^{28}$ The spread over LIBOR is expected to remain $1^{3 / 4}$ percentage points for the first three years, to decline to $1^{1 / 2}$ percentage points for the next five years, and to $1 \frac{1}{4}$ percentage points for the final four years, subject to the borrowers' compliance with the terms and conditions of the agreement. 


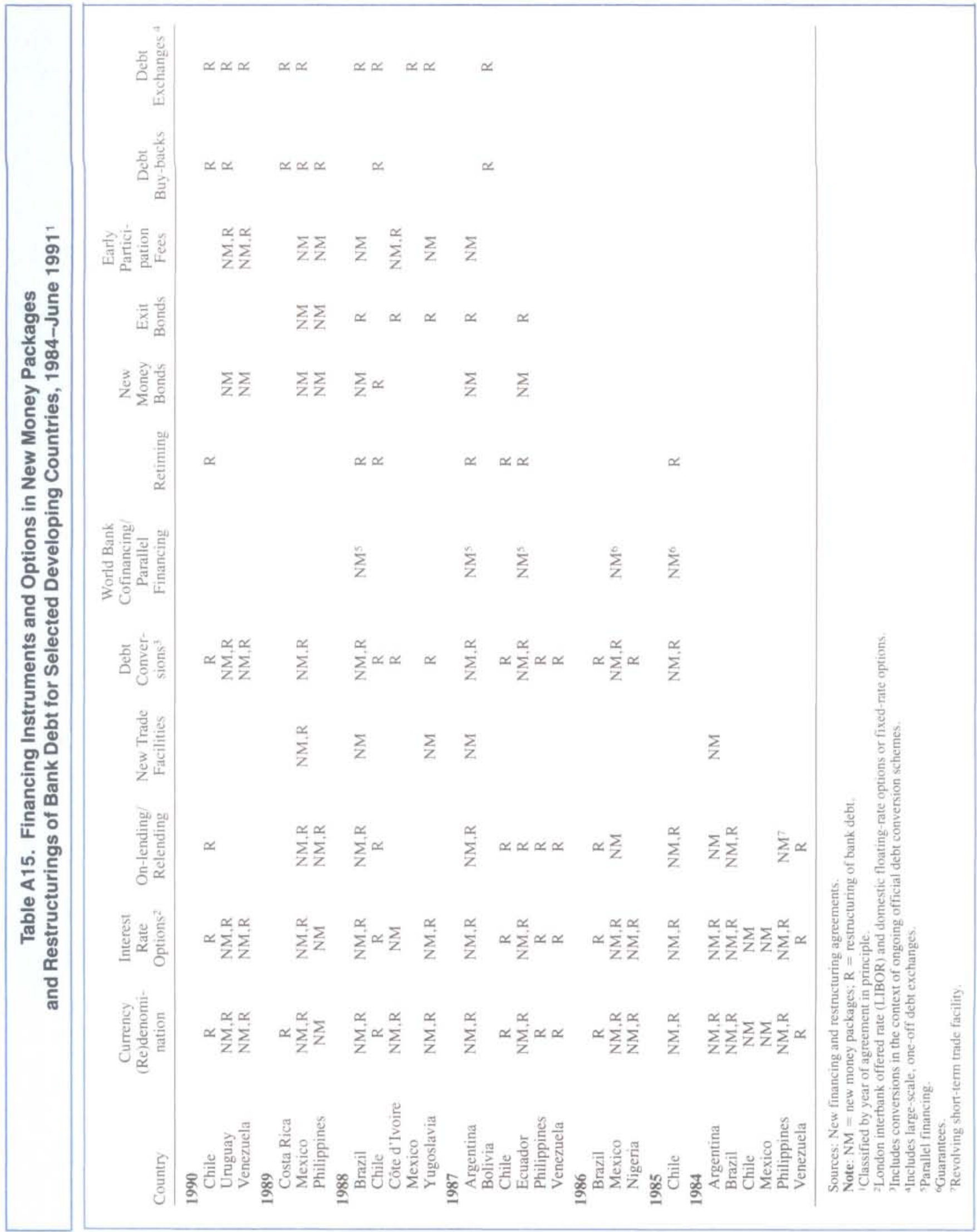




\section{Table A16. Features of Selected Debt Conversion Schemes}

Costa

Philip-

Vene-

Argentina Brazil' Chile Rica Ecuador ${ }^{2}$ Honduras Jamaica Mexico Nigeria pines Uruguay zuela

Eligible investors

Nonresidents

Any creditor

Original creditor only

Residents

Eligible external debt

Public sector

Private sector

Exchange rate for

$$
\text { conversion }
$$

Official exchange rate

Parallel exchange rates

Valuation of debt for conversion

Face value

Below face value

Eligible domestic

investments

Equity

Parastatal enterprises

Private companies

Original obligor only

Debt

Public sector

Private sector

Repayment of domestic obligations

Restrictions on eligible investments

Restrictions on capital repatriations

Restrictions on profit remittances

Same as for all

foreign investment

More restrictive

than the above

\begin{tabular}{|c|c|c|c|c|c|c|c|c|c|c|}
\hline$x$ & $x$ & $x$ & $\mathrm{x}$ & $x$ & $x$ & $\mathrm{x}$ & $x$ & $\mathrm{x}$ & $x$ & $\mathbf{x}$ \\
\hline$x$ & & $x$ & $x$ & $x$ & $x$ & & $\mathrm{x}$ & & $x$ & $\mathrm{x}$ \\
\hline$x$ & $x$ & $x$ & $\mathrm{x}$ & $x$ & $\mathrm{x}$ & $x^{4}$ & $\mathrm{x}$ & $x^{5}$ & $\mathrm{x}$ & $\mathrm{x}$ \\
\hline$x$ & $x$ & $\mathrm{x}$ & & & & & & & $\mathrm{x}$ & \\
\hline
\end{tabular}

$\begin{array}{llllllllllll}\mathrm{x}^{6} & \mathrm{x} & \mathrm{x} & \mathrm{x} & \mathrm{x} & \mathrm{x} & \mathrm{x} & \mathrm{x} & \mathrm{x} & \mathrm{x} & \mathrm{x} & \\ \end{array}$

$\begin{array}{lllllllllll} & \mathrm{x}^{7} & \mathrm{x} & \mathrm{x}^{10} & \mathrm{x} & \mathrm{x} & \mathrm{x}^{8} & \mathrm{x} & & \mathrm{x}^{9} & \\ \mathrm{x}^{8} & & \mathrm{x}^{3} & \mathrm{x}^{11} & \mathrm{x} & \mathrm{x} & \mathrm{x}\end{array}$

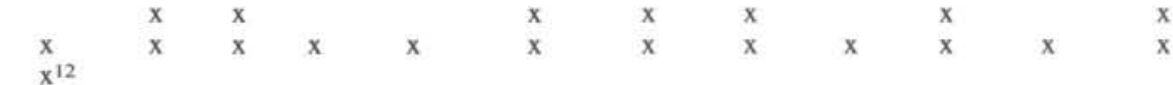

$\mathrm{x}^{13} \quad \mathrm{x} \quad \mathrm{x}-\mathrm{x}$

$\mathrm{x} \quad \mathrm{x}$ 
Table A16 (concluded).

Costa

Philip-

Argentina Brazil' Chile Rica Ecuador ${ }^{2}$ Honduras Jamaica Mexico Nigeria pines Uruguay zuela

Other features

Limit on value of conversions

Auction system

Conversion fees

Additional foreign

exchange required

$\begin{array}{llll}\mathrm{X} & \mathrm{x} & \mathrm{x} & \mathrm{X} \\ \mathrm{x} & \mathrm{X} & \mathrm{x}^{14} & \end{array}$

$\begin{array}{lll}x & x & x \\ x & x & x^{14}\end{array}$

X

$\begin{array}{lllllll}x & x & x & x & x & x^{15} & x \\ x & x & x & x & x & & x \\ x^{16} & & x & & \end{array}$

$x^{17}$

Sources: Argentina, 1987 Refinancing Plan; Brazil, Foreign Investment Law (Law No. 4.131 and Decree No. 55.762), Central Bank of Brazil, Resolution 1460, February 1, 1988; Central Bank of Chile, Compendium of Rules on International Exchange, Chapters XVIII and XIX, and Decree Law 600; Central Bank of Costa Rica, A Guide for Converting Foreign Debt Securities Issued by the Central Bank of Costa Rica into Colones; Central Bank of Ecuador, Monetary Board Circular Nos. 395-86 and 408-87; Mexico, National Commission on Foreign Investment, Manual Operativo para la Capitalizacion de Pasivos y Sustitucion de Deuda Publica por Inversion; Central Bank of Philippines, Revised Circular No. 1111; Venezuela, Office of the President of the Republic. Decrees Nos. 1259 (Nov. 15, 1990) and 1418 (Dec. 27, 1990), and Central Bank Resolution 89-8-04 of August 31, 1989, and Ministry of Finance Resolution 2401 of September 4, 1989; Central Bank of Honduras Circular D-036/89, July 6, 1989; Central Bank of Unuguay, Disposicion del 8 Diciembre 1987; Bank of Jamaica, Programme for the Conversion of Jamaican External Debt into Equity Investments, July 1987; Nigeria Guidelines on Debt Conversion Program for Nigeria, July 5, 1988 and 1988 Rescheduling Proposal.

'In November 1987, the authorities announced a new debt-equity swap scheme. The description in this table corresponds to this scheme.

${ }^{2}$ Introduced in February 1987 and temporarily suspended in August 1987.

${ }^{3} \mathrm{~A}$ minimum discount of 35 percent applies.

${ }^{4}$ Debt rescheduled under the A tranche of the June 1990 rescheduling agreement with commercial banks.

SRescheduled debt only.

${ }^{6}$ Free-market exchange rate.

TThe June 1988 rescheduling agreement allows for conversion of exit bonds and new money at face value.

${ }^{8}$ Depends on type of investment and on discount in secondary market.

${ }^{9}$ Applies to debt-bond conversions.

${ }^{10}$ Conversions of public-sector debt are subject to a small discount; conversion terms of private-sector debt are negotiable.

"Applies to debt-equity conversions.

${ }^{12}$ Private-sector debt only.

${ }^{13}$ Exit bonds can be exchanged for Treasury securities.

${ }^{14}$ Chapter XVIII investments only.

${ }^{15}$ Conversion rights will be administratively allocated if the offers tendered for debt conversion exceed the established annual limit.

${ }^{16} \mathrm{~A}$ fee not exceeding 10 percent of the face value, depending on priority of investment.

${ }^{17}$ Fees depend on the share of investment funded with foreign exchange. 


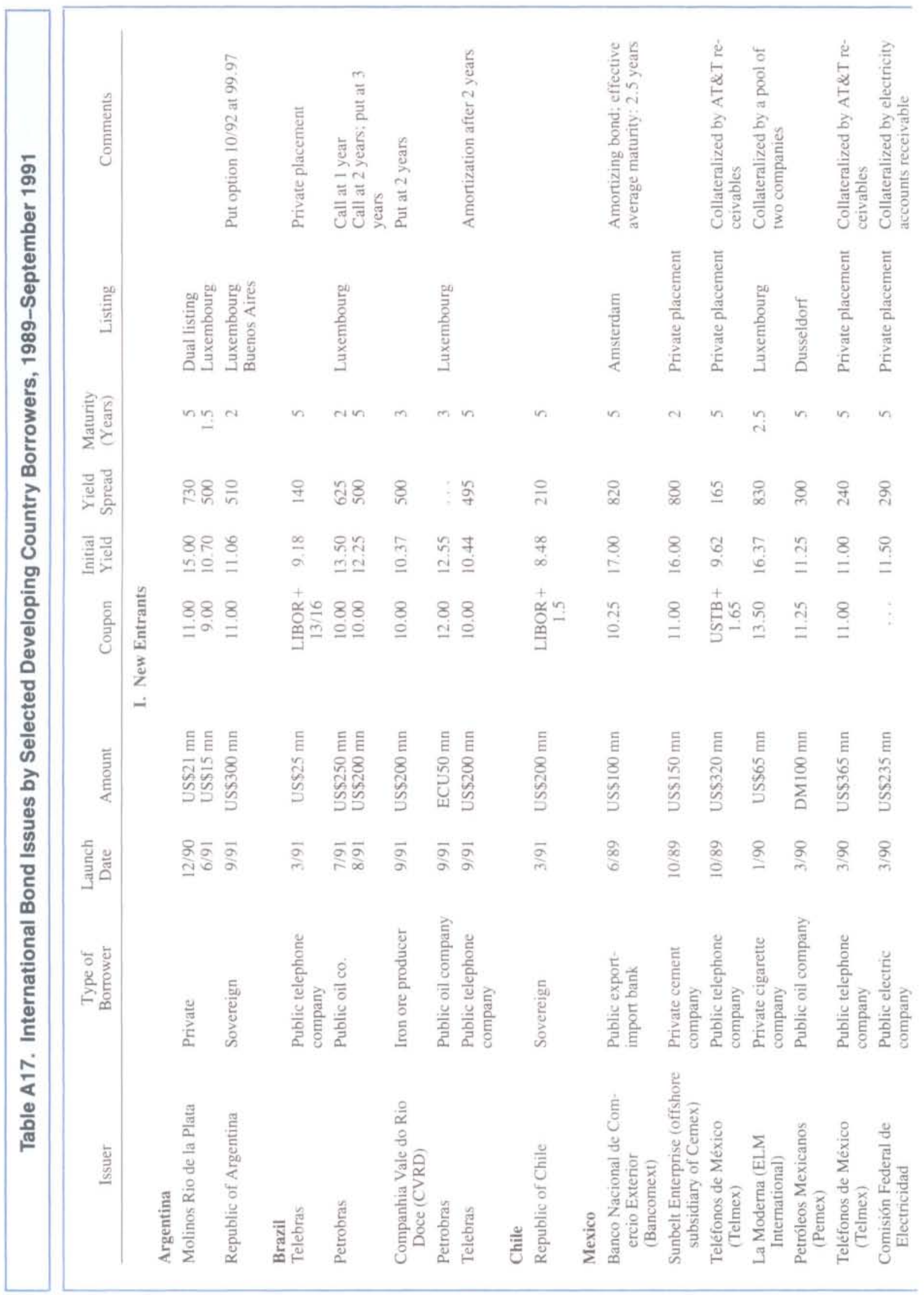




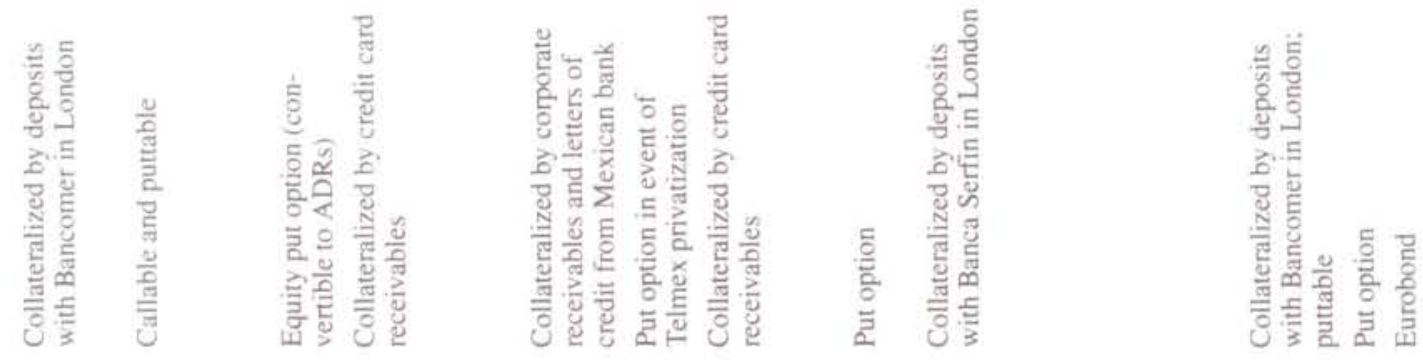

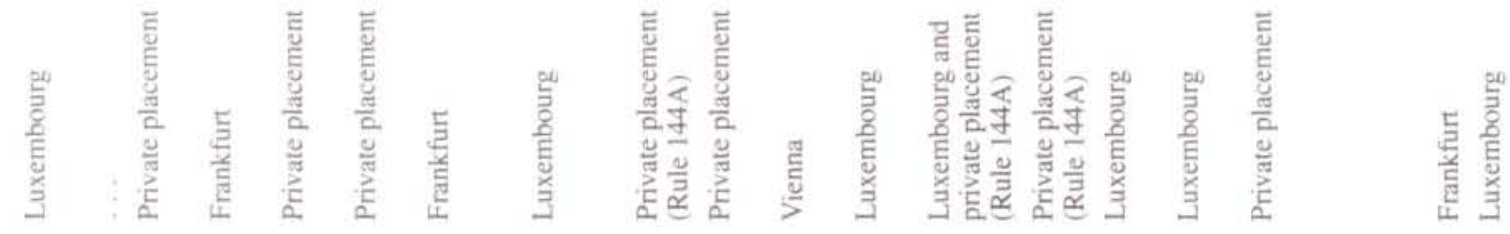

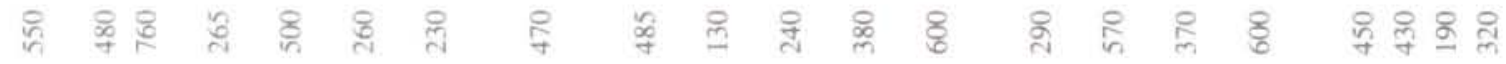

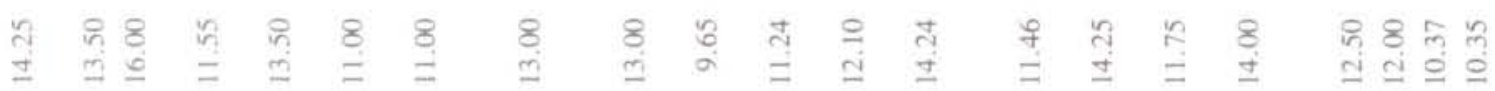



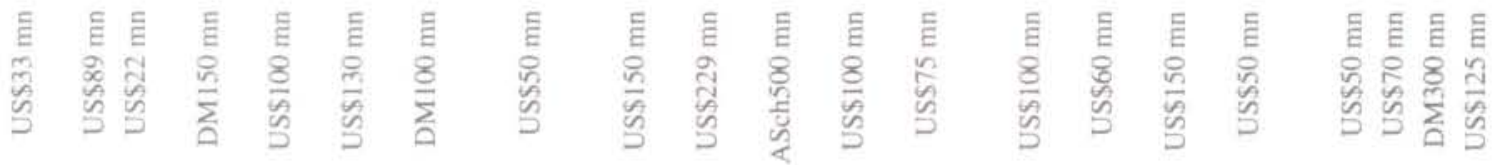

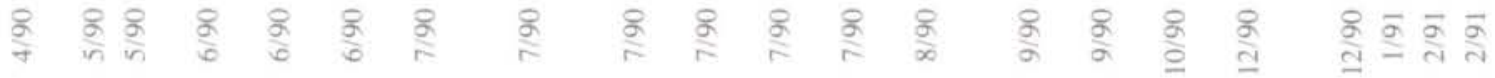

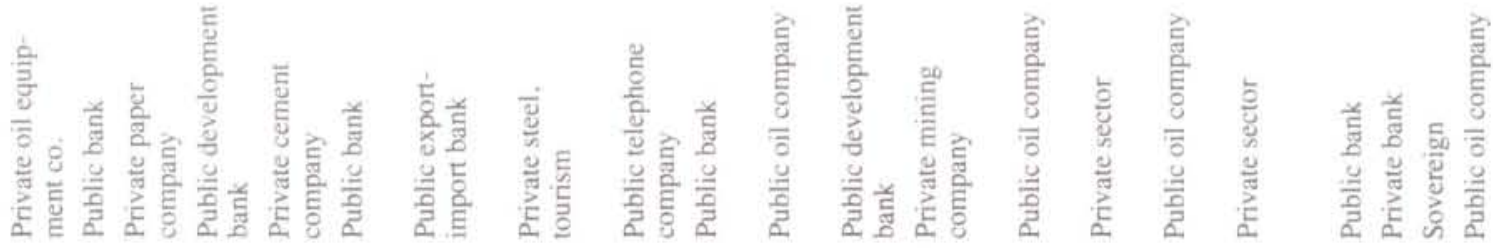

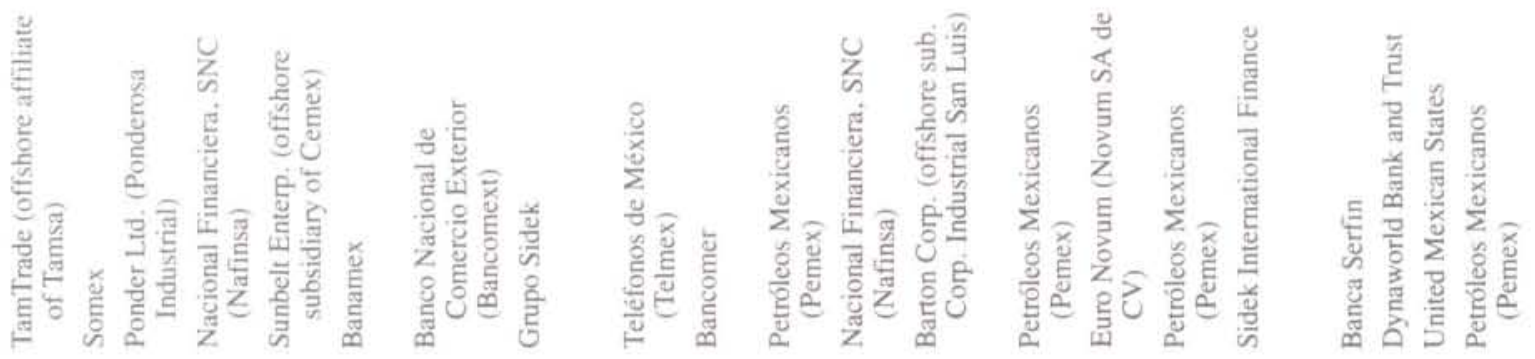









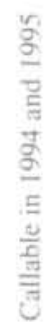

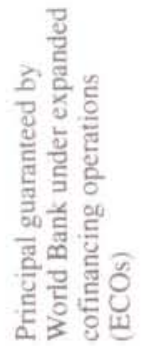

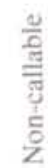

点点点
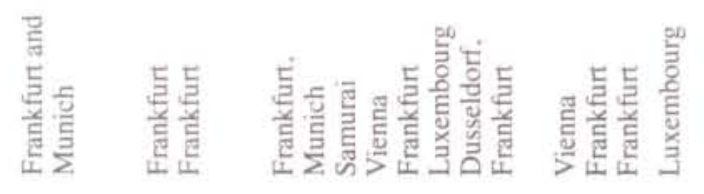

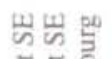

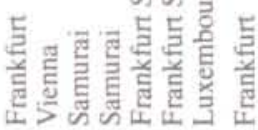

in $r$ ormarrag

nonmingn

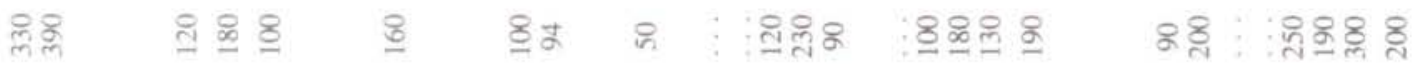

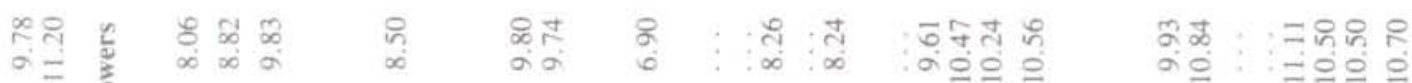

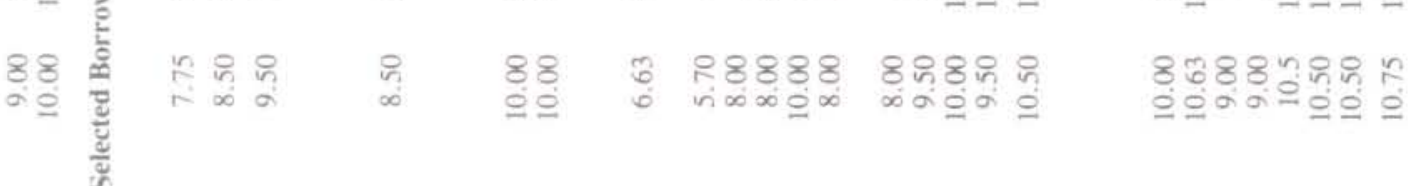

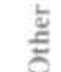

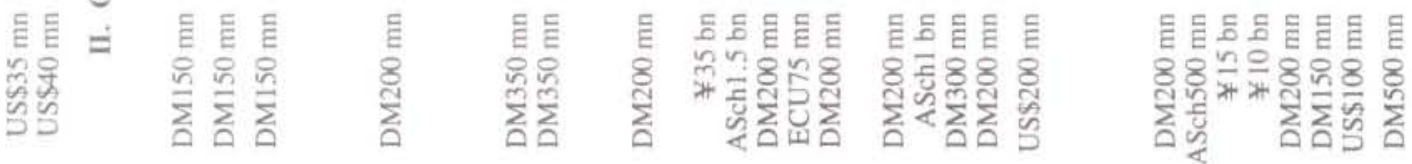

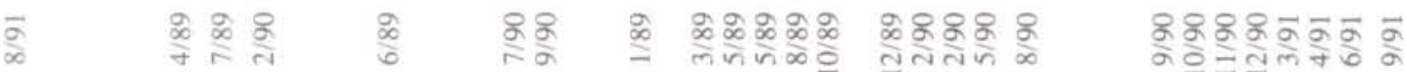

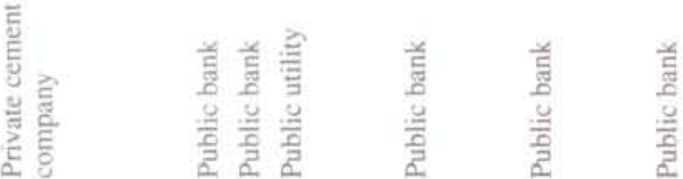
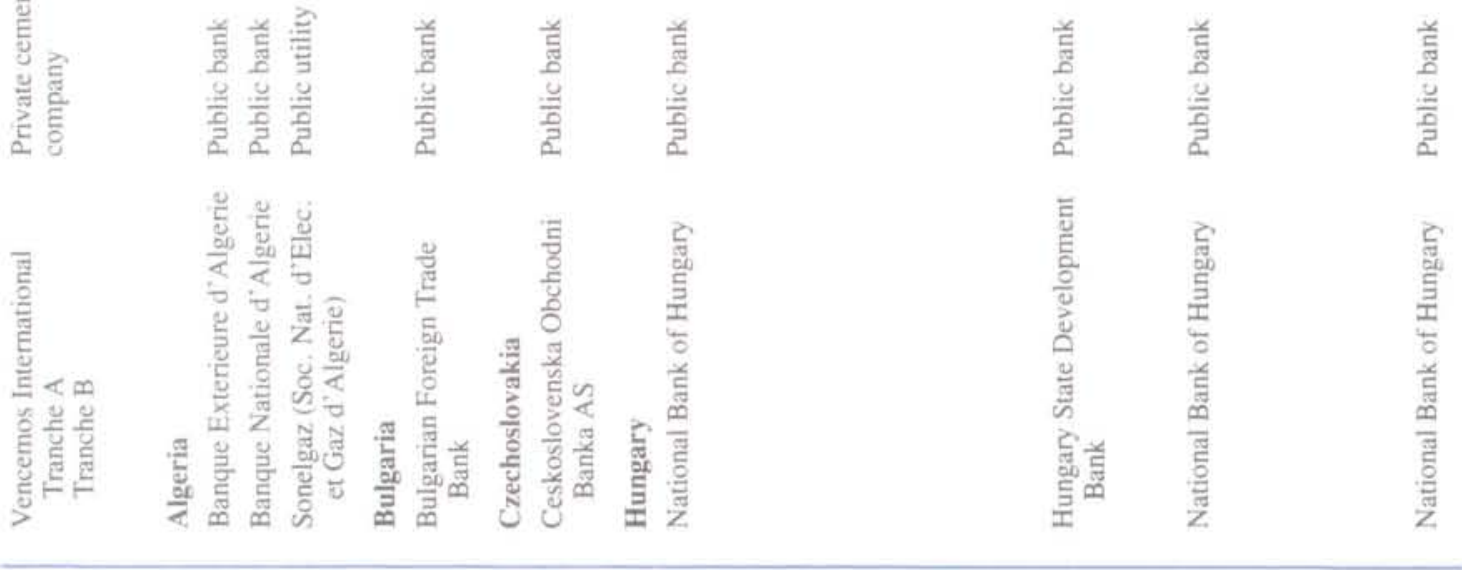


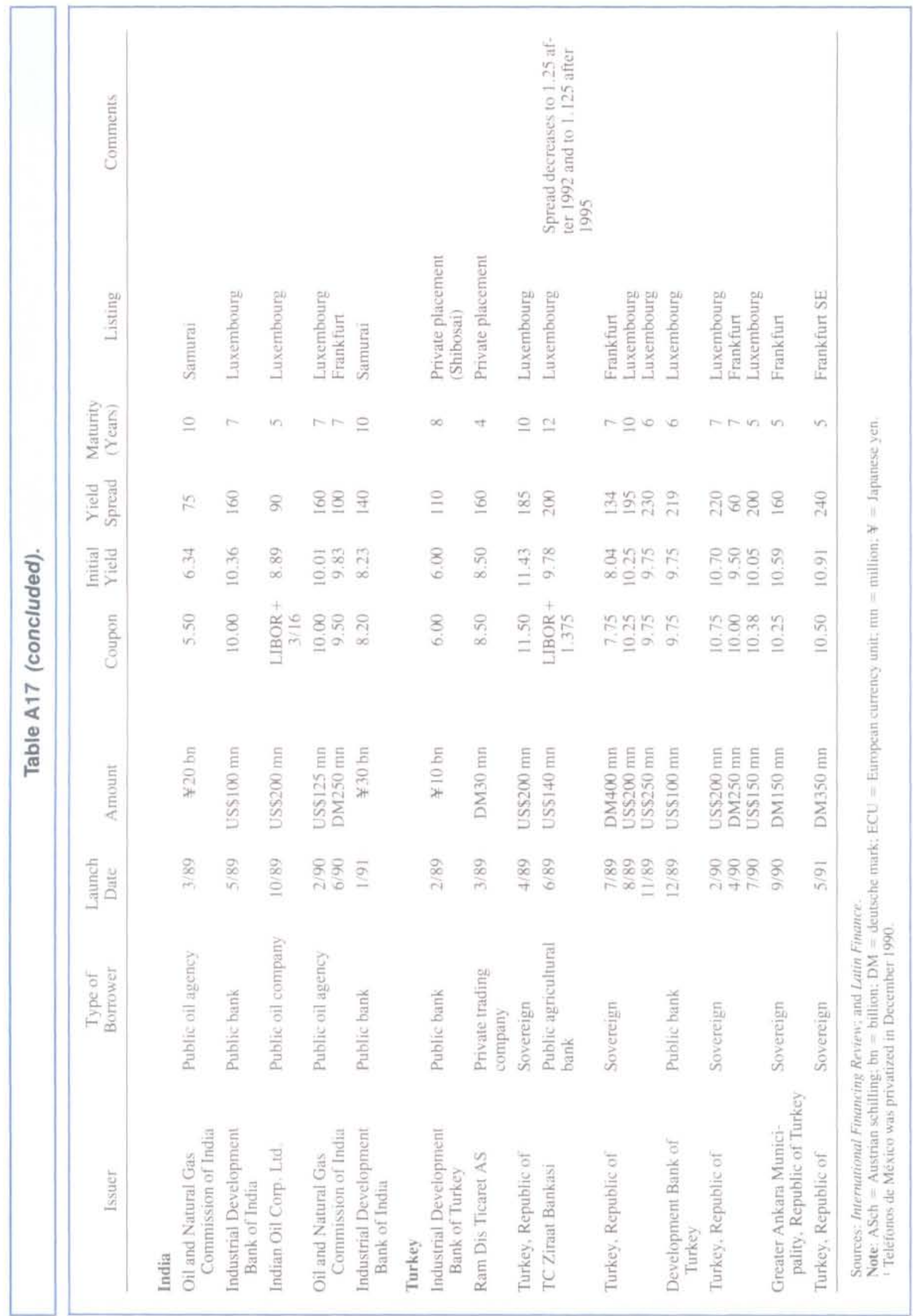

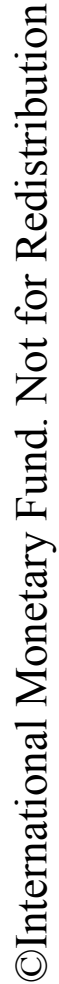




\section{References}

Brewer, Thomas L., "Foreign Direct Investment in Developing Countries," World Bank Working Papers, WPS 712 (Washington: World Bank, June 1991).

Chartered West LB Ltd, "Confidence and Capital Repatriation in Latin America," Developing Country Investment Review (March 1991), pp. 2-4.

Cockcroft, Laurence, and Roger C. Riddell, "Foreign Direct Investment in Sub-Saharan Africa," World Bank Working Papers, WPS 619 (Washington: World Bank, 1991).

Conesa, Eduardo R., "The Causes of Capital Flight from Latin America" (mimeographed, Washington: InterAmerican Development Bank, 1986).

Cuddington, John T., "Capital Flight: Estimates, Issues and Explanations," Princeton Studies in International Finance, No. 58 (Princeton, New Jersey: 1986).

Cumby, Robert, and Richard Levich, "On the Definition and Magnitude of Recent Capital Flight," in Capital Flight and Third World Debt, ed. by Donald R. Lessard, and John Williamson (Washington: Institute for International Economics, 1987).

Deppler, Michael, and Martin Williamson, "Capital Flight: Concepts, Measurement and Issues," Staff Studies for the World Economic Outlook (Washington: International Monetary Fund, September 1987), pp. 422-36.

Dooley, Michael P., "Capital Flight: A Response to Differences in Financial Risks," Staff Papers, Vol. 35 (Washington: International Monetary Fund, September 1988).

Dornbusch, Rudiger, "Capital Flight: Theory, Measurement and Policy Issues," Occasional Papers, No. 1 (Washington: Inter-American Development Bank, 1991).

Dodsworth, John, Mohamed A. El-Erian, and D. Hamman, "Foreign Currency Deposits in Developing Countries-Origins and Economic Implications," IMF Working Paper, WP/87/12 (Washington: International Monetary Fund, March 1987).

El-Erian, Mohamed A., "Currency Substitution in Egypt and the Yemen Arab Republic," Staff Papers, Vol. 35 (Washington: International Monetary Fund, March 1988), pp. 85-103.

(1991a), "The Restoration of Latin America's Access to Voluntary Capital Market FinancingDevelopments and Prospects," IMF Working Paper, WP/91/74 (Washington: International Monetary Fund, August 1991).

(1991b), "Mexico's External Debt and the Return to Voluntary Capital Market Financing," IMF Working Paper, WP/91/82 (Washington: International Monetary Fund, August 1991).

Fischer, Stanley, "Seigniorage and the Case for a National Money," Journal of Political Economy (Chicago: April 1987).
Gordon, David B., and Ross Levine, "The 'Problem' of Capital Flight: A Cautionary Note," World Economy. Vol. 12 (June 1989).

Inotai A., "Liberalization and Foreign Direct Investment," Foreign Economic Liberalization, A. Koves, and P. Moreur, eds., Westview Press (1991), pp. 99-112.

Internal Revenue Service, U.S. Department of the Treasury, "Study of Tax Amnesty Programs" (Washington: August 1987).

International Monetary Fund (1990a), International Capital Markets: Developments and Prospects, World Economic and Financial Surveys (Washington: International Monetary Fund, May 1990).

(1991), International Capital Markets: Developments and Prospects, World Economic and Financial Surveys (Washington: International Monetary Fund, May 1991).

Kahn, Moshin, and Nadeem Ul Haque, "Foreign Borrowing and Capital Flight: A Formal Analysis," Staff Papers, Vol. 32 (Washington: International Monetary Fund, December 1985).

Kletzner, Kenneth, "Asymmetries of Information and LDC Borrowing with Sovereign Risk," Economic Journal (Cambridge, England: June 1984), pp. 287-307.

Lessard, Donald R., and John Williamson, Capital Flight: The Problem and Policy Responses, Washington Institute for International Economics (Washington: November 1987).

Leonard, Herman B., and Richard J. Zeckhauser, "Amnesty, Enforcement and Tax Policy," NBER Working Paper No. 2096 (Cambridge: National Bureau of Economic Research, December 1986).

Mathieson, Donald J., and others, Managing Financial Risks in Indebted Developing Countries, IMF Occasional Paper No. 65 (Washington: International Monetary Fund, June 1989).

Meyer A., and M.S. Bastos-Márques, "A Fuga de Capital no Brazil," Fundaçao Getulio Vargas, Institute Brasileiro de Economia, Centro de Estudios Monetarios e de Economia Internacional, No. 06/89 (August 1989).

Morgan Guaranty Trust Company, "LDC Capital Flight," World Financial Markets (New York: March 1986), pp. 13-15.

Ortiz, Guillermo, "Dollarization in Mexico: Causes and Consequences," Financial Policies and the World Capital Market: The Case of Latin America, P. Aspe and others, eds. (Chicago: University of Chicago Press, 1983).

Ramírez-Rojas, C., "Currency Substitution in Argentina, Mexico and Uruguay," Staff Papers, Vol. 32 (Washington: International Monetary Fund, December 1985), pp. 624-67. 
Rojas-Suárez, Liliana, "Risk and Capital Flight in Developing Countries," Determinants and Systemic Consequences of International Capital Flows, IMF Occasional Paper No. 77 (Washington: International Monetary Fund, March 1991).

Stella, Peter, "An Economic Analysis of Tax Amnesties," IMF Working Paper, WP/89/42 (Washington: International Monetary Fund, May 1989).

Stiglitz, J.E., and A. Weiss, "Credit Rationing in Markets with Imperfect Information," American Economic Re- view, Vol. 71 (Nashville, Tennessee: June 1981).

Uchitelle, Elliott, "The Effectiveness of Tax Amnesty Programs in Selected Countries," FRBNY Quarterly Review (New York: Federal Reserve Bank of New York, Autumn 1989).

Wallace, Cynthia Day, ed., Foreign Direct Investment in the 1990s (Netherlands: Martnus Nijhoff Publisher, 1990).

World Bank, World Development Report (New York: Oxford University Press, 1985). 
January 1988

February 1988

April 1988

May 1988

May 1988

July 1988

October 1988

April 1989

April 1989

July 1989

August 1989

September 1989

October 1989

April 1990

May 1990

May 1990

July 1990

September 1990

October 1990

November 1990

May 1991

May 1991

October 1991

December 1991
International Capital Markets: Developments and Prospects, by Maxwell Watson, Donald Mathieson, Russell Kincaid, David Folkerts-Landau, Klaus Regling, and Caroline Atkinson.

Officially Supported Export Credits: Developments and Prospects, by K. Burke Dillon and Luis Duran-Downing, with Miranda Xafa.

World Economic Outlook: A Survey by the Staff of the International Monetary Fund.

Multilateral Official Debt Rescheduling: Recent Experience, by Peter M. Keller, with Nissanke E. Weerasinghe.

Primary Commodities: Market Developments and Outlook, by the Commodities Division of the Research Department.

Staff Studies for the World Economic Outlook, by the Research Department of the International Monetary Fund.

World Economic Outlook: Revised Projections, by the Staff of the International Monetary Fund.

World Economic Outlook: A Survey by the Staff of the International Monetary Fund.

International Capital Markets: Developments and Prospects, by a Staff Team from the Exchange and Trade Relations and Research Departments.

Primary Commodities: Market Developments and Outlook, by the Commodities Division of the Research Department.

Staff Studies for the World Economic Outlook, by the Research Department of the International Monetary Fund.

Developments in International Exchange and Trade Systems, by a Staff Team from the Exchange and Trade Relations Department.

World Economic Outlook: A Survey by the Staff of the International Monetary Fund.

International Capital Markets: Developments and Prospects, by a Staff Team from the Exchange and Trade Relations and Research Departments.

Officially Supported Export Credits: Developments and Prospects, by G.G. Johnson, Matthew Fisher, and Elliott Harris.

World Economic Outlook: A Survey by the Staff of the International Monetary Fund.

Primary Commodities: Market Developments and Outlook, by the Commodities Division of the Research Department.

Staff Studies for the World Economic Outlook, by the Research Department of the International Monetary Fund.

World Economic Outlook: A Survey by the Staff of the International Monetary Fund.

Multilateral Official Debt Rescheduling: Recent Experience, by Michael G. Kuhn with Jorge P. Guzman.

International Capital Markets: Developments and Prospects, by a Staff Team from the Exchange and Trade Relations and Research Departments.

World Economic Outlook: A Survey by the Staff of the International Monetary Fund.

World Economic Outlook: A Survey by the Staff of the International Monetary Fund.

Private Market Financing for Developing Countries, by a Staff Team from the Exchange and Trade Relations Department. 